\title{
Construção e validação de um instrumento voltado à satisfação do doador de sangue
}

\author{
Versão original
}

Tese apresentada à Faculdade de Medicina de Ribeirão Preto da Universidade de São Paulo para a obtenção do título de Doutora em Ciências.

Orientador: Prof. Dr. Edson Zangiacomi Martinez

Ribeirão Preto

2018 
Autorizo a reprodução e divulgação total ou parcial deste trabalho, por qualquer meio convencional ou eletrônico, para fins de estudo e pesquisa, desde que citada a fonte.

\section{FICHA CATALOGRÁFICA}

Trovão, Ana Carolina Garcia Braz

Construção e validação de um instrumento voltado à satisfação do doador de sangue.

Ribeirão Preto, 2018.

122 p.: il.; $30 \mathrm{~cm}$

Tese (Doutorado) apresentada à Faculdade de Medicina de Ribeirão Preto/USP. Área de concentração: Saúde na Comunidade.

Orientador: Edson Zangiacomi Martinez

1. Doadores de sangue. 2. Validação de instrumento. 3. Grupos focais. 4. Satisfação. 


\section{Folha de Aprovação}

Nome: Ana Carolina Garcia Braz

Construção e validação de um instrumento voltado à satisfação do doador de sangue

Tese apresentada à Faculdade de Medicina de Ribeirão Preto da Universidade de São Paulo para obtenção de título de Doutora.

Área de concentração: Saúde na Comunidade

Aprovada em:

Banca Examinadora

Prof. Dr.

Instituição:

Assinatura:

Prof. Dr.

Instituição:

Assinatura:

Prof. Dr.

Instituição:

Assinatura:

Prof. Dr.

Instituição:

Assinatura:

Prof. Dr.

Instituição:

Assinatura: 


\section{Agradecimentos}

À Faculdade de Medicina de Ribeirão Preto da Universidade de São Paulo.

Ao meu orientador Professor Doutor Edson Zangiacomi Martinez, por direcionar meus estudos, pela parceria de trabalhos há anos e por sempre me acolher, instruir e acreditar no meu potencial. Professor, obrigada por tudo!

À Fundação Hemocentro de Ribeirão Preto, por possibilitar a realização desta pesquisa.

À equipe do Núcleo de Hemoterapia de Franca em especial os colegas de trabalho e amigos Marco Benedetti, Teresinha Cervi, Gilda, Rosângela, Eliete, Ivone, Sônia, Angélica, Diva, Ivonete, Maria Inês, Vera Lúcia e Solange, por contribuírem diretamente com esta pesquisa, meu muito obrigada!

Ao Rui Akito Tamaribuchi, pelas valiosas sugestões durante a elaboração do instrumento de satisfação do doador de sangue. 


\section{Dedicatória}

Dedico este trabalho primeiramente a Deus, minha fortaleza e meu amparo na realização deste grande sonho.

Aos meus pais, Lourival e Maria, por serem meu estímulo na tribulação. Ao meu pequeno Theo, razão de minhas batalhas e conquistas. Ao meu esposo Jorge, por olharmos na mesma direção e me proporcionar a graça da partilha.

A toda minha família pelo apoio. 
"Sonhar o sonho impossível...

Sofrer a angústia implacável...

Pisar onde os bravos não ousam...

Reparar o mal irreparável...

Amar um amor casto à distância...

Enfrentar o inimigo invencível...

Tentar quando as forças se esvaem...

Alcançar a estrela inatingível...

Essa é minha busca."

Dom Quixote de La Mancha

(Miguel de Cervantes) 


\section{Resumo}

TROVÃO, A. C. G. B. Construção e validação de um instrumento voltado à satisfação do doador de sangue. Tese (doutorado) - Faculdade de Medicina de Ribeirão Preto - USP, Ribeirão Preto, SP, Brasil, 2018.

Em 2015, no Brasil, a taxa de doação de sangue para o país foi estimada pelo Ministério da Saúde em 18,2 doações por 1.000 habitantes, enquanto em 2014, esta taxa era 18,49. A manutenção dos estoques de sangue no país é um desafio constante nos serviços de hemoterapia e estratégias de captação e fidelização dos doadores são essenciais. Assim, é necessário conhecer as expectativas do doador em relação ao atendimento durante a doação e identificar o que o deixa satisfeito em relação ao serviço prestado. Os questionários usuais de satisfação, encontrados na literatura, voltados a clientes ou pacientes não são diretamente aplicáveis a doadores, uma vez que os doadores não são propriamente conceituados como indivíduos que comparecem à instituição somente para receber um produto ou atendimento, mas participam de um processo em que contribuem oferecendo gratuitamente um bem de natureza material, que é seu próprio sangue. Diante da ausência de instrumentos validados em língua portuguesa, o objetivo do presente estudo é construir um instrumento capaz de avaliar a satisfação do doador de sangue, bem como estudar a validade de construto e consistência interna. O estudo será conduzido em quatro etapas: (1) desenvolvimento do instrumento com base em grupos focais e no instrumento introduzido por Borges et al. (2005), (2) validação de conteúdo, considerando a avaliação do instrumento por um grupo de especialistas, (3) pré-teste do instrumento e (4) aplicação do instrumento para validação em uma amostra de 1.019 doadores de sangue. $\mathrm{O}$ instrumento proposto possui 25 itens que caracterizam atributos da satisfação do doador de sangue, divididos em três domínios: acesso/conveniência, aspectos técnicos e aspectos interpessoais. $\mathrm{O}$ instrumento apresentou satisfatória consistência interna, quanto ao conjunto de itens. Propõe-se o gráfico desempenho-importância (GDI) como uma ferramenta simples de interpretação dos dados obtidos pelo instrumento, na rotina de monitoramento da qualidade do serviço prestado por bancos de sangue. Considerando os dados obtidos para a amostra de 1.019 doadores, o GDI permitiu identificar os itens que, se melhorados, a satisfação geral do doador tenderá a aumentar, bem como os itens que precisam ser mantidos para a garantia da satisfação do doador. $O$ instrumento proposto poderá contribuir para a qualidade dos serviços de hemoterapia, ao capturar informações capazes de descrever os aspectos em que os doadores se sentem insatisfeitos quanto ao atendimento ou serviços prestados.

Palavras-chave: doadores de sangue, validação de instrumento, grupos focais, satisfação. 


\section{Abstract}

TROVÃO, A. C. G. B. Construction and validation of an instrument designed to blood donor's satisfaction. Thesis (Doctorate Degree) - Ribeirão Preto Medical School - USP, Ribeirão Preto, SP, Brazil, 2018.

In 2015, the blood donation rate for the country was estimated by the Ministry of Health by 18.2 donations per 1,000 inhabitants, whereas in 2014 , this rate was 18.49 . The maintenance of blood stocks in the country is a constant in hemotherapy services and the strategies of donor recruitment and loyalty are essential. Thus, it is necessary to know donor's expectations regarding the assistance during the donation and to identify what makes them feel satisfied with the service delivered. The usual satisfaction questionnaires, found in the literature, designed to customers or patients are not directly applicable to donors, once donors are not properly conceived as subjects who attend to the institution only to receive a product or care, actually they take part in a process to which they contribute by offering goods of material nature for free, in this case their own blood. Upon the absence of validated instruments in Portuguese, the aim of this study is to construct an instrument capable of assessing blood donor's satisfaction, as well as to study its validity and internal consistence. The study will be conducted in four steps: (1) development of the instrument based on focus groups and on the instrument introduced by Borges et al. (2005), (2) validation of the content, considering the instrument evaluation by a group of experts, (3) instrument pre-test, and (4) application of the instrument to validate a sample of 1,019 blood donors. The instrument proposed has 25 items characterizing the attributes of blood donor's satisfaction, divided in three domains: access/convenience, technical aspects, and interpersonal aspects. The instrument showed satisfactory internal consistence in relation to the set of items. We propose the performance-importance graph (PIG) as a simple tool for the interpretation of the data obtained by the instrument, in the routine of quality monitoring of the service delivered by blood banks. Considering the data obtained for the sample of 1,019 donors, the PIG allowed to identify the items that, if improved, donor's overall satisfaction should tend to increase, as well as the items that have to be kept in order to guarantee donor's satisfaction. The instrument proposed might contribute to the quality of hemotherapy services by capturing information capable of describing the aspects donors feel most unsatisfied with, in relation to the attention or services delivered.

Key words: blood donors, instrument validation, focus groups, satisfaction. 


\section{Sumário}

1. Introdução 9

2. Justificativa 14

3. Objetivos 15

4. Método 16

5. Resultados

6. Discussão $\quad 79$

$\begin{array}{lr}\text { 7. Conclusão } & \mathbf{8 9}\end{array}$

8. Referências Bibliográficas $\quad \mathbf{9 0}$

$\begin{array}{ll}\text { Apêndice I } & 96\end{array}$

$\begin{array}{ll}\text { Apêndice II } & 98\end{array}$

$\begin{array}{ll}\text { Apêndice III } & 107\end{array}$

$\begin{array}{lr}\text { Apêndice IV } & \mathbf{1 1 0}\end{array}$

$\begin{array}{lr}\text { Apêndice V } & 114\end{array}$

$\begin{array}{lr}\text { Anexo } & 115\end{array}$ 


\section{Introdução}

O reconhecimento legal da doação voluntária de sangue no Brasil se dá no ano de 1950 através da Lei Federal 1.075, que dá visibilidade à relevância deste ato prestado à sociedade. No entanto, apenas em 1965, com Lei Federal 4.701, que elenca as bases da Política Nacional do Sangue, o incentivo à doação voluntária de sangue apresenta-se como dever cívico-social (CARNEIRO E LOPES, 2002; GUERRA, 2005).

Entretanto, ainda hoje os hemocentros do país enfrentam dificuldades em manter seus estoques de sangue satisfatórios para atender as necessidades específicas e emergenciais, uma vez que, em 2015, apenas $1,82 \%$ da população realizou este ato solidário, enquanto que a Organização Mundial de Saúde preconiza que em torno de 3 a 5\% da população seja doadora (MINISTÉRIO DA SAÚDE, 2007; 2017). Como ainda não há substituto para o tecido sanguíneo em sua totalidade, este cenário de escassez torna-se ainda mais alarmante frente às evidências estatísticas de que as doações de sangue não acompanham o aumento da demanda, caracterizando-se um problema que afeta a saúde coletiva (RODRIGUES et al., 2011).

Diante desse cenário, os hemocentros do país necessitam de estratégias de captação de doadores de sangue eficientes no sentido de conquistar a fidelidade dos mesmos, uma vez que doadores de repetição apresentam mais segurança sorológica e consequentemente, transfusional (LUDWIG, 2005). No contexto da fidelização dos doadores há a preocupação em aumentar a conveniência para novas doações (SCHLUMPF et al., 2008), promover o treinamento e educação continuada dos profissionais (RINGWALD et al., 2010) e conhecer os motivos pelos quais levam um 
doador a se declarar como satisfeito durante seu atendimento (BORGES et al., 2005; GIACOMINI E LUNARDI FILHO, 2010).

A literatura aponta três categorias de estratégias de captação de doadores: acolhimento, campanhas e estratégias educativas (RODRIGUES E REIBNITZ, 2011). O acolhimento, caracterizado como o bom atendimento aos doadores, é apontado como possibilidade de fidelização (NGUYEN et al., 2008). Já as campanhas caracterizam-se como estratégias pontuais que acontecem em dado momento por razões específicas (KEZWER, 2000; SOBREIRA DE MOURA et al., 2006). Em geral, campanhas que contam com o apoio dos meios de comunicação repercutem de maneira satisfatória, pois contribuem no sentido de socializar informações acerca da doação e desmistificar significados (MATHEW et al., 2007; MOOG E FOURNÉ, 2007). As estratégias educativas são mais efetivas, pois promovem efeitos positivos a curto, médio e longo prazo, principalmente quando voltadas à formação de hábitos na população jovem, enfocando a doação de sangue como um ato solidário, responsável e de responsabilidade social (DOS SANTOS et al., 2009).

Algumas publicações sugerem estudos de mercado social que investiguem o que impedem as pessoas de doarem sangue e, principalmente, o que leva doadores a deixarem de doar, o que demanda estratégias de captação e fidelização de doadores (GLYNN et al., 2006; TISON et al., 2007; MARANTIDOU et al., 2007; SCHLUMPF et al., 2008; PEREIRA et al., 2016; LIVITZ et al., 2017; SUEMNIG et al., 2017).

O conhecimento das concepções do doador, de seus valores e sentimentos tornase essencial para melhor fidelizá-lo ao serviço, uma vez que conhecer suas expectativas facilita o atendimento às suas reais necessidades durante o ato de doar, contribuindo para a satisfação e, consequentemente, para o aumento da população doadora (RODRIGUES E REIBNITZ, 2011). Logo, conhecer o que deixa o doador satisfeito em 
seu atendimento torna-se importante não somente para fidelizá-lo no serviço, mas também para ser um multiplicador de estratégias de captação na sociedade ao recomendar e incentivar a doação de sangue.

A certificação de unidades de hemoterapia pela Norma NBR ISSO 9001:2000 exige o conhecimento e o monitoramento contínuo do grau de satisfação dos doadores em relação ao serviço. Logo, a satisfação do doador está ligada não somente a estratégias de captação, mas também ao sistema de gestão da qualidade da instituição (BORGES et al., 2005).

Os instrumentos existentes para mensuração da satisfação de cliente/paciente não são diretamente aplicáveis a doadores de sangue por uma questão conceitual, uma vez que o doador não se comporta como consumidor, pois está doando um produto. Desse modo, sua satisfação volta-se ao serviço prestado a não a um produto adquirido (BORGES et al., 2005).

$\mathrm{Na}$ literatura, há poucos estudos que propõem instrumentos em língua portuguesa para a mensuração da satisfação do doador de sangue. Um estudo realizado no Hemocentro do Hospital das Clínicas de Ribeirão Preto introduziu um instrumento voltado a mensurar a satisfação de doadores de sangue, sendo uma amostra de 407 doadores utilizada para a avaliação da fidedignidade da escala (BORGES et al., 2005). Os participantes classificaram 18 itens apresentados no Quadro 1, na forma de afirmativas, segundo uma escala de Likert de 4 respostas, variando em "totalmente errado" a "totalmente certo" (por exemplo, o item 1 é apresentado como a afirmativa: "É fácil chegar ao Hemocentro"). Foi encontrada alta consistência interna do questionário, porém os autores enfatizam a necessidade de validação do mesmo (BORGES et al., 2005). As afirmativas são divididas em três domínios: acessibilidade/conveniência, aspectos técnicos e aspectos interpessoais. 
Quadro 1. Itens constantes do questionário de satisfação de doadores de sangue introduzido por Borges et al. (2005).

\begin{tabular}{cll}
\hline Item & Item & Domínio \\
\hline 1 & Facilidade para chegar ao Hemocentro & Acesso/conveniência \\
2 & Tempo gasto na doação de sangue & Acesso/conveniência \\
3 & Limpeza do Hemocentro & Aspectos técnicos \\
4 & O prazer dos funcionários em atender & Aspectos interpessoais \\
5 & Confiança na qualidade do material utilizado & Aspectos técnicos \\
6 & Lanche oferecido & Aspectos técnicos \\
7 & Rapidez no atendimento durante a doação de sangue & Acesso/conveniência \\
8 & Espaço físico do Hemocentro & Aspectos técnicos \\
9 & Gentileza dos funcionários & Aspectos interpessoais \\
10 & O sentir-se à vontade durante a entrevista & Aspectos interpessoais \\
11 & Explicações dos funcionários & Aspectos interpessoais \\
12 & Capacidade profissional dos funcionários & Aspectos interpessoais \\
13 & O respeito no tratamento & Aspectos interpessoais \\
14 & Atendimento do funcionário que faz os exames & Aspectos interpessoais \\
15 & Satisfação com o funcionário da recepção & Aspectos interpessoais \\
16 & Atendimento e orientações da assistente social & Aspectos interpessoais \\
17 & Facilidade de encontrar vagas no estacionamento & Acesso/conveniência \\
18 & Atendimento do funcionário que colhe o sangue & Aspectos interpessoais \\
\hline
\end{tabular}

Araújo et al. (2011) desenvolveram um instrumento para avaliar a aceitabilidade de doadores em relação às etapas da doação de sangue (recepção, triagens de enfermagem e médica, e coleta) em um hemocentro público do Recife, ressaltando o acolhimento. Neste estudo, os autores não usaram o termo "satisfação", mas aceitabilidade, definida como a conformidade da oferta aos valores e expectativas dos usuários. Os autores enfatizaram que "o conceito de aceitabilidade é multifacetado e pressupõe a influência dos padrões culturais nas apreciações individuais, sobretudo, acerca da competência técnica, acesso a cuidado, relações interpessoais, comunicação e características do local de prestação do serviço” (ARAÚJO et al., 2011). Como resultados, foi mostrado que a sala de coleta foi o setor melhor avaliado, sendo feitas referências à impessoalidade, à persistência de dúvidas e à rapidez da entrevista médica. 
Com o objetivo de avaliar a satisfação dos doadores de sangue do Centro Regional de Sangue do Porto, Portugal, Cardoso et al. (2010) desenvolveram um instrumento que avaliou o grau de satisfação em relação ao atendimento prestado pelas diferentes classes profissionais (médico, enfermeiro, administrativo e o "assistente operacional no bar", ou seja o funcionário da lanchonete) e em relação ao que denominaram "instalações" (limpeza, conforto, privacidade e a estrutura geral).

A presente Tese de Doutorado busca dar continuidade ao estudo de BORGES et al. (2005), revisando os itens do questionário de satisfação do doador de sangue a partir de grupos focais, com o objetivo de propor um novo instrumento, uma vez que alguns itens importantes ao doador possam não ter sido contemplado naquele questionário. Em adição, o novo instrumento será então validado. 


\section{Justificativa}

A manutenção dos estoques de sangue no país é um desafio constante nos serviços de hemoterapia e estratégias de fidelização dos doadores e que aumentem a conveniência a novas doações são necessárias. Logo, conhecer as expectativas do doador em relação ao atendimento durante a doação, ou seja, o que o deixa satisfeito em relação ao serviço, torna-se essencial nesse cenário. Tendo em vista a falta de um instrumento validado em língua portuguesa, e o fato que os questionários usuais de satisfação cliente/paciente não compatíveis com a mensuração da satisfação de doadores de sangue, o presente estudo vem de encontro a estas necessidades. 


\section{Objetivos}

O objetivo do presente estudo é introduzir e validar um instrumento capaz de avaliar a satisfação dos doadores de sangue do Núcleo de Hemoterapia de Franca, SP, de acordo com as etapas apresentadas na Figura 1.

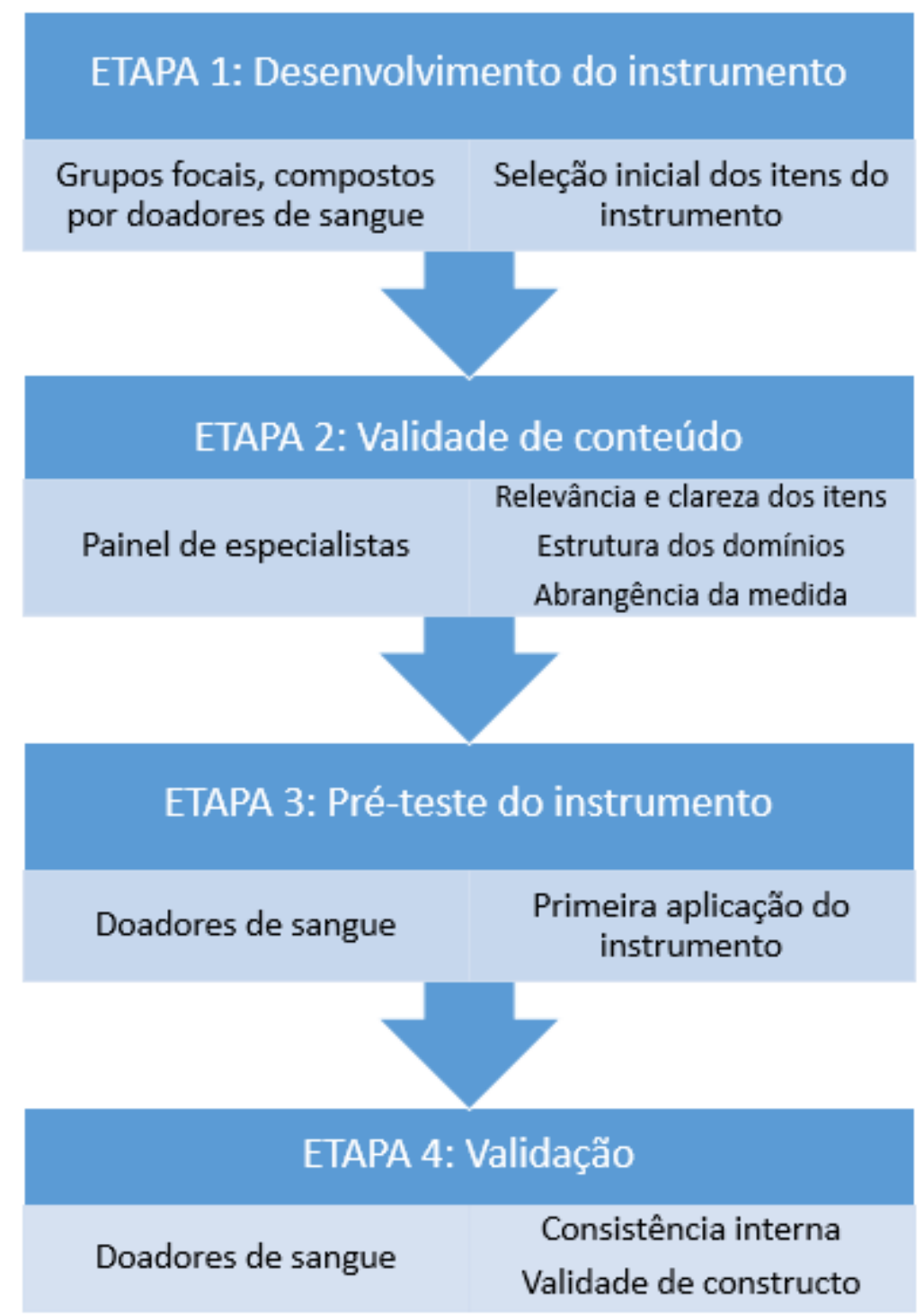

Figura 1. Etapas da pesquisa.

Como objetivo secundário, será apresentada uma proposta de interpretação dos resultados obtidos pela aplicação do instrumento. 


\section{Método}

Todas as etapas desta pesquisa foram conduzidas no Núcleo de Hemoterapia de Franca, pertencente à Fundação Hemocentro de Ribeirão Preto. Para a proposta de um instrumento de avaliação da satisfação do doador de sangue, foram consideradas as premissas:

- O instrumento deve ser autoaplicável, de modo a não necessitar que um funcionário do Hemocentro seja responsável pela coleta das informações, ou que os funcionários em serviço precisem sair de suas rotinas.

- Os itens constantes no instrumento não são destinados a gerar uma "medida" da satisfação do doador através da soma dos valores atribuídos às respostas ou outra equação que utilize as respostas aos itens. O objetivo dos itens é permitir o conhecimento de atributos da satisfação que precisem ser aperfeiçoados para o melhor atendimento do doador de sangue.

- Neste sentido, o conjunto de itens do instrumento também não permite comparações longitudinais e a verificação se a satisfação “cresceu” o não ao longo do tempo.

- Uma "medida" geral da satisfação do doador será obtida diretamente de uma questão, que convida o doador a indicar o quanto ele está satisfeito com o serviço prestado pelo Hemocentro.

- Os itens constantes do instrumento devem referir-se a atributos da qualidade que podem ser, de alguma forma, modificáveis (por exemplo, não há sentido em incluir itens sobre a localização do Hemocentro, se não há a viabilidade 
de mudá-lo de lugar, ou sobre o espaço físico, se não são viáveis reformas em suas estruturas).

\subsection{Etapa 1: Desenvolvimento do instrumento}

A Etapa 1 da pesquisa prevê o uso de grupos focais para buscar, entre doadores de sangue, novos itens que podem estar associados à doação de sangue e então, permitir uma revisão do questionário de Borges et al. (2005).

\subsubsection{População Estudo}

Indivíduos que doam sangue, por qualquer motivo, não incluindo portadores de deficiência visual, auditiva e motora. Serão excluídos os indivíduos que classificados como inaptos na triagem clínica.

\subsubsection{Critérios de inclusão}

Estão aptos a participar da Etapas 1 todos os doadores que tenham efetuado a coleta de sangue no momento da coleta de dados, exceto analfabetos e deficientes visuais, uma vez que o questionário a ser desenvolvido será autoaplicável. Deste modo, são critérios de inclusão neste estudo as regras que estabelecem a permissão para um indivíduo tornar-se doador de sangue, que, em síntese, são: ter entre 18 e 69 anos, peso superior a $50 \mathrm{~kg}$ para homens e $51 \mathrm{~kg}$ para mulheres e estar em boas condições de saúde. Embora a Portaria 158/MS de 4 de fevereiro de 2016 permita que indivíduos com idade entre 16 anos completos e 18 anos incompletos doem sangue perante 
consentimento formal de seu responsável legal, estes não serão incluídos no presente estudo, para evitar conflitos com a Resolução 466/12 do Conselho Nacional de Saúde, que expõe as diretrizes e normas regulamentadoras de pesquisas envolvendo seres humanos.

\subsubsection{Grupos Focais}

Alguns autores descrevem que a utilização de grupos focais permite enfatizar o problema na ótica de seus participantes, ou seja, evidenciar a compreensão a partir do ponto de vista dos grupos populacionais (BASCH, 1987; RAMIREZ e SHEPPERD, 1988). Segundo Basch (1987), o grupo focal leva à redução de percepções distorcidas por parte dos dirigentes, as quais são pouco efetivas na resolutividade dos problemas por não partirem da compreensão das experiências do grupo participante. Nesse sentido, o grupo focal tende a mostrar percepções de determinado assunto não capturadas anteriormente quando levadas em consideração apenas as opiniões dos dirigentes. Portanto, a essência do grupo focal está na interação entre participantes e pesquisador (IERVOLINO e PELICIONI, 2001), a partir da discussão de tópicos específicos e diretivos.

Os grupos focais costumam ser compostos por seis a 10 participantes não aparentados, são selecionados para discussão de um assunto comum a todos os participantes e com duração de uma hora e meia, costumeiramente (KRUEGER, 1988). O moderador do grupo, que pode ser o pesquisador, é responsável por proporcionar um ambiente propício para que opiniões distintas surjam e se sustentem sem pressões para que os participantes atinjam um consenso, o que descaracterizaria o grupo focal 
(CARLINI-COTRIM, 1996). O uso do grupo focal neste estudo se justifica pelo fato de que a construção do instrumento de satisfação embasada na perspectiva do doador pode trazer à tona itens no questionário que até então não foram abordados nos instrumentos de satisfação do doador utilizados no serviço.

Para a construção do questionário de satisfação do doador, foram realizados grupos focais compostos por doadores de sangue escolhidos aleatoriamente por convite através de contato telefônico. Desse modo, foram convidadas pessoas que doaram apenas uma vez, bem como doadores de repetição. Foram planejados quatro grupos com dez participantes cada um, totalizando 40 doadores, a fim de não haver perda na qualidade das informações por ausências inesperadas (MORGAN, 1988). Os grupos foram realizados semanalmente às terças-feiras, com início às 19 horas e término em torno das 20 horas, no Núcleo de Hemoterapia de Franca, em uma sala de reuniões confortável e com acomodações para todos os participantes. Após o término de cada grupo, foi oferecido um lanche leve aos participantes. Não foi oferecido, entretanto, nenhum auxílio para o transporte ou ajuda financeira para a participação na pesquisa.

Cada participante receberá as orientações acerca do funcionamento do grupo e assinará o Termo de Consentimento Livre e Esclarecido (Apêndice I). As reuniões foram gravadas e contaram com a presença de dois colaboradores: um relator para anotações de maior relevância e um observador para compreender os sentimentos, postura e gestos dos participantes com relação aos tópicos discutidos (KRUEGER, 1988). Ambos os colaboradores são familiarizados com pesquisa qualitativa. As reuniões dos grupos serão realizadas no Núcleo de Hemoterapia de Franca e terá início às $19 \mathrm{~h}$ e previsão de término para as 20 horas. 
Os dados dos grupos focais obtidos através das gravações e das anotações de observação são de natureza qualitativa e, portanto, serão transcritos e submetidos à análise de conteúdo (MORGAN, 1988). A partir das transcrições serão criadas as categorias de análise, que neste estudo, serão os itens que irão compor o questionário. Para a realização dos grupos focais foi elaborado um roteiro de perguntas, a fim de direcionar a discussão para um aprofundamento progressivo (técnica de funil), porém sem engessamento, a ponto do pesquisador precisar intervir excessivamente nas discussões, permitindo fluidez. Ao início de cada grupo, foram acordadas algumas regras como: apenas uma pessoa falar de cada vez; evitar conversas paralelas para que todos sejam ouvidos; ninguém pode dominar a discussão; e todos tem o direito de falar o que pensam sobre o assunto (GONDIM, 2003).

O grupo iniciou com a explicação que as falas seriam de forma livre e que a expressão da opinião não prejudicaria o atendimento no serviço. As perguntas debatidas sequencialmente foram: "por que motivo você doa sangue?"; "quando você vem doar, o que você espera?”; "o que deixa um doador satisfeito?"; "o que deixa um doador insatisfeito?"; "você já doou sangue em outro serviço? Como foi a experiência?”. Foi realizada cada pergunta por vez e todo conteúdo foi gravado. O conteúdo de cada grupo foi transcrito e realizada análise de conteúdo de Bardin (2011) definida como um conjunto de instrumentos de cunho metodológico que se aplicam a discursos extremamente diversificados. É um método que permite categorizar os componentes do significado da mensagem por meio de uma descrição objetiva, sistemática e quantitativa do conteúdo extraído das comunicações e sua respectiva interpretação. Portanto, a partir dos discursos dos doadores emergiram os itens de composição do questionário de 
satisfação do doador de sangue distribuídos nas três categorias propostas por Borges et al. (2005): acesso/conveniência, aspectos técnicos e aspectos interpessoais. De posse desses itens, elaborou-se o questionário, o qual foi submetido à validação por um grupo de juízes (Etapa 2).

\subsection{Etapa 2: Validade de conteúdo}

A validade de conteúdo, segundo Haynes et al. (1995), descreve o grau em que os elementos de um instrumento de avaliação são relevantes e representativos do constructo que se pretende mensurar. Estes autores descrevem que os elementos do instrumento incluem seus itens, os formatos das respostas e as instruções aos respondentes. No presente estudo, a validade de conteúdo refere-se ao julgamento da clareza e pertinência dos itens do instrumento por um painel de especialistas, no sentido de constituírem um conjunto capaz de representar a satisfação do doador à medida que seriam entendidos pelo respondente. Entendemos que esta conceituação encontra compatibilidade com aquela apresentada por Fitzner (2007) e discutida por Alexandre e Coluci (2011).

Os itens obtidos na Etapa 1 compuseram um instrumento, segundo ao menos três domínios: acessibilidade/conveniência, aspectos técnicos e aspectos interpessoais, conforme Borges et al. (2005), sendo a satisfação mensurada por uma escala de Likert. Assim, tal instrumento foi avaliado por um grupo de 12 juízes, ou seja, profissionais da área da hemoterapia com alguma experiência na construção e aplicação de questionários. Os juízes não foram informados sobre qual domínio cada item é associado. 
Critérios para a seleção de juízes são discutidos por Grant e Davis (1997) e Galdeano e Rossi (2006). O número ótimo de juízes, segundo Haynes et al. (1995), pode variar de acordo com os elementos em consideração e considerações práticas, como o tamanho do instrumento e a disponibilidade de especialistas. Outras considerações sobre o número de juízes são encontradas em Crocker et al. (1988), Grant e Davis (1997) e Lynn (1986). Como exemplo, Lynn (1986) recomenda um mínimo de cinco e um máximo de dez pessoas. Todos os juízes selecionados para esta etapa da pesquisa atuavam como profissionais na área de hemoterapia, médicos e enfermeiros, com pelo menos um ano de prática na rotina de atendimento de doador de sangue e curso superior completo. Deu-se preferência a profissionais com título de doutor ou mestre, com publicações relacionadas à temática de doadores de sangue.

A validade de conteúdo compreende quatro critérios (RUBIO et al., 2003):

(1) Relevância dos itens. Os juízes serão convidados a classificar cada item como "essencial”, "útil, mas não essencial" e "não necessário". Para cada item, será então calculado o content validity ratio (CVR), dado pela expressão:

$$
C V R=\frac{E-\frac{n}{2}}{\frac{n}{2}}
$$

em que $n$ é total de juízes e $E$ é o número total de juízes que indicaram aquele item como "essencial". O CVR varia de -1 a +1 . Quando menos da metade dos juízes classificam um item como "essencial”, o valor do CVR é negativo. A relevância de cada item em um instrumento obedecerá a critérios e pontos de corte estabelecidos por Wilson et al. (2012). 
(2) Clareza (clarity) dos itens. Quanto à sua escrita, cada item do instrumento é classificado pelos juízes segundo três possíveis respostas: “é bastante claro”, "é necessária uma pequena revisão" ou "é necessária uma substancial revisão”. Se julgarem necessário, os juízes podem escrever sugestões para se obter uma melhor escrita de cada item.

(3) Estrutura dos domínios. Os juízes foram convidados a classificar cada item do instrumento conforme seu domínio: acessibilidade/conveniência, aspectos técnicos e aspectos interpessoais. Em adição, os juízes poderiam classificar um item como pertencente a nenhum destes domínios. O índice de validade fatorial (factorial validity index, FVI), proposto por (RUBIO et al., 2003), determina o grau em que os juízes corretamente associam os itens aos seus respectivos domínios. O FVI é considerado uma medida preliminar da validade fatorial do instrumento, que será formalmente estabelecida por técnicas estatísticas de análise fatorial após a aplicação do instrumento a uma amostra de doadores de sangue. O FVI de cada item é dado pelo número de juízes que corretamente associaram o item ao seu domínio, dividido pelo número total de juízes. Uma média dos valores de FVI de cada domínio fornece um índice de validade fatorial para o instrumento.

(4) Abrangência (comprehensiveness) da medida. A abrangência da medida de satisfação é indicada pelos itens que os juízes sugerem eliminar ou adicionar ao questionário de satisfação. Dessa forma, os juízes são convidados a responder a duas perguntas, dispostas ao final do instrumento de validação de conteúdo: "Quais itens você recomenda excluir do instrumento de satisfação do doador de sangue?" e "Quais outros itens você 
sugere incluir no instrumento para se obter uma medida da satisfação do doador de sangue?"”

Foi elaborada uma ficha para os juízes anotarem suas classificações segundo a relevância dos itens, a clareza, a estrutura dos domínios e a abrangência da medida (Apêndice 2).

\subsection{Etapa 3: Pré-teste do instrumento}

Foi planejado aplicar o instrumento obtido da fase anterior a uma amostra de 100 doadores de sangue, mas, durante a aplicação, obtivemos respostas de 114 doadores. Foi incluída a cada item uma alternativa indagando ao doador se ele entendeu a pergunta, e a pesquisadora principal ficou à disposição do participante para quaisquer dúvidas. $\mathrm{O}$ instrumento foi administrado logo após a doação de sangue, na lanchonete, que fica ao lado da sala de coleta. Esta etapa não exclui a necessidade de se usar o TCLE, e foi previsto que ela poderia ocasionar em modificações no conteúdo dos itens em que os participantes relatarem dúvidas.

\subsection{Etapa 4: Validação do instrumento}

\subsubsection{Tamanho Amostral}

O tamanho amostral pretendido nesta etapa foi, a princípio, 1.000 doadores, considerando os argumentos estatísticos apresentados por Schmidt et al. (1976) sobre o 
número mínimo de indivíduos necessários para estudos de validação. Observa-se que o serviço onde foi desenvolvida a pesquisa coleta em média, 1.000 bolsas de sangue a cada mês.

\subsubsection{Variáveis}

Além das respostas ao instrumento proposto, foram obtidas informações sobre as variáveis a seguir:

- Sexo: masculino ou feminino

- Idade: em anos completos

- Quantas vezes já doou sangue: as possíveis respostas são "é a primeira vez”, "segunda vez", “3 a 5", “6 a 10" e "mais de 10 vezes".

- Escolaridade: as possíveis respostas são: "sem escolaridade", "fundamental I completo", "fundamental II completo", "ensino médio completo", "ensino superior incompleto" e "pós-graduação".

- Motivo da doação de sangue: "solicitação pelo Hemocentro", "parente, amigo ou conhecido necessitando de doação", "ajudar a manter o estoque" ou "doação autóloga".

- Pretensão de retorno a novas doações de sangue: as possíveis respostas serão: “sim”, "não" e "não sei”.

- Como chegou ao Hemocentro: "de carro próprio", "táxi/Uber”, “ônibus", “a pé”, "de carona" ou "outra forma".

- Facilidade para encontrar vaga para estacionar: "sim", "não" ou "não veio de carro".

- Tempo para chegar até o Hemocentro. 
- Uso de redes sociais. Esta variável será importante para futuros estudos sobre ferramentas de captação de doadores de sangue.

\subsubsection{Coleta de dados}

A coleta de dados foi realizada logo após a doação de sangue, na lanchonete, por meio da assinatura do Termo de Consentimento Livre e Esclarecido (TCLE), e posterior preenchimento do questionário de satisfação pelo doador. O TCLE (Apêndice III), bem o instrumento de satisfação, foram entregues pelo profissional que recepciona o doador na lanchonete, o qual explicou os objetivos da pesquisa, do sigilo das informações e deu as instruções de preenchimento após treinamento prévio pelo pesquisador. Na rotina de trabalho no serviço, este profissional já é responsável por aplicar o questionário de satisfação utilizado atualmente na instituição (durante a realização desta pesquisa, o instrumento usado de rotina foi substituído pelo instrumento em desenvolvimento). Portanto, não terá dificuldades em instruir o doador sobre o TCLE nem em instruir o doador quanto ao preenchimento, e a coleta de dados reproduz a rotina de aplicação do instrumento. Foi escolhido este momento pelo fato de ser um local tranquilo, aconchegante e onde o doador dispõe tempo e espaço físico suficiente para preenchimento do questionário, além de ser o momento final de sua estadia no serviço (ver detalhes no Apêndice IV). Neste local e momento, o doador pôde avaliar todo o processo de doação, inclusive o lanche e atendimento oferecidos na lanchonete.

O instrumento foi ser preenchido pelo próprio doador de sangue, prevendo a forma em que futuramente deverá ser usado dentro da rotina da instituição, se adotado. Após o preenchimento do questionário, o profissional da lanchonete recolheu o questionário preenchido. 


\subsubsection{Consistência interna}

Em um primeiro passo, estimou-se uma matriz de correlações policóricas (HOLGADO-TELLO et al., 2010) entre as respostas aos itens do instrumento, e entre os itens e a satisfação geral. Justifica-se o uso de correlações policóricas pela natureza das respostas aos itens, que não constitui uma variável contínua.

A partir das correlações policóricas, a consistência interna do instrumento foi medida pelo alfa de Cronbach (1951), um coeficiente que varia entre 0 e 1 , e indica se os itens do instrumento formam um conjunto consistente no sentido de mensurar um mesmo objeto. Quanto mais próximo de 1 o valor, maior consistência (BLAND E ALTMAN, 1997). Será também calculada correlação do item com o total, ou seja, a correlação entre o item específico e o indicador total, depurado de sua própria contribuição (PEREIRA, 2001). Esta correlação mede a associação do item com as outras medidas tomadas em conjunto.

\subsubsection{Validade de constructo}

Utilizando a matriz de correlações policóricas, foi utilizada uma análise fatorial exploratória (PETT et al., 2003) para testar a hipótese de que o instrumento possui dimensões compatíveis com os domínios estabelecidos. Logo, esperou-se que a análise fatorial classificasse os itens em fatores com autovalor (eigenvalue) maiores ou iguais a 1, de acordo com os domínios antes estabelecidos (a princípio, acessibilidade/conveniência, aspectos técnicos e aspectos interpessoais). 


\subsubsection{Top box analysis}

Para estudar as associações entre as variáveis que caracterizam o perfil dos doadores de sangue e a satisfação geral, utilizou-se uma top box analysis, ou seja, uma análise baseada em um modelo de regressão para dados binários considerando como variável dependente uma variável que assume 1 se o doador declarou estar totalmente satisfeito com o serviço prestado pelo Hemocentro e 0 caso contrário. Neste caso, um modelo log-binomial, ou seja, um modelo com função de ligação logarítmica, e dados baseados em uma distribuição binomial, foi utilizado (SKOVE et al., 1998).

Para ilustrar a aplicabilidade do instrumento proposto, um gráfico desempenhoimportância (GDI) foi utilizado para classificar os itens em:

- Satisfação baixa, importância alta: são os itens que oportunizam a melhora da qualidade geral a curto prazo.

- Satisfação alta, importância alta: são os fatores motivacionais, os atributos de satisfação que estimulam a satisfação geral do doador quando presentes.

- Satisfação baixa, importância baixa: são os itens que aparentemente não são úteis no momento para aumentar a satisfação do doador, mas devem ser monitorados pois podem oportunizar a melhora da qualidade geral a longo prazo.

- Satisfação alta, importância baixa: são os fatores higiênicos, que não levam à satisfação geral quando presentes, mas os doadores poderão ficar insatisfeitos quando ausentes. 
A importância é medida pela correlação policórica entre cada item e a satisfação geral, enquanto o desempenho do item para a satisfação é dada pela média das respostas (1=muito satisfeito, $2=$ insatisfeito, $3=$ regular, $4=$ satisfeito, $5=$ muito insatisfeito). A classificação dos itens como fatores motivacionais e higiênicos é baseada na teoria de Herzberg para o estudo da satisfação no trabalho (BYRNE, 2006; ALSHMEMRI et al., 2017). O GDI é um gráfico de dispersão entre as médias das respostas aos itens e a respectiva correlação policórica entre cada item e a satisfação geral. Os quadrantes usados para as quatro classificações dos itens são visualizados no gráfico, de acordo com as médias dos valores descritos nos eixos das coordenadas e abscissas.

\subsubsection{Outras considerações estatísticas}

O programa SAS será utilizado em todas as análises estatísticas e o programa $\mathrm{R}$ para a confecção de gráficos de interesse.

\subsection{Questões éticas}

Todos os participantes deste estudo tiveram garantido o sigilo de suas informações, tanto aqueles que participarem dos grupos focais como aqueles que responderam o questionário. Aos primeiros, foi enfatizado que sua participação nos grupos se daria apenas no sentido de fornecer informações para a confecção do questionário de satisfação e que o conteúdo dito nas reuniões seria de conhecimento apenas dos integrantes do grupo, do pesquisador e dos colaboradores. Além disso, foi reforçado que nada do que for dito no grupo seria levado em consideração durante seu atendimento como doador de sangue, uma vez que o pesquisador trabalha na instituição. 
Riscos e desconfortos: Considerou-se que os riscos ao participar do estudo são mínimos, uma vez que poderia haver algum constrangimento durante o preenchimento dos questionários. O Termo de Consentimento Livre e Esclarecido (TCLE) informou ao participante que ele não era obrigado a responder a nenhuma pergunta se não quisesse. $\mathrm{O}$ preenchimento dos questionários não representou qualquer risco de ordem física. $\mathrm{O}$ TCLE informou ainda que qualquer participante da pesquisa teria direito a indenização conforme as leis vigentes no país, caso ocorresse dano decorrente de participação na pesquisa.

Benefícios: Não houve nenhum benefício direto aos participantes, e não foi prevista nenhuma forma de compensação ou remuneração pela participação no estudo. Entretanto, espera-se que este estudo traga informações importantes para as futuras pesquisas em saúde, dado que ela será bastante importante para entender o que os serviços de hemoterapia podem fazer para melhorar o atendimento ao doador de sangue. 


\section{Resultados}

\subsection{Etapa 1: Grupos focais}

Compareceram sete doadores no primeiro e segundo grupos e cinco no terceiro grupo, totalizando 19 participantes nos grupos focais, todos residentes em Franca. O quarto grupo previsto para esta etapa não foi realizado. Dentre as pessoas convidadas via telefone, apenas duas manifestaram possibilidade de participação. A justificativa da grande maioria seria o fato de já terem retornado ao trabalho.

Para descrever estes 19 participantes, foram anotadas as seguintes informações: sexo (masculino ou feminino), idade (em anos completos), escolaridade, quantas vezes já doou sangue, tipo de doações já realizadas (voluntárias, para alguém específico a pedido de um conhecido, e para alguém a pedido do Hemocentro), e se já houve alguma intercorrência (passou mal) em alguma doação (sim, não e não se lembra). A Tabela 1 mostra uma descrição dos participantes dos grupos focais, de acordo com estas características. Observa-se que estes participantes são relativamente heterogêneos quanto ao sexo, idade, escolaridade e número de doações prévias. O participante número 12 relatou já ter feito todos os tipos de doações, dentro as classificações desta variável. 
Tabela 1. Participantes dos grupos focais, Etapa 1 da pesquisa.

\begin{tabular}{|c|c|c|c|c|c|c|}
\hline 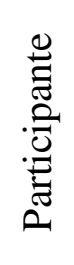 & 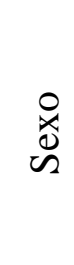 & $\frac{\mathscr{Z}}{\tilde{\sigma}}$ & 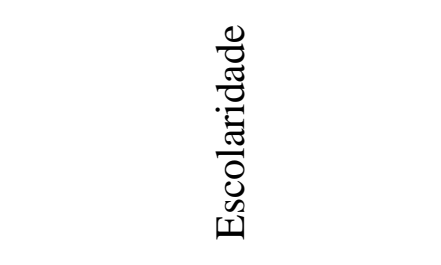 & 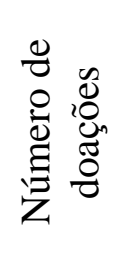 & 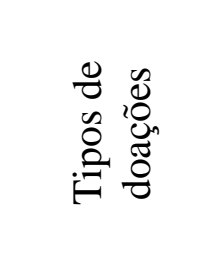 & 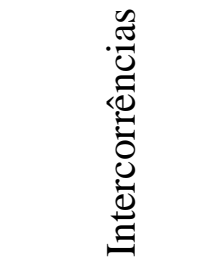 \\
\hline 1 & $\mathrm{~F}$ & 51 & Médio completo & 6 & Voluntária & Não \\
\hline 2 & $\mathrm{~F}$ & NI & Sem escolaridade & 6 & Voluntária & Não \\
\hline 3 & $\mathrm{~F}$ & 27 & Superior completo & 5 & Voluntária & Não \\
\hline 4 & $\mathrm{M}$ & 38 & Fundamental incompleto & 5 & Voluntária & Não \\
\hline 5 & $\mathrm{M}$ & 44 & Superior completo & 4 & A pedido & Não \\
\hline 6 & M & 48 & Fundamental incompleto & 6 & Voluntária & Não \\
\hline 7 & $\mathrm{~F}$ & 22 & Superior completo & 6 & Voluntária & Não \\
\hline 8 & $\mathrm{M}$ & 30 & Superior completo & 1 & Voluntária & Não \\
\hline 9 & $\mathrm{~F}$ & 28 & Superior completo & 6 & Voluntária & Não \\
\hline 10 & $\mathrm{M}$ & 49 & Fundamental completo & 6 & Voluntária & Não \\
\hline 11 & $\mathrm{~F}$ & 57 & Médio incompleto & 6 & Voluntária & Não \\
\hline 12 & $\mathrm{M}$ & 29 & Médio completo & 6 & Diversos & Sim \\
\hline 13 & $\mathrm{M}$ & 19 & Médio completo & 4 & Voluntária & Não \\
\hline 14 & $\mathrm{~F}$ & 43 & Médio completo & 6 & Voluntária & Não \\
\hline 15 & M & 55 & Fundamental incompleto & 6 & Voluntária & Não lembra \\
\hline 16 & M & 31 & Superior completo & 6 & Voluntária & Não \\
\hline 17 & $\mathrm{M}$ & 63 & Médio incompleto & 6 & Voluntária & Não \\
\hline 18 & $\mathrm{M}$ & 35 & Fundamental completo & 6 & Voluntária & Não \\
\hline 19 & M & NI & Médio completo & 6 & Voluntária & Não \\
\hline
\end{tabular}

M: Masculino, F: Feminino, NI: não informou.

Cada participante recebeu as orientações acerca do funcionamento do grupo e assinou o Termo de Consentimento Livre e Esclarecido (Apêndice III). As reuniões foram gravadas e contaram com a presença de dois colaboradores: um relator para anotações de maior relevância e um observador para compreender os sentimentos, postura e gestos dos participantes com relação aos tópicos discutidos (KRUEGER, 1988). Ambos os colaboradores eram familiarizados com pesquisa qualitativa. 
Destas anotações, a Tabela 2 ilustra a percepção mais marcante do discurso de cada participante.

Tabela 2. Percepção sobre o que é mais importante para a satisfação do doador, segundo os participantes dos grupos focais

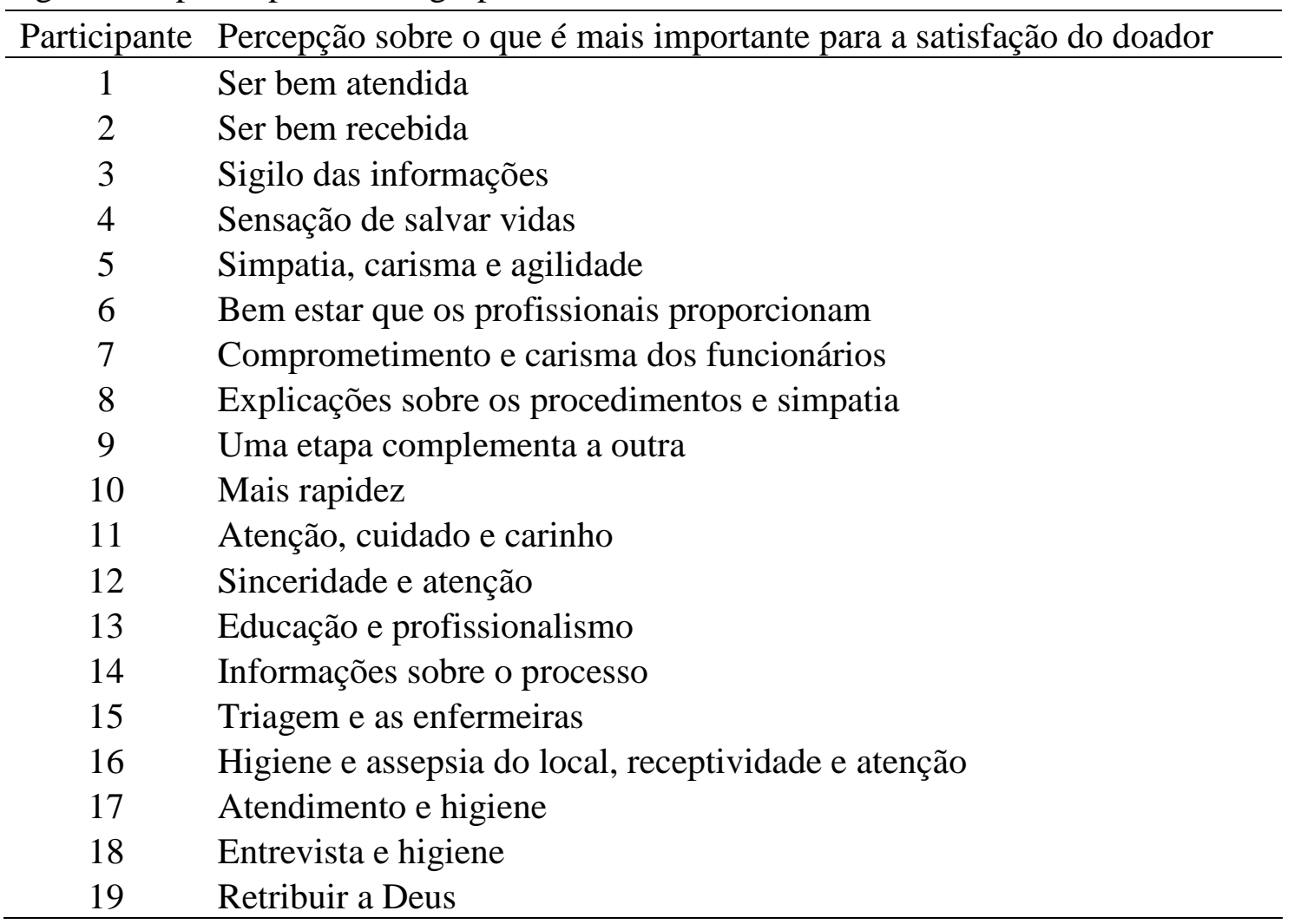

De forma geral, observou-se uma valorização pelos aspectos interpessoais, como o atendimento dos profissionais (participantes 1, 2, 5, 6, 7, 8, 11, 12, 13, 14 e 15), e técnicos $(3,9,10,17,18)$.

Elaborou-se então um novo instrumento, com 25 itens, como mostrado nas Figuras 2 e 3 . A escala de quatro respostas, variando em "totalmente errado" a "totalmente certo", apresentada no instrumento de Borges et al. (2005) foi substituída por outra, de cinco respostas, variando de "muito insatisfeito" a "muito satisfeito", o que seria mais diretamente orientado a uma mensuração de satisfação. Os itens não são agora mostrados como afirmativas, mas como atributos da satisfação, em que os participantes são convidados a avaliá-los de acordo com o grau de satisfação. 


\section{Questionário de Satisfação do Doador de Sangue}

Prezado(a) Doador(a),

Com o objetivo de oferecer um serviço de qualidade ao doador de sangue, pedimos sua colaboração em preencher esta pesquisa de satisfação. Sua participação é voluntária e confidencial. Você não deve escrever seu nome nesta folha, de forma que você não será identificado em nenhum momento.

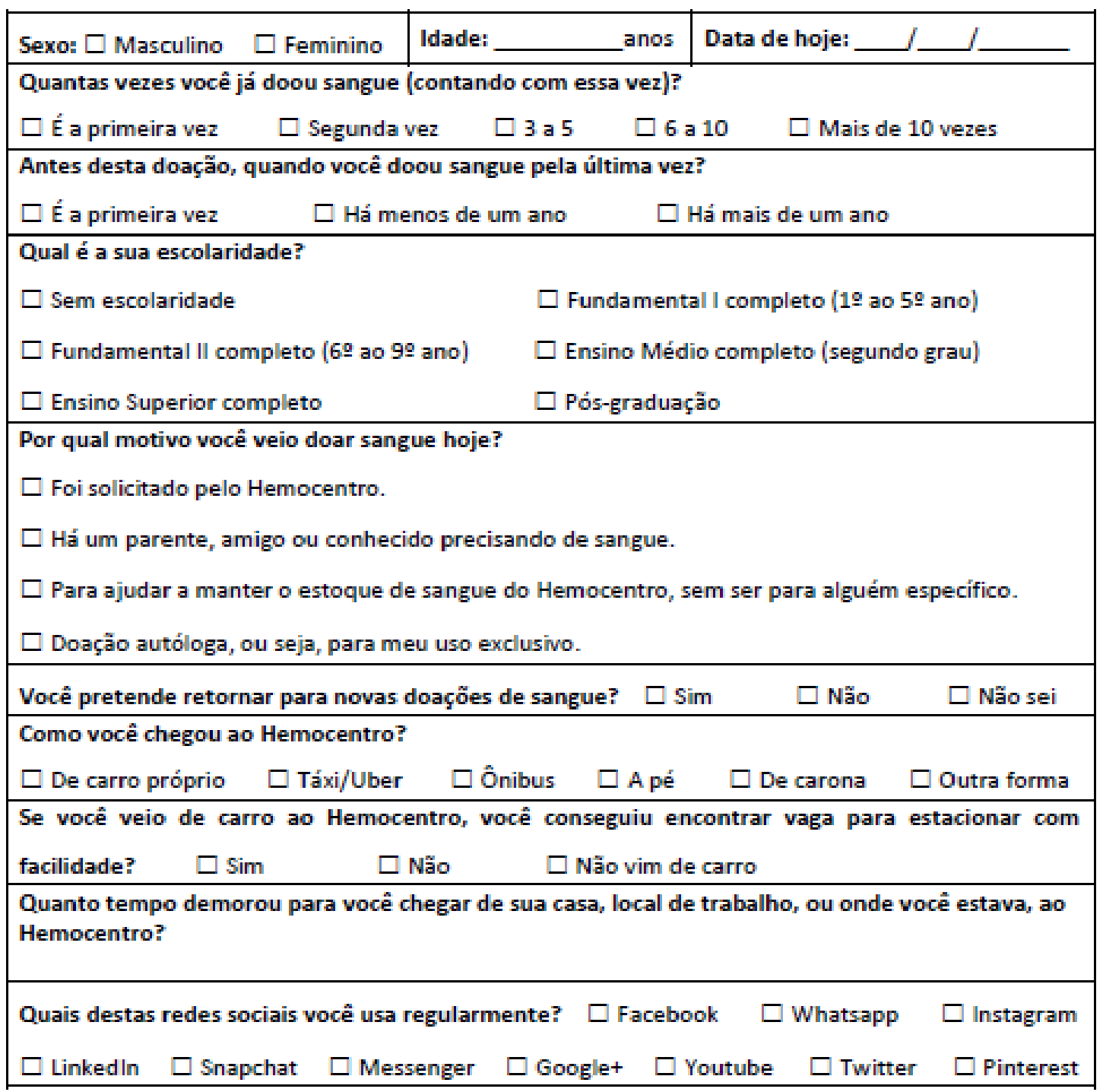

De uma maneira geral, o quanto você ficou satisfeito(a) com o serviço prestado pelo Hemocentro?

\begin{tabular}{|c|c|c|c|c|}
\hline $\begin{array}{c}\text { Muito } \\
\text { insatisfeito(a) }\end{array}$ & Insatisfeito(a) & Regular & Satisfeito(a) & Muito \\
$\square$ & $\square$ & $\square$ & $\square$ & $\square$ \\
\hline
\end{tabular}

No verso desta folha, há alguns itens que podem estar relacionados à sua satisfação ou insatisfação quanto ao serviço que você recebeu HOJE no Hemocentro. Por favor, em cada item, marque com um " $\mathrm{X}$ " a resposta mais adequada à sua percepção de satisfação.

Figura 2. Questionário de satisfação do doador (frente), versão entregue aos juízes para a etapa de validação de conteúdo. 


\begin{tabular}{|c|c|c|c|c|c|}
\hline & $\begin{array}{l}\text { Muito } \\
\text { insatisfeito }\end{array}$ & Insatisfeito & Regular & Satisfeito & $\begin{array}{l}\text { Muito } \\
\text { satisfeito }\end{array}$ \\
\hline A facilidade para se chegar ao Hemocentro & $\square$ & $\square$ & $\square$ & $\square$ & $\square$ \\
\hline O atendimento do pessoal da recepção & $\square$ & $\square$ & $\square$ & $\square$ & $\square$ \\
\hline $\begin{array}{l}\text { A gentileza do profissional que fez a } \\
\text { entrevista antes da doação }\end{array}$ & $\square$ & $\square$ & $\square$ & $\square$ & $\square$ \\
\hline $\begin{array}{l}\text { O tempo gasto durante a entrevista, antes } \\
\text { da doação de sangue }\end{array}$ & $\square$ & $\square$ & $\square$ & $\square$ & $\square$ \\
\hline $\begin{array}{l}\text { O atendimento do profissional que mediu a } \\
\text { minha pressão antes da entrevista }\end{array}$ & $\square$ & $\square$ & $\square$ & $\square$ & $\square$ \\
\hline $\begin{array}{l}\text { O conforto da sala onde fiquei esperando } \\
\text { ser chamado(a) para doar sangue }\end{array}$ & $\square$ & $\square$ & $\square$ & $\square$ & $\square$ \\
\hline $\begin{array}{l}\text { A limpeza das salas que eu estive antes de } \\
\text { ser chamado para coletar sangue }\end{array}$ & $\square$ & $\square$ & $\square$ & $\square$ & $\square$ \\
\hline $\begin{array}{l}\text { O tempo que eu tive que esperar para ser } \\
\text { chamado(a) para entrar na sala de coleta }\end{array}$ & $\square$ & $\square$ & $\square$ & $\square$ & $\square$ \\
\hline $\begin{array}{l}\text { A gentileza do profissional que coletou o } \\
\text { meu sangue }\end{array}$ & $\square$ & $\square$ & $\square$ & $\square$ & $\square$ \\
\hline $\begin{array}{l}\text { A segurança que o Hemocentro me passa } \\
\text { quanto ao material usado para a coleta }\end{array}$ & $\square$ & $\square$ & $\square$ & $\square$ & $\square$ \\
\hline $\begin{array}{l}\text { O cuidado que eu sinto estar recebendo, } \\
\text { durante a doação de sangue }\end{array}$ & $\square$ & $\square$ & $\square$ & $\square$ & $\square$ \\
\hline A higiene da sala de coleta & $\square$ & $\square$ & $\square$ & $\square$ & $\square$ \\
\hline $\begin{array}{l}\text { A atenção que o profissional que coleta } \circ \\
\text { sangue tem naquilo que está fazendo }\end{array}$ & $\square$ & $\square$ & $\square$ & $\square$ & $\square$ \\
\hline O conforto da sala de coleta & $\square$ & $\square$ & $\square$ & $\square$ & $\square$ \\
\hline $\begin{array}{l}\text { O tempo gasto durante a doação de sangue, } \\
\text { quando já estava na sala de coleta }\end{array}$ & $\square$ & $\square$ & $\square$ & $\square$ & $\square$ \\
\hline A limpeza da copa (onde servem o lanche) & $\square$ & $\square$ & $\square$ & $\square$ & $\square$ \\
\hline $\begin{array}{l}\text { As explicações que os profissionais me dão } \\
\text { em relação a tudo que eu quero entender }\end{array}$ & $\square$ & $\square$ & $\square$ & $\square$ & $\square$ \\
\hline $\begin{array}{l}\text { O lanche que me ofereceram depois da } \\
\text { doação }\end{array}$ & $\square$ & $\square$ & $\square$ & $\square$ & $\square$ \\
\hline $\begin{array}{l}\text { A quantidade de profissionais disponiveis } \\
\text { para me atender }\end{array}$ & $\square$ & $\square$ & $\square$ & $\square$ & $\square$ \\
\hline $\begin{array}{l}\text { A competência profissional das pessoas que } \\
\text { trabalham no Hemocentro }\end{array}$ & $\square$ & $\square$ & $\square$ & $\square$ & $\square$ \\
\hline $\begin{array}{l}\text { O atendimento do funcionário que trabalha } \\
\text { na copa }\end{array}$ & $\square$ & $\square$ & $\square$ & $\square$ & $\square$ \\
\hline $\begin{array}{l}\text { A disponibilidade dos profissionais em me } \\
\text { ouvir, em qualquer momento }\end{array}$ & $\square$ & $\square$ & $\square$ & $\square$ & $\square$ \\
\hline $\begin{array}{l}\text { Os horários de atendimento do } \\
\text { Hemocentro ao doador de sangue }\end{array}$ & $\square$ & $\square$ & $\square$ & $\square$ & $\square$ \\
\hline $\begin{array}{l}\text { O esforço dos profissionais para eu me } \\
\text { sentir à vontade }\end{array}$ & $\square$ & $\square$ & $\square$ & $\square$ & $\square$ \\
\hline $\begin{array}{l}\text { O respeito com que as pessoas me tratam } \\
\text { no Hemocentro }\end{array}$ & $\square$ & $\square$ & $\square$ & $\square$ & $\square$ \\
\hline
\end{tabular}

Agradecemos a sua participação!

Figura 3. Questionário de satisfação do doador (verso), versão entregue aos juízes para a etapa de validação de conteúdo. 
$\mathrm{Na}$ definição dos itens do novo instrumento, os resultados dos grupos focais pareceram confirmar a importância dos atributos de satisfação do instrumento de Borges et al. (2005), mas agora alguns itens buscaram ser mais específicos em relação às diferentes etapas e espaços físicos do processo de doação de sangue.

Objetivando buscar correlações entre as respostas a cada item e uma "satisfação geral", foi acrescentado uma pergunta: "De uma maneira geral, o quanto você ficou satisfeito(a) com o serviço prestado pelo Hemocentro?" (Figura 2). Esta pergunta foi colocada antes dos itens/atributos específicos da satisfação (Figura 3), de modo que os respondentes informassem sua "satisfação geral” sem um possível viés de um estímulo causado pelos textos destes itens. Foram acrescidas também perguntas (Figura 2) sobre o sexo, idade, número de doações, escolaridade, motivo da doação, intenção de doar novamente, como chegou ao Hemocentro, tempo de deslocamento ao Hemocentro e uso de redes sociais. Esta última pergunta foi formulada com o objetivo de fornecer informações para estratégias de captação de doadores de sangue, sem uma associação estrita com a satisfação do doador de sangue.

\subsection{Etapa 2: Validade de conteúdo}

Participaram da etapa de validade de conteúdo 12 juízes, com idade entre 30 a 60 anos e tempo de serviço em hemoterapia de 5 a 26 anos, conforme descritos na Tabela 3. Foram convidados alguns profissionais com experiência em hematologia, que trabalham em outros centros (Curitiba, Batatais e Campo Grande), e estavam no Núcleo de Hemoterapia de Franca para algum treinamento ou visita técnica. 
Tabela 3. Caracterização dos juízes que participaram da etapa de validação de conteúdo.

\begin{tabular}{cccccc}
\hline & $\begin{array}{c}\text { Idade } \\
\text { (anos) }\end{array}$ & $\begin{array}{c}\text { Tempo de } \\
\text { serviço } \\
\text { (anos) }\end{array}$ & $\begin{array}{c}\text { Cidade em que } \\
\text { trabalha }\end{array}$ & Curso de Graduação & $\begin{array}{c}\text { Maior } \\
\text { titulação }\end{array}$ \\
\hline Juiz 1 & 30 & 5 & Ribeirão Preto & Ciências Biológicas & Mestrado \\
Juiz 2 & 51 & 17 & Curitiba & Enfermagem & Mestrado \\
Juiz 3 & 40 & 5 & Curitiba & Enfermagem & Mestrado \\
Juiz 4 & 46 & 21 & Batatais & Biomedicina & Graduação \\
Juiz 5 & 56 & 22 & Batatais & Farmacêutica & Graduação \\
Juiz 6 & 33 & 9 & Campo Grande & Enfermeiro & Doutorado \\
Juiz 7 & 56 & 26 & Franca & Medicina & Especialização \\
Juiz 8 & 43 & 20 & Franca & Farmácia Bioquímica & Mestrado \\
Juiz 9 & 60 & 20 & Franca & Enfermagem & Graduação \\
Juiz 10 & 39 & 7 & Franca & Enfermagem & Graduação \\
Juiz 11 & 49 & 21 & Franca & Enfermagem & Graduação \\
Juiz 12 & 55 & 25 & Franca & Medicina & Doutorado \\
\hline
\end{tabular}

\section{Relevância dos itens}

A Tabela 4 mostra o content validity ratio (CVR) para cada item, dado pela expressão

$$
C V R=\frac{E-\frac{n}{2}}{\frac{n}{2}},
$$

em que $n=12$ é total de juízes e $E$ é o número total de juízes que indicaram aquele item como "essencial”. O valor crítico para este número de juízes é 0,566 (de acordo com os pontos de corte propostos por Wilson et al., 2012), de forma que itens com CVR menores que este valor têm a relevância questionada pelos juízes. Os itens 4, 6, 15, 18, 19, 21, 22 e 24 resultaram em valores de CVR menores que 0,566. 
Tabela 4. Content validity ratio (CVR) para os itens do instrumento.

\begin{tabular}{|c|c|c|c|c|}
\hline & Essencial & $\begin{array}{l}\text { Útil, mas } \\
\text { não } \\
\text { essencial }\end{array}$ & $\begin{array}{l}\text { Desneces- } \\
\text { sário }\end{array}$ & CVR \\
\hline $\begin{array}{l}\text { 1. A facilidade para se chegar ao } \\
\text { Hemocentro }\end{array}$ & $6(50 \%)$ & $6(50 \%)$ & 0 & 0,00 \\
\hline 2. O atendimento do pessoal da recepção & $12(100 \%)$ & 0 & 0 & 1,00 \\
\hline $\begin{array}{l}\text { 3. A gentileza do profissional que fez a } \\
\text { entrevista antes da doação }\end{array}$ & $11(92 \%)$ & $1(8 \%)$ & 0 & 0,83 \\
\hline $\begin{array}{l}\text { 4. O tempo gasto durante a entrevista, } \\
\text { antes da doação de sangue }\end{array}$ & $9(75 \%)$ & $3(25 \%)$ & 0 & 0,50 \\
\hline $\begin{array}{l}\text { 5. O atendimento do profissional que } \\
\text { mediu a minha pressão antes da } \\
\text { entrevista }\end{array}$ & 11 (92\%) & $1(8 \%)$ & 0 & 0,83 \\
\hline $\begin{array}{l}\text { 6. O conforto da sala onde fiquei } \\
\text { esperando ser chamado(a) para doar } \\
\text { sangue }\end{array}$ & $9(75 \%)$ & $3(25 \%)$ & 0 & 0,50 \\
\hline $\begin{array}{l}\text { 7. A limpeza das salas que eu estive antes } \\
\text { de ser chamado para coletar sangue }\end{array}$ & $12(100 \%)$ & 0 & 0 & 1,00 \\
\hline $\begin{array}{l}\text { 8. O tempo que eu tive que esperar para } \\
\text { ser chamado(a) para entrar na sala de } \\
\text { coleta }\end{array}$ & $10(83 \%)$ & $2(17 \%)$ & 0 & 0,67 \\
\hline $\begin{array}{l}\text { 9. A gentileza do profissional que coletou } \\
\text { o meu sangue }\end{array}$ & $12(100 \%)$ & 0 & 0 & 1,00 \\
\hline $\begin{array}{l}\text { 10. A segurança que o Hemocentro me } \\
\text { passa quanto ao material usado para a } \\
\text { coleta }\end{array}$ & $12(100 \%)$ & 0 & 0 & 1,00 \\
\hline $\begin{array}{l}\text { 11. O cuidado que eu sinto estar } \\
\text { recebendo, durante a doação de sangue }\end{array}$ & $10(83 \%)$ & $2(17 \%)$ & 0 & 0,67 \\
\hline 12. A higiene da sala de coleta & $12(100 \%)$ & 0 & 0 & 1,00 \\
\hline $\begin{array}{l}\text { 13. A atenção que o profissional que } \\
\text { coleta o sangue tem naquilo que está } \\
\text { fazendo }\end{array}$ & $12(100 \%)$ & 0 & 0 & 1,00 \\
\hline 14. O conforto da sala de coleta & $11(92 \%)$ & $1(8 \%)$ & 0 & 0,83 \\
\hline $\begin{array}{l}\text { 15. O tempo gasto durante a doação de } \\
\text { sangue, quando já estava na sala de } \\
\text { coleta }\end{array}$ & $8(67 \%)$ & $4(33 \%)$ & 0 & 0.33 \\
\hline $\begin{array}{l}\text { 16. A limpeza da copa (onde servem o } \\
\text { lanche) }\end{array}$ & 12 (100\%) & 0 & 0 & 1,00 \\
\hline
\end{tabular}


Tabela 4. Content validity ratio (CVR) para os itens do instrumento (continuação).

\begin{tabular}{|lcccc|} 
& Essencial & $\begin{array}{c}\text { Útil, mas } \\
\text { não } \\
\text { essencial }\end{array}$ & $\begin{array}{c}\text { Desneces- } \\
\text { sário }\end{array}$ & CVR \\
\hline $\begin{array}{l}\text { 17. As explicações que os profissionais me } \\
\text { dão em relação a tudo que eu quero } \\
\text { entender }\end{array}$ & $12(100 \%)$ & 0 & 0 & 1,00 \\
\hline $\begin{array}{l}\text { 18. O lanche que me ofereceram depois } \\
\text { da doação }\end{array}$ & $7(58 \%)$ & $5(42 \%)$ & 0 & 0,17 \\
\hline $\begin{array}{l}\text { 19. A quantidade de profissionais } \\
\text { disponíveis para me atender }\end{array}$ & $9(75 \%)$ & $2(17 \%)$ & $1(8 \%)$ & 0,50 \\
\hline $\begin{array}{l}\text { 20. A competência profissional das } \\
\text { pessoas que trabalham no Hemocentro }\end{array}$ & $10(83 \%)$ & 0 & $2(17 \%)$ & 0,67 \\
\hline $\begin{array}{l}\text { 21. O atendimento do funcionário que } \\
\text { trabalha na copa }\end{array}$ & $7(58 \%)$ & $5(42 \%)$ & 0 & 0,17 \\
\hline $\begin{array}{l}\text { 22. A disponibilidade dos profissionais em } \\
\text { me ouvir, em qualquer momento }\end{array}$ & $8(67 \%)$ & $3(25 \%)$ & $1(8 \%)$ & 0,33 \\
\hline $\begin{array}{l}\text { 23. Os horários de atendimento do } \\
\text { Hemocentro ao doador de sangue }\end{array}$ & $11(92 \%)$ & $1(8 \%)$ & 0 & 0,83 \\
\hline $\begin{array}{l}\text { 24. O esforço dos profissionais para eu } \\
\text { me sentir à vontade }\end{array}$ & $9(75 \%)$ & $2(17 \%)$ & $1(8 \%)$ & 0,50 \\
\hline $\begin{array}{l}\text { 25. O respeito com que as pessoas me } \\
\text { tratam no Hemocentro }\end{array}$ & $12(100 \%)$ & 0 & 0 & 1,00 \\
\hline
\end{tabular}

\section{Clareza (clarity) dos itens}

A Tabela 5 mostra como cada item do instrumento foi classificado pelos juízes, quanto à sua escrita, segundo três possíveis respostas: "é bastante claro", "é necessária uma pequena revisão" ou "é necessária uma substancial revisão". 
Tabela 5. Clareza dos itens do instrumento.

\begin{tabular}{|c|c|c|c|}
\hline & $\begin{array}{c}\text { O item é } \\
\text { bastante } \\
\text { claro }\end{array}$ & $\begin{array}{c}\text { É preciso } \\
\text { uma } \\
\text { pequena } \\
\text { revisão }\end{array}$ & $\begin{array}{l}\text { É preciso } \\
\text { uma } \\
\text { substancial } \\
\text { revisão }\end{array}$ \\
\hline 1. A facilidade para se chegar ao Hemocentro & 10 & 2 & 0 \\
\hline 2. O atendimento do pessoal da recepção & 10 & 2 & 0 \\
\hline $\begin{array}{l}\text { 3. A gentileza do profissional que fez a } \\
\text { entrevista antes da doação }\end{array}$ & 11 & 1 & 0 \\
\hline $\begin{array}{l}\text { 4. O tempo gasto durante a entrevista, antes da } \\
\text { doação de sangue }\end{array}$ & 10 & 2 & 0 \\
\hline $\begin{array}{l}\text { 5. } O \text { atendimento do profissional que mediu a } \\
\text { minha pressão antes da entrevista }\end{array}$ & 9 & 3 & 0 \\
\hline $\begin{array}{l}\text { 6. O conforto da sala onde fiquei esperando ser } \\
\text { chamado(a) para doar sangue }\end{array}$ & 11 & 1 & 0 \\
\hline $\begin{array}{l}\text { 7. A limpeza das salas que eu estive antes de ser } \\
\text { chamado para coletar sangue }\end{array}$ & 11 & 0 & 0 \\
\hline $\begin{array}{l}\text { 8. O tempo que eu tive que esperar para ser } \\
\text { chamado(a) para entrar na sala de coleta }\end{array}$ & 11 & 1 & 0 \\
\hline $\begin{array}{l}\text { 9. A gentileza do profissional que coletou o meu } \\
\text { sangue }\end{array}$ & 11 & 1 & 0 \\
\hline $\begin{array}{l}\text { 10. A segurança que o Hemocentro me passa } \\
\text { quanto ao material usado para a coleta }\end{array}$ & 11 & 1 & 0 \\
\hline $\begin{array}{l}\text { 11. O cuidado que eu sinto estar recebendo, } \\
\text { durante a doação de sangue }\end{array}$ & 11 & 1 & 0 \\
\hline 12. A higiene da sala de coleta & 12 & 0 & 0 \\
\hline $\begin{array}{l}\text { 13. A atenção que o profissional que coleta o } \\
\text { sangue tem naquilo que está fazendo }\end{array}$ & 11 & 1 & 0 \\
\hline 14. O conforto da sala de coleta & 12 & 0 & 0 \\
\hline $\begin{array}{l}\text { 15. O tempo gasto durante a doação de sangue, } \\
\text { quando já estava na sala de coleta }\end{array}$ & 11 & 1 & 0 \\
\hline 16. A limpeza da copa (onde servem o lanche) & 12 & 0 & 0 \\
\hline $\begin{array}{l}\text { 17. As explicações que os profissionais me dão } \\
\text { em relação a tudo que eu quero entender }\end{array}$ & 11 & 1 & 0 \\
\hline $\begin{array}{l}\text { 18. O lanche que me ofereceram depois da } \\
\text { doação }\end{array}$ & 10 & 1 & 0 \\
\hline $\begin{array}{l}\text { 19. A quantidade de profissionais disponíveis } \\
\text { para me atender }\end{array}$ & 10 & 0 & 1 \\
\hline $\begin{array}{l}\text { 20. A competência profissional das pessoas que } \\
\text { trabalham no Hemocentro }\end{array}$ & 11 & 1 & 0 \\
\hline
\end{tabular}


Tabela 5. Clareza dos itens do instrumento (continuação).

\begin{tabular}{|lccc|}
\hline & $\begin{array}{c}\text { O item é } \\
\text { bastante } \\
\text { claro }\end{array}$ & $\begin{array}{c}\text { É preciso } \\
\text { uma } \\
\text { pequena } \\
\text { revisão }\end{array}$ & $\begin{array}{c}\text { É preciso } \\
\text { uma } \\
\text { substancial } \\
\text { revisão }\end{array}$ \\
\hline $\begin{array}{l}\text { 21. O atendimento do funcionário que trabalha } \\
\text { na copa }\end{array}$ & 11 & 0 & 0 \\
\hline $\begin{array}{l}\text { 22. A disponibilidade dos profissionais em me } \\
\text { ouvir, em qualquer momento }\end{array}$ & 12 & 0 & 0 \\
\hline $\begin{array}{l}\text { 23. Os horários de atendimento do Hemocentro } \\
\text { ao doador de sangue }\end{array}$ & 11 & 0 & 0 \\
\hline $\begin{array}{l}\text { 24. O esforço dos profissionais para eu me sentir } \\
\text { à vontade }\end{array}$ & 11 & 0 & 0 \\
\hline $\begin{array}{l}\text { 25. O respeito com que as pessoas me tratam no } \\
\text { Hemocentro }\end{array}$ & 12 & 0 & 0 \\
\hline
\end{tabular}

A Tabela 6 exibe as sugestões apresentadas pelos juízes para a melhoria do instrumento, sendo que na última coluna são apresentados os comentários sobre estas sugestões e as ações tomadas em relação a estas.

Tabela 6. Sugestões apresentadas pelos juízes para a melhoria do instrumento e as respectivas ações e comentários dos autores.

\begin{tabular}{|lcc|}
\hline \multicolumn{1}{c}{ Sugestões } & Comentários/Ações \\
\hline & $\begin{array}{c}\text { A facilidade para encontrar e } \\
\text { chegar ao Hemocentro (Juiz 2) }\end{array}$ & $\begin{array}{c}\text { Não é recomendado que um } \\
\text { único item contemple duas } \\
\text { coisas diferentes. }\end{array}$ \\
\cline { 2 - 3 } $\begin{array}{l}\text { 1. A facilidade para se } \\
\text { chegar ao Hemocentro }\end{array}$ & $\begin{array}{c}\text { Não são todos os doadores } \\
\text { que usam o estacionamento, o } \\
\text { que pode tornar inviável um } \\
\text { Facilidade de vagas para } \\
\text { estacionamento (Juiz 12) }\end{array}$ & $\begin{array}{c}\text { na respeito. Propõe-se que } \\
\text { nameira página do } \\
\text { instrumento, exista um item } \\
\text { sobre como o doador chegou } \\
\end{array}$ \\
& no Hemocentro. \\
\hline
\end{tabular}


Tabela 6. Sugestões apresentadas pelos juízes para a melhoria do instrumento e as respectivas ações e comentários dos autores. (continuação).

\begin{tabular}{|c|c|c|}
\hline & Sugestões & Comentários/Ações \\
\hline $\begin{array}{l}\text { 2. O atendimento do } \\
\text { pessoal da recepção }\end{array}$ & $\begin{array}{l}\text { A gentileza e atenção do } \\
\text { profissional que atende na } \\
\text { recepção; a capacidade do } \\
\text { profissional que atende na } \\
\text { recepção de fornecer } \\
\text { informações (Juiz 1) }\end{array}$ & $\begin{array}{l}\text { O item objetiva avaliar a } \\
\text { satisfação quanto o } \\
\text { atendimento do pessoal da } \\
\text { recepção de uma forma geral, } \\
\text { sem especificar atributos como } \\
\text { gentileza e atenção. }\end{array}$ \\
\hline $\begin{array}{l}\text { 3. A gentileza do } \\
\text { profissional que fez a } \\
\text { entrevista antes da doação }\end{array}$ & $\begin{array}{l}\text { A clareza do profissional que } \\
\text { fez a entrevista antes da } \\
\text { doação (Juiz 12) }\end{array}$ & $\begin{array}{l}\text { O objetivo do item é a } \\
\text { gentileza. A "clareza" pode não } \\
\text { ser bem definida pelo doador. }\end{array}$ \\
\hline 4. O tempo gasto durante & $\begin{array}{l}\text { Não seria o tempo gasto até a } \\
\text { realização da entrevista, antes } \\
\text { da doação? (Juiz 6) }\end{array}$ & $\begin{array}{c}\text { O item foi modificado, } \\
\text { objetivando avaliar a satisfação } \\
\text { quanto ao tempo gasto até a } \\
\text { entrevista. }\end{array}$ \\
\hline doação de sangue & $\begin{array}{c}\text { A orientação para doadores de } \\
\text { primeira vez e de repetição } \\
\text { deveria ser diferenciada. (Juiz } \\
\text { 11) }\end{array}$ & $\begin{array}{l}\text { Não será viável desenvolver } \\
\text { um instrumento que inclui } \\
\text { itens específicos para doadores } \\
\text { de primeira vez. }\end{array}$ \\
\hline \multirow{3}{*}{$\begin{array}{l}\text { 5. O atendimento do } \\
\text { profissional que mediu a } \\
\text { minha pressão antes da } \\
\text { entrevista }\end{array}$} & $\begin{array}{l}\text { O serviço prestado pelo } \\
\text { profissional que mediu minha } \\
\text { pressão antes da entrevista } \\
\text { (Juiz 1) }\end{array}$ & $\begin{array}{l}\text { A expressão "serviço prestado" } \\
\text { é correta, mas pode não } \\
\text { representar a generalidade do } \\
\text { atendimento do profissional. }\end{array}$ \\
\hline & $\begin{array}{c}\text { Seria só a pressão arterial? Não } \\
\text { seria melhor colocar pré } \\
\text { triagem clínica? (Juiz 6) }\end{array}$ & $\begin{array}{l}\text { Não é só a pressão arterial, } \\
\text { mas a tomada da pressão } \\
\text { aparece no texto deste item } \\
\text { apenas para trazer uma } \\
\text { "referência" ao doador do } \\
\text { profissional cujo atendimento } \\
\text { se pretende avaliar a } \\
\text { satisfação. O item foi } \\
\text { modificado, indicando o } \\
\text { momento da pré-tragem } \\
\text { clínica }\end{array}$ \\
\hline & $\begin{array}{c}\text {...minha pressão, minha } \\
\text { temperatura e realizou o } \\
\text { exame de anemia (Juiz 12) }\end{array}$ & Ver comentário acima. \\
\hline
\end{tabular}


Tabela 6. Sugestões apresentadas pelos juízes para a melhoria do instrumento e as respectivas ações e comentários dos autores. (continuação).

\begin{tabular}{|c|c|c|}
\hline & Sugestões & Comentários/Ações \\
\hline $\begin{array}{l}\text { 6. O conforto da sala onde } \\
\text { fiquei esperando ser } \\
\text { chamado(a) para doar } \\
\text { sangue }\end{array}$ & $\begin{array}{l}\text { Nos serviços de hemoterapia, } \\
\text { há três salas de espera: } \\
\text { recepção, triagem e pré- } \\
\text { doação. (Juiz 7) }\end{array}$ & $\begin{array}{l}\text { Modificamos o texto para: “O } \\
\text { conforto da sala de pré- } \\
\text { doação, onde fiquei esperando } \\
\text { ser chamado(a) para doar } \\
\text { sangue”. }\end{array}$ \\
\hline $\begin{array}{l}\text { 7. A limpeza das salas que } \\
\text { eu estive antes de ser } \\
\text { chamado para coletar } \\
\text { sangue }\end{array}$ & SEM SUGESTÕES & - \\
\hline $\begin{array}{l}\text { 8. O tempo que eu tive que } \\
\text { esperar para ser } \\
\text { chamado(a) para entrar na } \\
\text { sala de coleta }\end{array}$ & $\begin{array}{l}\text { É importante deixar claro se é } \\
\text { desde o momento em que o } \\
\text { doador entrou no Hemocentro } \\
\text { ou após a triagem (Juiz 3) }\end{array}$ & $\begin{array}{l}\text { Modificamos o texto para: “O } \\
\text { tempo que eu tive que esperar } \\
\text { para ser chamado(a) para } \\
\text { entrar na sala de coleta, após a } \\
\text { triagem". }\end{array}$ \\
\hline $\begin{array}{l}\text { 9. A gentileza do } \\
\text { profissional que coletou o } \\
\text { meu sangue }\end{array}$ & $\begin{array}{l}\text { A clareza e gentileza do } \\
\text { profissional que coletou o meu } \\
\text { sangue (Juiz 2) }\end{array}$ & $\begin{array}{l}\text { Não é recomendado que um } \\
\text { único item contemple duas } \\
\text { coisas diferentes. }\end{array}$ \\
\hline $\begin{array}{l}\text { 10. A segurança que o } \\
\text { Hemocentro me passa } \\
\text { quanto ao material usado } \\
\text { para a coleta }\end{array}$ & $\begin{array}{l}\text { Utilizar uma linguagem mais } \\
\text { clara (Juiz 3) }\end{array}$ & $\begin{array}{l}\text { Modificamos o texto para: "A } \\
\text { segurança que o Hemocentro } \\
\text { me passa quanto ao material } \\
\text { usado para tirar sangue (na } \\
\text { coleta e nos testes)". }\end{array}$ \\
\hline $\begin{array}{l}\text { 11. O cuidado que eu sinto } \\
\text { estar recebendo, durante a } \\
\text { doação de sangue }\end{array}$ & SEM SUGESTÕES & - \\
\hline $\begin{array}{l}\text { 12. A higiene da sala de } \\
\text { coleta }\end{array}$ & SEM SUGESTÕES & - \\
\hline $\begin{array}{l}\text { 13. A atenção que o } \\
\text { profissional que coleta o } \\
\text { sangue tem naquilo que } \\
\text { está fazendo }\end{array}$ & $\begin{array}{l}\text { (naquilo que está fazendo) } \\
\text { substituir por no procedimento } \\
\text { que está realizando. (Juiz 6) }\end{array}$ & $\begin{array}{l}\text { Modificamos o texto para: "A } \\
\text { atenção que o profissional que } \\
\text { coleta o sangue tem no } \\
\text { procedimento que está } \\
\text { fazendo". }\end{array}$ \\
\hline $\begin{array}{l}\text { 14. O conforto da sala de } \\
\text { coleta }\end{array}$ & SEM SUGESTÕES & - \\
\hline
\end{tabular}


Tabela 6. Sugestões apresentadas pelos juízes para a melhoria do instrumento e as respectivas ações e comentários dos autores. (continuação).

\begin{tabular}{|c|c|c|}
\hline & Sugestões & Comentários/Ações \\
\hline $\begin{array}{l}\text { 15. O tempo gasto durante } \\
\text { a doação de sangue, } \\
\text { quando já estava na sala } \\
\text { de coleta }\end{array}$ & $\begin{array}{l}\text { Não seria mais claro: O tempo } \\
\text { gasto para a doação de sangue } \\
\text { (coleta) (Juiz 6) }\end{array}$ & $\begin{array}{l}\text { Modificamos o texto para: “O } \\
\text { tempo que passei no } \\
\text { Hemocentro, desde a recepção } \\
\text { até terminar a doação de } \\
\text { sangue". }\end{array}$ \\
\hline $\begin{array}{l}\text { 16. A limpeza da copa } \\
\text { (onde servem o lanche) }\end{array}$ & SEM SUGESTÕES & - \\
\hline $\begin{array}{l}\text { 17. As explicações que os } \\
\text { profissionais me dão em } \\
\text { relação a tudo que eu } \\
\text { quero entender }\end{array}$ & $\begin{array}{l}\text { A frase "a tudo que quero } \\
\text { saber" parece não soar bem. } \\
\text { Sugiro: as explicações que os } \\
\text { profissionais me dão com } \\
\text { relação a doação de sangue. } \\
\text { (Juiz 6) }\end{array}$ & $\begin{array}{c}\text { Para a avaliação da satisfação } \\
\text { da percepção de acolhimento } \\
\text { do doador, se faz necessário } \\
\text { que ele seja atendido a } \\
\text { questões que vão além do } \\
\text { processo de doação de sangue, } \\
\text { como sua saúde e integridade. }\end{array}$ \\
\hline $\begin{array}{l}\text { 18. O lanche que me } \\
\text { ofereceram depois da } \\
\text { doação }\end{array}$ & SEM SUGESTÕES & - \\
\hline $\begin{array}{l}\text { 19. A quantidade de } \\
\text { profissionais disponíveis } \\
\text { para me atender }\end{array}$ & $\begin{array}{l}\text { Não deveria existir essa } \\
\text { pergunta, devido ao } \\
\text { revezamento da escala (Juiz } \\
\text { 11) }\end{array}$ & $\begin{array}{c}\text { O que está sendo avaliado não } \\
\text { é a quantidade de profissionais } \\
\text { disponíveis, mas a percepção } \\
\text { do doador quanto à } \\
\text { disponibilidade de pessoas } \\
\text { necessária à sua satisfação. }\end{array}$ \\
\hline $\begin{array}{l}\text { 20. A competência } \\
\text { profissional das pessoas } \\
\text { que trabalham no } \\
\text { Hemocentro }\end{array}$ & $\begin{array}{l}\text { Já contemplada na } 17 \text {. Trocar } \\
\text { por "A solução de problemas } \\
\text { pelos profissionais que } \\
\text { trabalham no Hemocentro" } \\
\text { (Juiz 2) }\end{array}$ & $\begin{array}{l}\text { A questão } 17 \text { inclui percepções } \\
\text { de acolhimento, enquanto a } \\
\text { questão } 20 \text { diz respeito a } \\
\text { questões técnicas. }\end{array}$ \\
\hline $\begin{array}{l}\text { 21. O atendimento do } \\
\text { funcionário que trabalha } \\
\text { na copa }\end{array}$ & $\begin{array}{c}\text { O serviço prestado pelo } \\
\text { funcionário que me atendeu } \\
\text { na copa (Juiz } 1 \text { ) }\end{array}$ & $\begin{array}{c}\text { O “serviço prestado" pode } \\
\text { incluir a realização de tarefas } \\
\text { pelo funcionário que } \\
\text { extrapolam aquelas } \\
\text { desempenhadas ao contato } \\
\text { com o doador de sangue, que } \\
\text { são o objetivo de avaliação de } \\
\text { satisfação. }\end{array}$ \\
\hline
\end{tabular}


Tabela 6. Sugestões apresentadas pelos juízes para a melhoria do instrumento e as respectivas ações e comentários dos autores. (continuação)

\section{Sugestões}

Comentários/Ações

22. A disponibilidade dos profissionais em me ouvir, SEM SUGESTÕES em qualquer momento

23. Os horários de atendimento do Hemocentro ao doador de SEM SUGESTÕES sangue

24. O esforço dos profissionais para eu me sentir à vontade

\section{Contemplada na 17 e na 20} (Juiz 2)

A questão 24 contempla uma percepção diferente daquela especificada no item 17 , mas a sugestão será novamente testada de acordo com a correlação entre os itens encontrada na etapa posterior, em uma amostra de doadores que fará o pré-teste do instrumento.

25. $O$ respeito com que as pessoas me tratam no SEM SUGESTÕES

Hemocentro 


\section{Estrutura dos domínios}

Os juízes foram convidados a classificar cada item do instrumento conforme seu domínio: acessibilidade/conveniência (AC), aspectos técnicos (AT) e aspectos interpessoais (AI). Foi preparado um documento impresso, contendo os itens do instrumento, e um quadro com as seguintes definições para que os juízes compreendessem o significado de cada domínio:

Acesso/conveniência: Trata a capacidade do Hemocentro em prover os serviços necessários no tempo e lugar adequados aos doadores.

Aspectos técnicos: Relacionam-se à satisfação do doador diante de situações de interação com o ambiente físico e organizacional do Hemocentro.

Aspectos interpessoais: Relacionam-se à satisfação do doador quando em contato com os funcionários do Hemocentro.

A Tabela 7 mostra como os juízes classificaram cada item conforme os domínios originais do instrumento, com os respectivos valores de FVI (factorial validity index, FVI, Rubio et al., 2003), que determinam o grau em que os juízes corretamente associam os itens aos seus respectivos domínios.

No questionário proposto, os itens originalmente concebidos para o domínio acesso/conveniência são, segundo a numeração da Tabela 7: 1, 4, 8, 15, 18 e 23. O domínio aspectos técnicos é composto pelos itens: $6,7,10,12,14,16,19$ e 20 . O domínio aspectos interpessoais é composto pelos itens: 2, 3, 5, 9, 11, 13, 17, 21, 22, 24 e 25. Na Tabela 7, observam-se valores de FVI relativamente baixos para os itens 4, 6, 14 e 15. 
Tabela 7. Resultados da análise de estrutura de domínios do instrumento.

\begin{tabular}{|c|c|c|c|c|c|c|}
\hline & $A C$ & AT & Al & AT e Al & Nenhum & FVI \\
\hline $\begin{array}{l}\text { 1. A facilidade para se chegar ao } \\
\text { Hemocentro }\end{array}$ & 9 & 2 & 1 & 1 & 0 & 0,75 \\
\hline $\begin{array}{l}\text { 2. } O \text { atendimento do pessoal da } \\
\text { recepção }\end{array}$ & 2 & 0 & 9 & 0 & 0 & 0,75 \\
\hline $\begin{array}{l}\text { 3. A gentileza do profissional que fez a } \\
\text { entrevista antes da doação }\end{array}$ & 1 & 1 & 10 & 0 & 0 & 0,83 \\
\hline $\begin{array}{l}\text { 4. O tempo gasto durante a entrevista, } \\
\text { antes da doação de sangue }\end{array}$ & 5 & 5 & 2 & 0 & 0 & 0,42 \\
\hline $\begin{array}{l}\text { 5. O atendimento do profissional que } \\
\text { mediu a minha pressão antes da } \\
\text { entrevista }\end{array}$ & 2 & 1 & 7 & 1 & 1 & 0,58 \\
\hline $\begin{array}{l}\text { 6. O conforto da sala onde fiquei } \\
\text { esperando ser chamado(a) para doar } \\
\text { sangue }\end{array}$ & 7 & 3 & 1 & 0 & 1 & 0,25 \\
\hline $\begin{array}{l}\text { 7. A limpeza das salas que eu estive } \\
\text { antes de ser chamado para coletar } \\
\text { sangue }\end{array}$ & 5 & 6 & 1 & 0 & 0 & 0,50 \\
\hline $\begin{array}{l}\text { 8. O tempo que eu tive que esperar } \\
\text { para ser chamado(a) para entrar na } \\
\text { sala de coleta }\end{array}$ & 6 & 0 & 0 & 0 & 0 & 0,50 \\
\hline $\begin{array}{l}\text { 9. A gentileza do profissional que } \\
\text { coletou o meu sangue }\end{array}$ & 1 & 1 & 10 & 0 & 0 & 0,83 \\
\hline $\begin{array}{l}\text { 10. A segurança que o Hemocentro } \\
\text { me passa quanto ao material usado } \\
\text { para a coleta }\end{array}$ & 3 & 9 & 0 & 0 & 0 & 0,75 \\
\hline $\begin{array}{l}\text { 11. O cuidado que eu sinto estar } \\
\text { recebendo, durante a doação de } \\
\text { sangue }\end{array}$ & 0 & 1 & 10 & 0 & 1 & 0,83 \\
\hline 12. A higiene da sala de coleta & 3 & 8 & 1 & 0 & 0 & 0,67 \\
\hline $\begin{array}{l}\text { 13. A atenção que o profissional que } \\
\text { coleta o sangue tem naquilo que está } \\
\text { fazendo }\end{array}$ & 1 & 5 & 6 & 0 & 0 & 0,50 \\
\hline 14. O conforto da sala de coleta & 7 & 3 & 2 & 0 & 0 & 0,25 \\
\hline $\begin{array}{l}\text { 15. O tempo gasto durante a doação } \\
\text { de sangue, quando já estava na sala } \\
\text { de coleta }\end{array}$ & 3 & 9 & 0 & 0 & 0 & 0,25 \\
\hline $\begin{array}{l}\text { 16. A limpeza da copa (onde servem o } \\
\text { lanche) }\end{array}$ & 4 & 7 & 1 & 0 & 0 & 0,58 \\
\hline
\end{tabular}


Tabela 7. Resultados da análise de estrutura de domínios do instrumento (continuação).

\begin{tabular}{|c|c|c|c|c|c|c|}
\hline & $A C$ & AT & Al & AT e Al & Nenhum & FVI \\
\hline $\begin{array}{l}\text { 17. As explicações que os profissionais } \\
\text { me dão em relação a tudo que eu } \\
\text { quero entender }\end{array}$ & 1 & 5 & 6 & 0 & 0 & 0,50 \\
\hline $\begin{array}{l}\text { 18. O lanche que me ofereceram } \\
\text { depois da doação }\end{array}$ & 7 & 2 & 2 & 0 & 1 & 0,58 \\
\hline $\begin{array}{l}\text { 19. A quantidade de profissionais } \\
\text { disponíveis para me atender }\end{array}$ & 4 & 7 & 1 & 0 & 0 & 0,58 \\
\hline $\begin{array}{l}\text { 20. A competência profissional das } \\
\text { pessoas que trabalham no } \\
\text { Hemocentro }\end{array}$ & 2 & 7 & 2 & 0 & 1 & 0,58 \\
\hline $\begin{array}{l}\text { 21. O atendimento do funcionário que } \\
\text { trabalha na copa }\end{array}$ & 1 & 2 & 9 & 0 & 0 & 0,75 \\
\hline $\begin{array}{l}\text { 22. A disponibilidade dos profissionais } \\
\text { em me ouvir, em qualquer momento }\end{array}$ & 0 & 3 & 7 & 0 & 1 & 0,58 \\
\hline $\begin{array}{l}\text { 23. Os horários de atendimento do } \\
\text { Hemocentro ao doador de sangue }\end{array}$ & 8 & 4 & 0 & 0 & 0 & 0,67 \\
\hline $\begin{array}{l}\text { 24. O esforço dos profissionais para eu } \\
\text { me sentir à vontade }\end{array}$ & 0 & 1 & 11 & 0 & 0 & 0,92 \\
\hline $\begin{array}{l}\text { 25. O respeito com que as pessoas me } \\
\text { tratam no Hemocentro }\end{array}$ & 0 & 1 & 9 & 1 & 1 & 0,75 \\
\hline
\end{tabular}

AC: acessibilidade/conveniência, AT: aspectos técnicos, AI: aspectos interpessoais.

\section{Abrangência da medida}

A Tabela 8 mostra as respostas dos juízes à pergunta "Quais itens você recomenda excluir do instrumento de satisfação do doador de sangue?" e os correspondentes comentários dos autores. 
Tabela 8. Itens que os juízes recomendam excluir do questionário.

\begin{tabular}{|c|c|c|}
\hline Juiz & Itens & Comentários dos autores \\
\hline 2 & 20 e 24 & $\begin{array}{l}\text { Acredita-se que as questões } 17,20 \text { e } 24 \\
\text { dirigem-se a percepções diferentes da } \\
\text { satisfação. As questões } 17 \text { e } 24 \text { incluem } \\
\text { percepções de acolhimento, enquanto a } \\
\text { questão } 20 \text { diz respeito a questões } \\
\text { técnicas. Entretanto, a sugestão de } \\
\text { exclusão será novamente testada de } \\
\text { acordo com a correlação entre os itens } \\
17,20 \text { e } 24 \text {, encontrada na etapa } \\
\text { posterior, em uma amostra de doadores } \\
\text { que fará o pré-teste do instrumento. }\end{array}$ \\
\hline 6 & $\begin{array}{l}\text { Acredito que o item } 22 \text { não se seja } \\
\text { necessário. uma vez que esse tipo de } \\
\text { questionamento já foi feito em outras } \\
\text { palavras. }\end{array}$ & $\begin{array}{l}\text { A questão } 22 \text { será mantida na etapa } \\
\text { seguinte da pesquisa, por tratar um } \\
\text { aspecto do acolhimento que tem grande } \\
\text { relevância, mas a sugestão de exclusão } \\
\text { será novamente testada de acordo com a } \\
\text { correlação entre os itens } 17,20,22 \text { e } 24 \text {, } \\
\text { encontrada na etapa posterior, em uma } \\
\text { amostra de doadores que fará o pré- } \\
\text { teste do instrumento. }\end{array}$ \\
\hline 9 & $\begin{array}{l}\text { Excluiria o item } 20 \text {, pois seria sempre } \\
\text { uma interpretação difícil de um usuário } \\
\text { do sistema avaliar a competência de um } \\
\text { profissional da área técnica. }\end{array}$ & $\begin{array}{l}\text { O que está sendo avaliado não é a } \\
\text { competência técnica do profissional, mas } \\
\text { a satisfação do doador quando ao serviço } \\
\text { prestado. O instrumento é dirigido } \\
\text { exclusivamente à percepção do usuário } \\
\text { do serviço, sem que isso seja } \\
\text { considerado um indicador de } \\
\text { competência de um profissional. }\end{array}$ \\
\hline 11 & Itens 19 e 22 & $\begin{array}{l}\text { As questões } 19 \text { e } 22 \text { serão mantidas na } \\
\text { etapa seguinte da pesquisa, mas a } \\
\text { sugestão de exclusão será novamente } \\
\text { testada de acordo com a correlação com } \\
\text { outros itens do instrumento. }\end{array}$ \\
\hline
\end{tabular}

A Tabela 9 mostra as respostas dos juízes à pergunta "Quais outros itens você sugere incluir no instrumento para se obter uma medida da satisfação do doador de sangue?" e os correspondentes comentários dos autores. 
Tabela 9. Itens que os juízes recomendam incluir no questionário.

\begin{tabular}{|c|c|c|}
\hline Juiz & Sugestão & Comentários dos autores \\
\hline 1 & $\begin{array}{l}\text { Sugiro incluir uma questão para avaliar } \\
\text { a maneira que o doador foi } \\
\text { abordado/convidado para realizar a } \\
\text { doação de sangue. Sugiro incluir uma } \\
\text { questão para avaliar a } \\
\text { clareza/entendimento do material } \\
\text { escrito/informativo que foi entregue } \\
\text { nas etapas da doação. }\end{array}$ & $\begin{array}{l}\text { A avaliação da maneira que o doador é } \\
\text { abordado ou convidado é importante, } \\
\text { mas pode extrapolar uma pesquisa de } \\
\text { satisfação, dado que este procedimento } \\
\text { envolve outras dimensões. } \\
\text { A avaliação da clareza/entendimento do } \\
\text { material escrito/informativo pode estar } \\
\text { relacionada à qualidade do material, e } \\
\text { não diretamente à satisfação do doador } \\
\text { (que pode valorizar ou não tal material). }\end{array}$ \\
\hline 2 & $\begin{array}{l}\text { Manteria algumas linhas em branco } \\
\text { para que o doador, no caso de assinalar } \\
\text { as opções "muito insatisfeito" ou } \\
\text { "insatisfeito", possa, se desejar, explicar } \\
\text { o motivo e/ou dar uma } \\
\text { opinião/sugestão de melhoria para esta } \\
\text { opção assinalada }\end{array}$ & $\begin{array}{c}\text { O doador deve ser motivado, nesses } \\
\text { casos, a utilizar a caixa de sugestões, de } \\
\text { forma que o questionário de satisfação } \\
\text { não substitua os demais procedimentos } \\
\text { de gestão da qualidade adotados pela } \\
\text { instituição. }\end{array}$ \\
\hline 3 & Cuidados pós-doação & \\
\hline 6 & $\begin{array}{l}\text { Sugiro um item com relação a } \\
\text { entrevista, a confiança no triador. }\end{array}$ & $\begin{array}{l}\text { A confiança no profissional que faz a } \\
\text { triagem é importante, mas pode não ser } \\
\text { um aspecto da satisfação, apesar de } \\
\text { estar relacionado a ela. }\end{array}$ \\
\hline 7 & $\begin{array}{l}\text { 1. O Material de entretenimento } \\
\text { durante a espera é satisfatório? } 2 \text {. O } \\
\text { acesso à rede wifi durante a espera foi } \\
\text { satisfatório? 3. O estacionamento nas } \\
\text { imediações foi fácil e seguro? } 4 \text {. } \\
\text { Quando necessário, o acesso ao médico } \\
\text { da unidade foi fácil e sem burocracia? } \\
\text { 5. Considera satisfatório o tempo para } \\
\text { pegar a carteirinha de doador? } 6 . \\
\text { Considera satisfatória a comunicação do } \\
\text { Hemocentro por correio, e-mail, } \\
\text { whatsapp, face e outros? 7. Considera } \\
\text { eficiente a comunicação de campanhas } \\
\text { ou de mudanças de horário de } \\
\text { atendimento? 8. Considera satisfatório } \\
\text { o serviço de agendamento de doação? }\end{array}$ & $\begin{array}{l}\text { Os itens sugeridos são fundamentais, } \\
\text { mas a maioria poderia ser estudada em } \\
\text { uma pesquisa específica sobre as } \\
\text { estratégias de comunicação com o } \\
\text { doador de sangue. }\end{array}$ \\
\hline
\end{tabular}


Tabela 9. Itens que os juízes recomendam incluir no questionário (continuação).

\begin{tabular}{|c|c|c|}
\hline Juiz & Sugestão & Comentários dos autores \\
\hline 11 & $\begin{array}{l}\text { Uma questão que a gente percebe que } \\
\text { é bastante preocupante para o doador } \\
\text { é quando ele traz acompanhante } \\
\text { criança, ele fica inseguro ao ter que } \\
\text { deixá-la na recepção, uma vez que em } \\
\text { todos os hemocentros tem locais } \\
\text { próprios para crianças (brinquedoteca). }\end{array}$ & $\begin{array}{l}\text { Não é comum em pesquisas de satisfação } \\
\text { abordar aspectos que envolvem uma } \\
\text { estrutura que não está em planejamento } \\
\text { fazer incrementos ou mudanças. Por } \\
\text { exemplo, não é útil abordar a } \\
\text { necessidade de uma brinquedoteca } \\
\text { quando não há um planejamento para } \\
\text { construí-la. A instalação de uma } \\
\text { brinquedoteca envolveria uma pesquisa } \\
\text { sobre demandas do serviço, e não } \\
\text { necessariamente sobre a satisfação. }\end{array}$ \\
\hline 12 & $\begin{array}{l}\text { O tempo que eu tive que esperar para } \\
\text { ser chamado(a) para entrar na sala de } \\
\text { entrevista } \\
\text { A aparência dos profissionais que me } \\
\text { atenderam }\end{array}$ & \\
\hline
\end{tabular}

\section{Itens modificados}

A Tabela 10 apresenta um resumo da validação de conteúdo do instrumento, com as decisões tomadas para cada item (modificar ou não). Foram então modificados os textos dos itens 4, 5, 6, 8, 10, 13 e 15. As mudanças são apresentadas na Tabela 11.

A Figura 4 mostra a segunda página da nova versão do instrumento, com as modificações efetuadas nesta etapa. Foi acrescentada uma coluna para os respondentes, na próxima Etapa da pesquisa, marcar caso não entendessem um dado item. A primeira página do instrumento (frente) não foi modificada. 
Tabela 10. Resumo da validação de conteúdo.

\begin{tabular}{|c|c|c|c|c|c|c|}
\hline Item & CVR & FVI & $\begin{array}{c}\text { Necessidade } \\
\text { de revisão }\end{array}$ & $\begin{array}{c}\text { Sugestões } \\
\text { de mudança }\end{array}$ & $\begin{array}{c}\text { Sugestões } \\
\text { de exclusão }\end{array}$ & Conclusão \\
\hline 1 & 0,00 & 0,75 & $\operatorname{sim}$ & $\operatorname{sim}$ & não & Revisto, mas não modificado \\
\hline 2 & 1,00 & 0,75 & $\operatorname{sim}$ & $\operatorname{sim}$ & não & Revisto, mas não modificado \\
\hline 3 & 0,83 & 0,83 & $\operatorname{sim}$ & $\operatorname{sim}$ & não & Revisto, mas não modificado \\
\hline 4 & 0,50 & 0,42 & $\operatorname{sim}$ & $\operatorname{sim}$ & não & Item modificado \\
\hline 5 & 0,83 & 0,58 & $\operatorname{sim}$ & $\operatorname{sim}$ & não & Item modificado \\
\hline 6 & 0,50 & 0,25 & $\operatorname{sim}$ & $\operatorname{sim}$ & não & Item modificado \\
\hline 7 & 1,00 & 0,50 & não & não & não & APROVADO sem revisão \\
\hline 8 & 0,67 & 0,50 & $\operatorname{sim}$ & $\operatorname{sim}$ & não & Item modificado \\
\hline 9 & 1,00 & 0,83 & $\operatorname{sim}$ & $\operatorname{sim}$ & não & Revisto, mas não modificado \\
\hline 10 & 1,00 & 0,75 & $\operatorname{sim}$ & $\operatorname{sim}$ & não & Item modificado \\
\hline 11 & 0,67 & 0,83 & $\operatorname{sim}$ & não & não & Revisto, mas não modificado \\
\hline 12 & 1,00 & 0,67 & não & não & não & APROVADO sem revisão \\
\hline 13 & 1,00 & 0,50 & $\operatorname{sim}$ & $\operatorname{sim}$ & não & Item modificado \\
\hline 14 & 0,83 & 0,25 & não & não & não & APROVADO sem revisão \\
\hline 15 & 0.33 & 0,25 & $\operatorname{sim}$ & $\operatorname{sim}$ & não & Item modificado \\
\hline 16 & 1,00 & 0,58 & não & não & não & APROVADO sem revisão \\
\hline 17 & 1,00 & 0,50 & $\operatorname{sim}$ & $\operatorname{sim}$ & não & Revisto, mas não modificado \\
\hline 18 & 0,17 & 0,58 & $\operatorname{sim}$ & não & não & Revisto, mas não modificado \\
\hline 19 & 0,50 & 0,58 & $\operatorname{sim}$ & $\operatorname{sim}$ & $\operatorname{sim}$ & Revisto, mas não modificado \\
\hline 20 & 0,67 & 0,58 & $\operatorname{sim}$ & $\operatorname{sim}$ & $\operatorname{sim}$ & Revisto, mas não modificado \\
\hline 21 & 0,17 & 0,75 & não & $\operatorname{sim}$ & não & Revisto, mas não modificado \\
\hline 22 & 0,33 & 0,58 & não & não & $\operatorname{sim}$ & Revisto, mas não modificado \\
\hline 23 & 0,83 & 0,67 & não & não & não & APROVADO sem revisão \\
\hline 24 & 0,50 & 0,92 & não & $\operatorname{sim}$ & $\operatorname{sim}$ & Revisto, mas não modificado \\
\hline 25 & 1,00 & 0,75 & não & não & não & APROVADO sem revisão \\
\hline
\end{tabular}


Tabela 11. Itens modificados após a validação de conteúdo.

\section{Item original}

4. O tempo gasto durante a entrevista, antes da doação de sangue

5. $O$ atendimento do profissional que mediu a minha pressão antes da entrevista

6. O conforto da sala onde fiquei esperando ser chamado(a) para doar sangue

8. O tempo que eu tive que esperar para ser chamado(a) para entrar na sala de coleta

10. A segurança que o Hemocentro me passa quanto ao material usado para a coleta

13. A atenção que o profissional que coleta o sangue tem naquilo que está fazendo

15. O tempo gasto durante a doação de sangue, quando já estava na sala de coleta

\section{Item modificado}

4. O tempo que eu tive que esperar para ser chamado para a entrevista, depois da triagem

5. $O$ atendimento do profissional que me atendeu na pré-triagem (que mediu a minha pressão antes da entrevista)

6. O conforto da sala de pré-doação, onde fiquei esperando ser chamado(a) para doar sangue

8. O tempo que eu tive que esperar para ser chamado(a) para entrar na sala de coleta, após a triagem

10. A segurança que o Hemocentro me passa quanto ao material usado para tirar sangue (na coleta e nos testes)

13. A atenção que o profissional que coleta o sangue tem no procedimento que está fazendo

15. O tempo todo que passei no Hemocentro, desde a recepção até terminar a doação de sangue 


\begin{tabular}{|c|c|c|c|c|c|c|}
\hline & $\begin{array}{l}\text { Muito } \\
\text { insatisfeito }\end{array}$ & Insatisfeito & Regular & Satisfeito & $\begin{array}{l}\text { Muito } \\
\text { satisfeito }\end{array}$ & $\begin{array}{c}\text { NÄO } \\
\text { ENIENDI }\end{array}$ \\
\hline A facilidade para se chegar ao Hemocentro & $\square$ & $\square$ & $\square$ & $\square$ & $\square$ & \\
\hline O atendimento do pessoal da recepção & $\square$ & $\square$ & $\square$ & $\square$ & $\square$ & \\
\hline $\begin{array}{l}\text { O atendimento do profissional que me } \\
\text { atendeu na pré-triagem (que mediu a } \\
\text { minha pressão antes da entrevista) }\end{array}$ & $\square$ & $\square$ & $\square$ & $\square$ & $\square$ & \\
\hline $\begin{array}{l}\text { O tempo que eu tive que esperar para ser } \\
\text { chamado para a entrevista, depois da pré- } \\
\text { triagem }\end{array}$ & $\square$ & $\square$ & $\square$ & $\square$ & $\square$ & \\
\hline $\begin{array}{l}\text { A gentileza do profissional que fez a } \\
\text { entrevista antes da doação }\end{array}$ & $\square$ & $\square$ & $\square$ & $\square$ & $\square$ & \\
\hline $\begin{array}{l}\text { O conforto da sala onde fiquei esperando } \\
\text { ser chamado(a) para doar sangue }\end{array}$ & $\square$ & $\square$ & $\square$ & $\square$ & $\square$ & \\
\hline $\begin{array}{l}\text { A limpeza das salas que eu estive antes de } \\
\text { ser chamado para coletar sangue }\end{array}$ & $\square$ & $\square$ & $\square$ & $\square$ & $\square$ & \\
\hline $\begin{array}{l}\text { O tempo que eu tive que esperar para ser } \\
\text { chamado(a) para entrar na sala de coleta }\end{array}$ & $\square$ & $\square$ & $\square$ & $\square$ & $\square$ & \\
\hline $\begin{array}{l}\text { A gentileza do profissional que coletou o } \\
\text { meu sangue }\end{array}$ & $\square$ & $\square$ & $\square$ & $\square$ & $\square$ & \\
\hline $\begin{array}{l}\text { A segurança que o Hemocentro me passa } \\
\text { quanto ao material usado para tirar sangue } \\
\text { (na coleta e nos testes) }\end{array}$ & $\square$ & $\square$ & $\square$ & $\square$ & $\square$ & \\
\hline $\begin{array}{l}\text { O cuidado que eu sinto estar recebendo, } \\
\text { durante a doação de sangue }\end{array}$ & $\square$ & $\square$ & $\square$ & $\square$ & $\square$ & \\
\hline A higiene da sala de coleta & $\square$ & $\square$ & $\square$ & $\square$ & $\square$ & \\
\hline $\begin{array}{l}\text { A atenção que o profissional que coleta } \circ \\
\text { sangue tem naquilo que está fazendo }\end{array}$ & $\square$ & $\square$ & $\square$ & $\square$ & $\square$ & \\
\hline O conforto da sala de coleta & $\square$ & $\square$ & $\square$ & $\square$ & $\square$ & \\
\hline A limpeza da copa (onde servem o lanche) & $\square$ & $\square$ & $\square$ & $\square$ & $\square$ & \\
\hline $\begin{array}{l}\text { As explicações que os profissionais me dão } \\
\text { em relação a tudo que eu quero entender }\end{array}$ & $\square$ & $\square$ & $\square$ & $\square$ & $\square$ & \\
\hline $\begin{array}{l}\text { O lanche que me ofereceram depois da } \\
\text { doação }\end{array}$ & $\square$ & $\square$ & $\square$ & $\square$ & $\square$ & \\
\hline $\begin{array}{l}\text { A quantidade de profissionais disponiveis } \\
\text { para me atender }\end{array}$ & $\square$ & $\square$ & $\square$ & $\square$ & $\square$ & \\
\hline $\begin{array}{l}\text { A competência profissional das pessoas que } \\
\text { trabalham no Hemocentro }\end{array}$ & $\square$ & $\square$ & $\square$ & $\square$ & $\square$ & \\
\hline $\begin{array}{l}\text { O atendimento do funcionário que trabalha } \\
\text { na copa }\end{array}$ & $\square$ & $\square$ & $\square$ & $\square$ & $\square$ & \\
\hline $\begin{array}{l}\text { O tempo todo que passei no Hemocentro, } \\
\text { desde a recepção até terminar a doação de } \\
\text { sangue }\end{array}$ & $\square$ & $\square$ & $\square$ & $\square$ & $\square$ & \\
\hline $\begin{array}{l}\text { A disponibilidade dos profissionais em me } \\
\text { ouvir, em qualquer momento }\end{array}$ & $\square$ & $\square$ & $\square$ & $\square$ & $\square$ & \\
\hline $\begin{array}{l}\text { Os horários de atendimento do } \\
\text { Hemocentro ao doador de sangue }\end{array}$ & $\square$ & $\square$ & $\square$ & $\square$ & $\square$ & \\
\hline $\begin{array}{l}\text { O esforço dos profissionais para eu me } \\
\text { sentir à vontade }\end{array}$ & $\square$ & $\square$ & $\square$ & $\square$ & $\square$ & \\
\hline $\begin{array}{l}\text { O respeito com que as pessoas me tratam } \\
\text { no Hemocentro }\end{array}$ & $\square$ & $\square$ & $\square$ & $\square$ & $\square$ & \\
\hline
\end{tabular}

Agradecemos a sua participação!

Figura 4. Questionário de satisfação do doador (verso), com as modificações realizadas durante a etapa de validação de conteúdo. 


\subsection{Etapa 3: Pré-teste do instrumento}

Tabela 12. Perfil dos doadores que participaram do pré-teste do instrumento $(n=114)$.

\begin{tabular}{|c|c|c|c|}
\hline Variável & & $n$ & $\%$ \\
\hline \multirow[t]{2}{*}{ Sexo } & Feminino & 50 & 44,3 \\
\hline & Masculino & 63 & 55,7 \\
\hline \multirow[t]{5}{*}{ Quantas vezes já doou sangue } & Primeira vez & 20 & 17,7 \\
\hline & Segunda vez & 24 & 21,3 \\
\hline & 3 a 5 & 18 & 15,9 \\
\hline & 6 a 10 & 19 & 16,8 \\
\hline & Mais de 10 & 32 & 28,3 \\
\hline \multirow[t]{3}{*}{ Quando doou sangue pela última vez } & Primeira vez & 20 & 18,5 \\
\hline & Há menos de um ano & 49 & 46,3 \\
\hline & Há mais de um ano & 38 & 35,2 \\
\hline \multirow[t]{6}{*}{ Escolaridade } & Sem escolaridade & 0 & 0 \\
\hline & Fundamental I completo & 4 & 3,5 \\
\hline & Fundamental II completo & 10 & 8,8 \\
\hline & Ensino médio & 62 & 54,4 \\
\hline & Superior & 29 & 25,4 \\
\hline & Pós-graduação & 9 & 7,9 \\
\hline \multirow[t]{4}{*}{ Motivo da doação } & Solicitação do Hemocentro & 4 & 3,6 \\
\hline & Para um familiar ou amigo & 6 & 5,3 \\
\hline & Manter o estoque & 99 & 88,4 \\
\hline & Doação autóloga & 3 & 2,7 \\
\hline \multirow[t]{6}{*}{ Como chegou ao Hemocentro } & De carro próprio & 79 & 69,9 \\
\hline & Táxi/Uber & 3 & 2,6 \\
\hline & Ônibus & 10 & 8,9 \\
\hline & A pé & 13 & 11,5 \\
\hline & De carona & 8 & 7,1 \\
\hline & Outra forma & & \\
\hline \multirow[t]{3}{*}{ Facilidade para encontrar vaga para estacionar } & Sim & 63 & 57,3 \\
\hline & Não & 28 & 25,4 \\
\hline & Não veio de carro & 19 & 17,3 \\
\hline \multirow[t]{6}{*}{ Uso de redes sociais } & Whatsapp & 105 & 92,1 \\
\hline & Facebook & 84 & 73,7 \\
\hline & Instagram & 33 & 29,0 \\
\hline & Youtube & 22 & 19,3 \\
\hline & Google+ & 5 & 4,4 \\
\hline & Linkedin & 1 & 0,9 \\
\hline
\end{tabular}


Participaram da etapa de pré-teste do instrumento 114 doadores de sangue, com idades de 18 a 61 anos (média de 33 anos, desvio padrão 9,7 anos). A Tabela 12 mostra um perfil destes doadores de sangue. As somas das frequências apresentadas na Tabela 12 nem sempre resultam em $n=114$ dado que algumas variáveis não foram respondidas.

A Tabela 13 exibe as frequências de respostas aos itens relativos aos atributos da satisfação, e ao item de satisfação geral. Observa-se que apenas um doador declarou não entender os itens 1 e 4 do instrumento.

Tabela 13. Pré-teste do instrumento, frequências de respostas aos itens relativos aos atributos da satisfação $(n=114)$.

\begin{tabular}{|c|c|c|c|c|c|c|}
\hline & 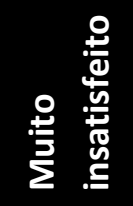 & 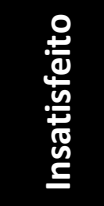 & 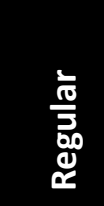 & 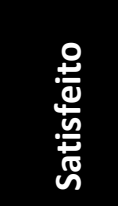 & 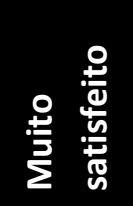 & 일 \\
\hline Satisfação geral & $\begin{array}{c}18 \\
(15,8)\end{array}$ & 0 & 0 & $\begin{array}{c}13 \\
(11,4)\end{array}$ & $\begin{array}{c}83 \\
(72,8)\end{array}$ & - \\
\hline $\begin{array}{l}\text { 1. A facilidade para se chegar ao } \\
\text { Hemocentro }\end{array}$ & $\begin{array}{c}9 \\
(8,0)\end{array}$ & $\begin{array}{c}1 \\
(0,9)\end{array}$ & $\begin{array}{c}7 \\
(6,2)\end{array}$ & $\begin{array}{c}42 \\
(37,2)\end{array}$ & $\begin{array}{c}53 \\
(46,9)\end{array}$ & $\begin{array}{c}1 \\
(0,9)\end{array}$ \\
\hline $\begin{array}{l}\text { 2. O atendimento do pessoal da } \\
\text { recepção }\end{array}$ & $\begin{array}{c}9 \\
(7,9)\end{array}$ & 0 & $\begin{array}{c}7 \\
(6,1)\end{array}$ & $\begin{array}{c}24 \\
(21,0)\end{array}$ & $\begin{array}{c}74 \\
(64,9)\end{array}$ & 0 \\
\hline $\begin{array}{l}\text { 3. A gentileza do profissional que } \\
\text { fez a entrevista antes da doação }\end{array}$ & $\begin{array}{c}10 \\
(8,8)\end{array}$ & 0 & 0 & $\begin{array}{c}26 \\
(22,8)\end{array}$ & $\begin{array}{c}78 \\
(68,4)\end{array}$ & 0 \\
\hline $\begin{array}{l}\text { 4. O tempo gasto durante a } \\
\text { entrevista, antes da doação de } \\
\text { sangue }\end{array}$ & $\begin{array}{c}10 \\
(8,8)\end{array}$ & $\begin{array}{c}1 \\
(0,9)\end{array}$ & $\begin{array}{c}6 \\
(5,3)\end{array}$ & $\begin{array}{c}35 \\
(30,7)\end{array}$ & $\begin{array}{c}61 \\
(53,5)\end{array}$ & $\begin{array}{c}1 \\
(0,9)\end{array}$ \\
\hline $\begin{array}{l}\text { 5. } 0 \text { atendimento do profissional } \\
\text { que mediu a minha pressão antes } \\
\text { da entrevista }\end{array}$ & $\begin{array}{c}10 \\
(8,8)\end{array}$ & 0 & 0 & $\begin{array}{c}31 \\
(27,2)\end{array}$ & $\begin{array}{c}73 \\
(64,0)\end{array}$ & 0 \\
\hline $\begin{array}{l}\text { 6. O conforto da sala onde fiquei } \\
\text { esperando ser chamado(a) para } \\
\text { doar sangue }\end{array}$ & $\begin{array}{c}10 \\
(8,8)\end{array}$ & 0 & $\begin{array}{c}2 \\
(1,8)\end{array}$ & $\begin{array}{c}32 \\
(28,1)\end{array}$ & $\begin{array}{c}70 \\
(61,4)\end{array}$ & 0 \\
\hline
\end{tabular}


Tabela 13. Pré-teste do instrumento, frequências de respostas aos itens relativos aos atributos da satisfação $(n=114)$. (continuação).

\begin{tabular}{|c|c|c|c|c|c|c|}
\hline & 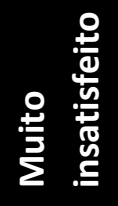 & 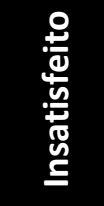 & 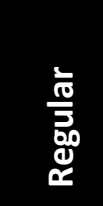 & 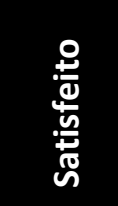 & 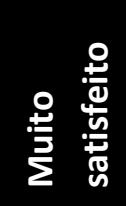 & 일 \\
\hline $\begin{array}{l}\text { 7. A limpeza das salas que eu } \\
\text { estive antes de ser chamado para } \\
\text { coletar sangue }\end{array}$ & $\begin{array}{c}10 \\
(8,8)\end{array}$ & 0 & $\begin{array}{c}1 \\
(0,9)\end{array}$ & $\begin{array}{c}18 \\
(15,8)\end{array}$ & $\begin{array}{c}85 \\
(74,6)\end{array}$ & 0 \\
\hline $\begin{array}{l}\text { 8. O tempo que eu tive que } \\
\text { esperar para ser chamado(a) } \\
\text { para entrar na sala de coleta }\end{array}$ & $\begin{array}{c}9 \\
(7,9)\end{array}$ & 0 & $\begin{array}{c}3 \\
(2,6)\end{array}$ & $\begin{array}{c}39 \\
(34,2)\end{array}$ & $\begin{array}{c}63 \\
(55,3)\end{array}$ & 0 \\
\hline $\begin{array}{l}\text { 9. A gentileza do profissional que } \\
\text { coletou o meu sangue }\end{array}$ & $\begin{array}{c}10 \\
(8,8)\end{array}$ & $\begin{array}{c}1 \\
(0,9)\end{array}$ & $\begin{array}{c}1 \\
(0,9)\end{array}$ & $\begin{array}{c}14 \\
(12,3)\end{array}$ & $\begin{array}{c}88 \\
(77,2)\end{array}$ & 0 \\
\hline $\begin{array}{l}\text { 10. A segurança que o } \\
\text { Hemocentro me passa quanto ao } \\
\text { material usado para a coleta }\end{array}$ & $\begin{array}{c}10 \\
(8,8)\end{array}$ & 0 & 0 & $\begin{array}{c}18 \\
(15,8)\end{array}$ & $\begin{array}{c}66 \\
(75,4)\end{array}$ & 0 \\
\hline $\begin{array}{l}\text { 11. O cuidado que eu sinto estar } \\
\text { recebendo, durante a doação de } \\
\text { sangue }\end{array}$ & $\begin{array}{c}10 \\
(8,8)\end{array}$ & 0 & 0 & $\begin{array}{c}21 \\
(18,4)\end{array}$ & $\begin{array}{c}83 \\
(72,8)\end{array}$ & 0 \\
\hline 12. A higiene da sala de coleta & $\begin{array}{c}10 \\
(8,8)\end{array}$ & 0 & $\begin{array}{c}1 \\
(0,9)\end{array}$ & $\begin{array}{c}15 \\
(13,2)\end{array}$ & $\begin{array}{c}88 \\
(77,2)\end{array}$ & 0 \\
\hline $\begin{array}{l}\text { 13. A atenção que o profissional } \\
\text { que coleta o sangue tem naquilo } \\
\text { que está fazendo }\end{array}$ & $\begin{array}{c}10 \\
(8,8)\end{array}$ & 0 & 0 & $\begin{array}{c}14 \\
(12,4)\end{array}$ & $\begin{array}{c}89 \\
(78,8)\end{array}$ & 0 \\
\hline 14. O conforto da sala de coleta & $\begin{array}{c}10 \\
(8,8)\end{array}$ & 0 & 0 & $\begin{array}{c}19 \\
(16,7)\end{array}$ & $\begin{array}{c}85 \\
(74,6)\end{array}$ & 0 \\
\hline $\begin{array}{l}\text { 15. O tempo gasto durante a } \\
\text { doação de sangue, quando já } \\
\text { estava na sala de coleta }\end{array}$ & $\begin{array}{c}10 \\
(8,8)\end{array}$ & 0 & 0 & $\begin{array}{c}16 \\
(14,0)\end{array}$ & $\begin{array}{c}88 \\
(77,2)\end{array}$ & 0 \\
\hline $\begin{array}{l}\text { 16. A limpeza da copa (onde } \\
\text { servem o lanche) }\end{array}$ & $\begin{array}{c}9 \\
(7,9) \\
\end{array}$ & $\begin{array}{c}1 \\
(0,9) \\
\end{array}$ & 0 & $\begin{array}{c}20 \\
(17,5) \\
\end{array}$ & $\begin{array}{c}84 \\
(73,7) \\
\end{array}$ & 0 \\
\hline $\begin{array}{l}\text { 17. As explicações que os } \\
\text { profissionais me dão em relação } \\
\text { a tudo que eu quero entender }\end{array}$ & $\begin{array}{c}9 \\
(7,9)\end{array}$ & 0 & $\begin{array}{c}1 \\
(0,9)\end{array}$ & $\begin{array}{c}22 \\
(19,3)\end{array}$ & $\begin{array}{c}82 \\
(71,9)\end{array}$ & 0 \\
\hline $\begin{array}{l}\text { 18. O lanche que me ofereceram } \\
\text { depois da doação }\end{array}$ & $\begin{array}{c}9 \\
(7,9)\end{array}$ & $\begin{array}{c}1 \\
(0,9)\end{array}$ & $\begin{array}{c}2 \\
(1,8)\end{array}$ & $\begin{array}{c}27 \\
(23,7)\end{array}$ & $\begin{array}{c}75 \\
(65,8)\end{array}$ & 0 \\
\hline $\begin{array}{l}\text { 19. A quantidade de profissionais } \\
\text { disponíveis para me atender }\end{array}$ & $\begin{array}{c}10 \\
(8,8)\end{array}$ & 0 & 0 & $\begin{array}{c}22 \\
(19,3)\end{array}$ & $\begin{array}{c}82 \\
(71,9)\end{array}$ & 0 \\
\hline
\end{tabular}


Tabela 13. Pré-teste do instrumento, frequências de respostas aos itens relativos aos atributos da satisfação $(n=114)$. (continuação).

\begin{tabular}{|c|c|c|c|c|c|c|}
\hline & 赵 & 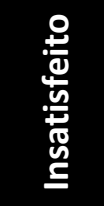 & 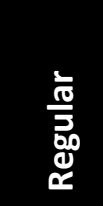 & 题 & 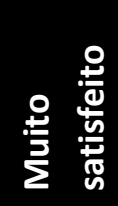 & 일 \\
\hline $\begin{array}{l}\text { 20. A competência profissional } \\
\text { das pessoas que trabalham no } \\
\text { Hemocentro }\end{array}$ & $\begin{array}{c}10 \\
(8,8)\end{array}$ & 0 & 0 & $\begin{array}{c}14 \\
(12,3)\end{array}$ & $\begin{array}{c}90 \\
(78,9)\end{array}$ & 0 \\
\hline $\begin{array}{l}\text { 21. } O \text { atendimento do } \\
\text { funcionário que trabalha na copa }\end{array}$ & $\begin{array}{c}9 \\
(7,9)\end{array}$ & $\begin{array}{c}1 \\
(0,9)\end{array}$ & $\begin{array}{c}4 \\
(3,5)\end{array}$ & $\begin{array}{c}30 \\
(26,3)\end{array}$ & $\begin{array}{c}70 \\
(61,4)\end{array}$ & 0 \\
\hline $\begin{array}{l}\text { 22. A disponibilidade dos } \\
\text { profissionais em me ouvir, em } \\
\text { qualquer momento }\end{array}$ & $\begin{array}{c}9 \\
(7,9)\end{array}$ & $\begin{array}{c}1 \\
(0,9)\end{array}$ & $\begin{array}{c}1 \\
(0,9)\end{array}$ & $\begin{array}{c}24 \\
(21,1)\end{array}$ & $\begin{array}{c}79 \\
(69,3)\end{array}$ & 0 \\
\hline $\begin{array}{l}\text { 23. Os horários de atendimento } \\
\text { do Hemocentro ao doador de } \\
\text { sangue }\end{array}$ & $\begin{array}{c}6 \\
(5,3)\end{array}$ & $\begin{array}{c}2 \\
(1,8)\end{array}$ & $\begin{array}{c}9 \\
(7,9)\end{array}$ & $\begin{array}{c}31 \\
(27,2)\end{array}$ & $\begin{array}{c}66 \\
(57,9)\end{array}$ & 0 \\
\hline $\begin{array}{l}\text { 24. O esforço dos profissionais } \\
\text { para eu me sentir à vontade }\end{array}$ & $\begin{array}{c}9 \\
(7,9)\end{array}$ & $\begin{array}{c}1 \\
(0,9)\end{array}$ & 0 & $\begin{array}{c}25 \\
(21,9)\end{array}$ & $\begin{array}{c}79 \\
(69,3)\end{array}$ & 0 \\
\hline $\begin{array}{l}\text { 25. O respeito com que as } \\
\text { pessoas me tratam no } \\
\text { Hemocentro }\end{array}$ & $\begin{array}{c}9 \\
(7,9)\end{array}$ & $\begin{array}{c}1 \\
(0,9)\end{array}$ & 0 & $\begin{array}{c}19 \\
(16,7)\end{array}$ & $\begin{array}{c}85 \\
(74,6)\end{array}$ & 0 \\
\hline
\end{tabular}

Cinco doadores responderam "muito insatisfeito" em todos os 25 itens do instrumento, e outros cinco doadores responderam predominantemente "muito insatisfeito" em quase todos os itens. Após o preenchimento do instrumento, estes doadores relataram não ter prestado atenção à escala e disseram que pensavam estar respondendo "muito satisfeito" enquanto indicavam "muito insatisfeito". Para evitar este problema na aplicação futura do instrumento, decidiu-se acrescentar emoticons à escala, representando as categorias de satisfação, como ilustrado na Figura 5. Os emoticons foram adicionados também à escala geral de satisfação. 


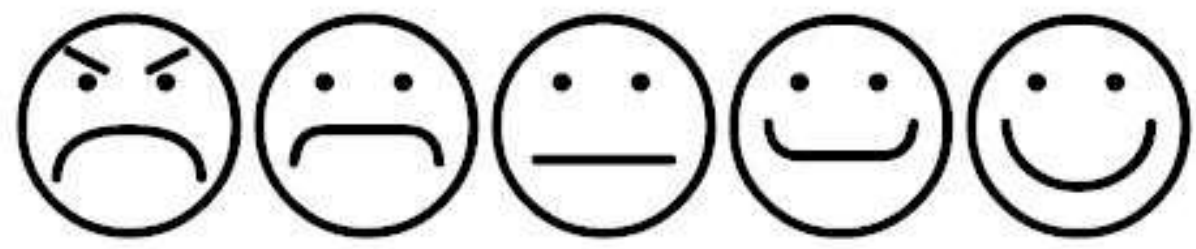

Figura 5. Emoticons usados para representar as categorias "muito insatisfeito", “insatisfeito", "regular", "satisfeito" e "muito satisfeito", respectivamente.

As Figuras 6 e 7 mostram a versão definitiva do instrumento de satisfação do doador de sangue, com a inserção dos emoticons e a retirada da coluna com o cabeçalho “não entendi”. 


\section{Questionário de Satisfação do Doador de Sangue}

Prezado(a) Doador(a),

Com o objetivo de oferecer um serviço de qualidade ao doador de sangue, pedimos sua colaboração em preencher esta pesquisa de satisfação. Sua participação é voluntária e confidencial. Você não deve escrever seu nome nesta folha, de forma que você não será identificado em nenhum momento.

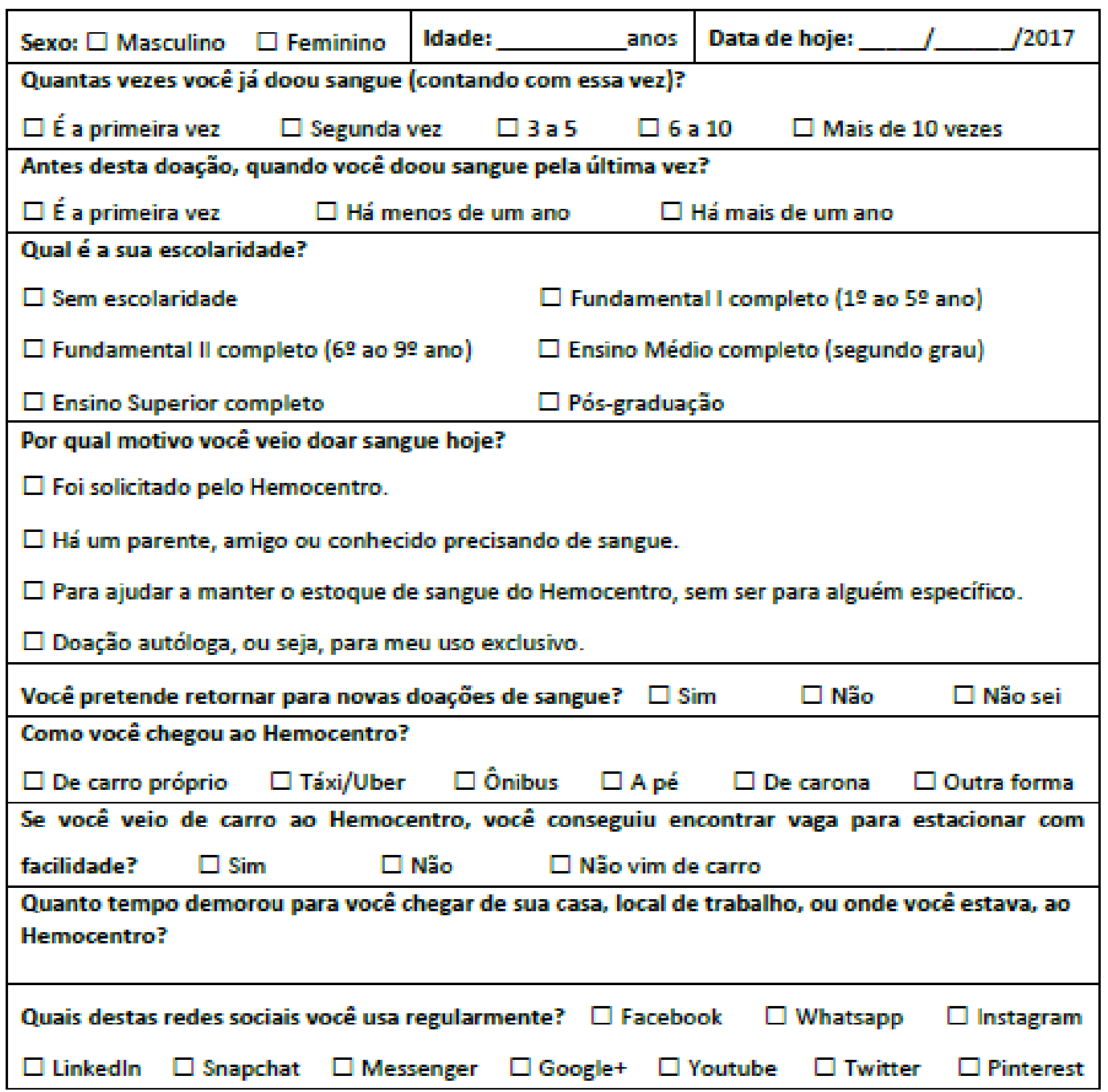

De uma maneira geral, o quanto você ficou satisfeito(a) com o serviço prestado pelo Hemocentro?

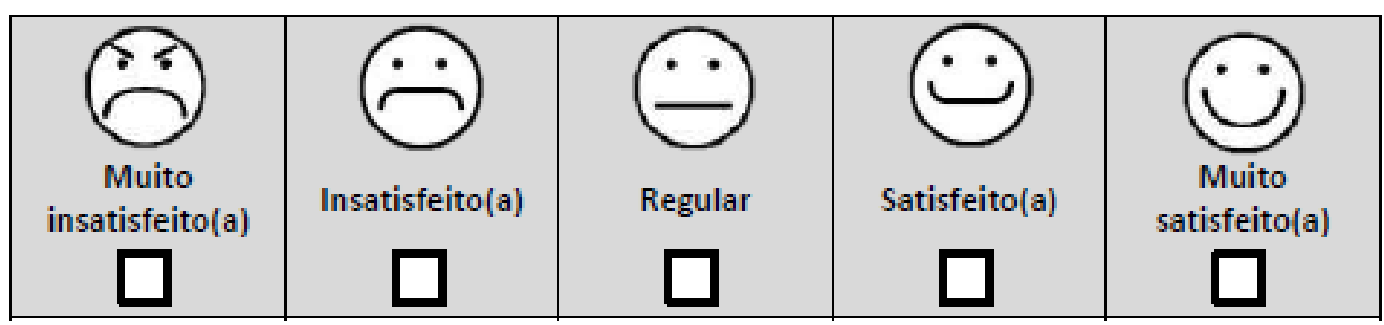

No verso desta folha, há alguns itens que podem estar relacionados à sua satisfação ou insatisfação quanto ao serviço que você recebeu HOJE no Hemocentro. Por favor, em cada item, marque com um " $\mathrm{X}$ " a resposta mais adequada à sua percepção de satisfação.

Figura 6. Versão final do instrumento de satisfação do doador de sangue (frente). 


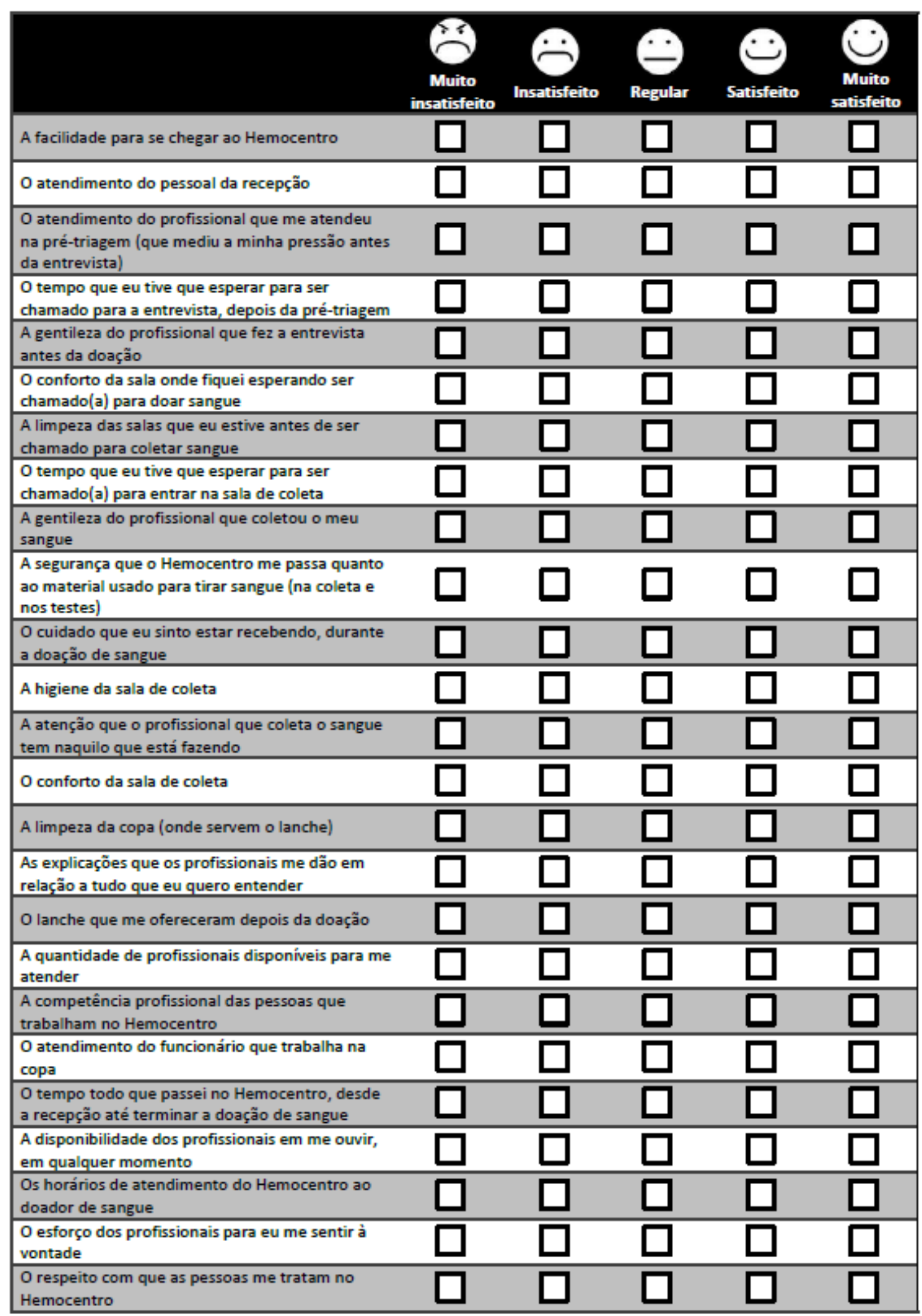

Agradecemos a sua participação!

Figura 7. Versão final do instrumento de satisfação do doador de sangue (verso). 


\subsection{Etapa 4: Validação do instrumento}

A Tabela 14 mostra o perfil dos $n=1.019$ doadores de sangue que participaram da etapa de validação do instrumento. A idade média dos doadores foi 33,5 anos, com um desvio padrão de 10,9 anos. A Tabela 15 mostra o tempo médio declarado para chegar ao Hemocentro, de acordo com o meio de transporte.

Tabela 14. Perfil dos doadores de sangue que participaram da etapa de validação do instrumento $(n=1.019)$.

\begin{tabular}{|c|c|c|c|}
\hline Variável & & $n$ & $\%$ \\
\hline \multirow{3}{*}{ Sexo } & Feminino & 443 & 43,6 \\
\hline & Masculino & 574 & 56,4 \\
\hline & Não respondeu & 2 & \\
\hline \multirow[t]{8}{*}{ Faixa etária } & 18 a 20 anos & 92 & 9,2 \\
\hline & 21 a 25 anos & 192 & 19,2 \\
\hline & 26 a 30 anos & 183 & 18,3 \\
\hline & 31 a 40 anos & 274 & 27,4 \\
\hline & 41 a 50 anos & 178 & 17,8 \\
\hline & 51 a 60 anos & 75 & 7,5 \\
\hline & Mais de 60 anos & 7 & 0,7 \\
\hline & Não respondeu & 18 & \\
\hline \multirow[t]{6}{*}{ Dia da doação } & Segunda-feira & 104 & 10,2 \\
\hline & Terça-feira & 125 & 12,3 \\
\hline & Quarta-feira & 80 & 7,9 \\
\hline & Quinta-feira & 160 & 15,7 \\
\hline & Sexta-feira & 228 & 22,4 \\
\hline & Sábado & 322 & 31,6 \\
\hline \multirow[t]{6}{*}{ Quantas vezes já doou sangue } & Primeira vez & 192 & 19,2 \\
\hline & Segunda vez & 113 & 11,3 \\
\hline & 3 a 5 & 254 & 25,4 \\
\hline & 6 a 10 & 161 & 16,1 \\
\hline & Mais de 10 & 278 & 27,9 \\
\hline & Não respondeu & 21 & \\
\hline \multirow[t]{4}{*}{ Quando doou sangue pela última vez } & Primeira vez & 183 & 18,7 \\
\hline & Há menos de um ano & 546 & 55,8 \\
\hline & Há mais de um ano & 250 & 25,5 \\
\hline & Não respondeu & 40 & \\
\hline
\end{tabular}


Tabela 14. Perfil dos doadores de sangue que participaram da etapa de validação do instrumento $(n=1.019)$. (continuação).

\begin{tabular}{|c|c|c|c|}
\hline Variável & & $n$ & $\%$ \\
\hline \multirow[t]{7}{*}{ Escolaridade } & Sem escolaridade & 2 & 0,2 \\
\hline & Fundamental I completo & 38 & 3,7 \\
\hline & Fundamental II completo & 90 & 8,8 \\
\hline & Ensino médio & 539 & 53,0 \\
\hline & Superior & 253 & 24,9 \\
\hline & Pós-graduação & 95 & 9,3 \\
\hline & Não respondeu & 2 & \\
\hline \multirow[t]{5}{*}{ Motivo da doação } & Solicitação do Hemocentro & 29 & 2,9 \\
\hline & Para um familiar ou amigo & 70 & 6,9 \\
\hline & Manter o estoque & 902 & 89,0 \\
\hline & Doação autóloga & 12 & 1,2 \\
\hline & Não respondeu & 6 & \\
\hline \multirow[t]{7}{*}{ Como chegou ao Hemocentro } & De carro próprio & 707 & 69,9 \\
\hline & Táxi/Uber & 7 & 0,7 \\
\hline & Ônibus & 57 & 5,6 \\
\hline & A pé & 53 & 5,2 \\
\hline & De carona & 80 & 7,9 \\
\hline & Outra forma & 107 & 10,6 \\
\hline & Não respondeu & 8 & \\
\hline \multirow[t]{4}{*}{ Facilidade para encontrar vaga para estacionar } & Sim & 570 & 58,3 \\
\hline & Não & 209 & 21,4 \\
\hline & Não veio de carro & 198 & 20,3 \\
\hline & Não respondeu & 42 & \\
\hline \multirow[t]{6}{*}{ Uso de redes sociais } & Facebook & 774 & 76,0 \\
\hline & Whatsapp & 920 & 90,5 \\
\hline & Instagram & 362 & 35,5 \\
\hline & Messenger & 141 & 13,8 \\
\hline & Google+ & 12 & 1,2 \\
\hline & Youtube & 253 & 24,8 \\
\hline
\end{tabular}

Tabela 15. Tempo médio para chegar ao Hemocentro $(n=1.019)$.

\begin{tabular}{|c|c|c|c|c|c|c|}
\hline \multirow[b]{2}{*}{ Como chegou ao Hemocentro } & \multirow[b]{2}{*}{ Total } & \multicolumn{5}{|c|}{ Tempo para chegar ao Hemocentro (minutos) } \\
\hline & & Respostas & Média & $\begin{array}{l}\text { Desvio } \\
\text { padrão }\end{array}$ & Mínimo & Máximo \\
\hline De carro próprio & 707 & 651 & 17,7 & 12,9 & 2 & 90 \\
\hline Táxi/Uber & 7 & 3 & 11,7 & 2,9 & 10 & 15 \\
\hline Ônibus & 57 & 47 & 50,0 & 22,2 & 10 & 120 \\
\hline A pé & 53 & 45 & 23,5 & 17,9 & 5 & 90 \\
\hline De carona & 80 & 73 & 16,5 & 11,8 & 1 & 70 \\
\hline Outra forma & 107 & 95 & 18,8 & 15,5 & 5 & 80 \\
\hline
\end{tabular}


A Tabela 16 mostra as frequências de respostas à pergunta sobre a satisfação geral e aos 25 itens que compõem o questionário de satisfação do doador de sangue.

Tabela 16. Frequências de respostas aos itens relativos aos atributos da satisfação, considerando a etapa de validação do instrumento $(n=1.019)$.

\begin{tabular}{|c|c|c|c|c|c|c|}
\hline & 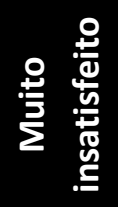 & 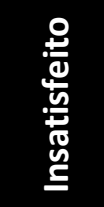 & 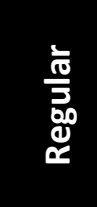 & 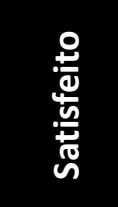 & $\stackrel{\circ}{\frac{8}{2}}$ & 월 \\
\hline Satisfação geral & $\begin{array}{c}16 \\
(1,6)\end{array}$ & $\begin{array}{c}1 \\
(0,1)\end{array}$ & $\begin{array}{c}10 \\
(1,0)\end{array}$ & $\begin{array}{c}158 \\
(15,6)\end{array}$ & $\begin{array}{c}831 \\
(81,8)\end{array}$ & 3 \\
\hline $\begin{array}{l}\text { 1. A facilidade para se chegar ao } \\
\text { Hemocentro }\end{array}$ & $\begin{array}{c}12 \\
(1,2)\end{array}$ & $\begin{array}{c}5 \\
(0,5)\end{array}$ & $\begin{array}{c}50 \\
(4,9)\end{array}$ & $\begin{array}{c}450 \\
(44,4)\end{array}$ & $\begin{array}{c}497 \\
(49,0)\end{array}$ & 5 \\
\hline $\begin{array}{l}\text { 2. O atendimento do pessoal da } \\
\text { recepção }\end{array}$ & $\begin{array}{c}14 \\
(1,4)\end{array}$ & $\begin{array}{c}6 \\
(0,6)\end{array}$ & $\begin{array}{c}29 \\
(2,9)\end{array}$ & $\begin{array}{c}254 \\
(25,3)\end{array}$ & $\begin{array}{c}702 \\
(69,9)\end{array}$ & 14 \\
\hline $\begin{array}{l}\text { 3. A gentileza do profissional que } \\
\text { fez a entrevista antes da doação }\end{array}$ & $\begin{array}{c}14 \\
(1,4)\end{array}$ & $\begin{array}{c}2 \\
(0,2)\end{array}$ & $\begin{array}{c}8 \\
(0,8)\end{array}$ & $\begin{array}{c}222 \\
(22,1)\end{array}$ & $\begin{array}{c}761 \\
(75,6)\end{array}$ & 12 \\
\hline $\begin{array}{l}\text { 4. O tempo gasto durante a } \\
\text { entrevista, antes da doação de } \\
\text { sangue }\end{array}$ & $\begin{array}{c}16 \\
(1,6)\end{array}$ & $\begin{array}{c}8 \\
(0,8)\end{array}$ & $\begin{array}{c}68 \\
(6,7)\end{array}$ & $\begin{array}{c}333 \\
(32,9)\end{array}$ & $\begin{array}{c}587 \\
(58,0)\end{array}$ & 7 \\
\hline $\begin{array}{l}\text { 5. } O \text { atendimento do profissional } \\
\text { que mediu a minha pressão antes } \\
\text { da entrevista }\end{array}$ & $\begin{array}{c}13 \\
(1,3)\end{array}$ & $\begin{array}{c}3 \\
(0,3)\end{array}$ & $\begin{array}{c}15 \\
(1,5)\end{array}$ & $\begin{array}{c}246 \\
(24,3)\end{array}$ & $\begin{array}{c}736 \\
(72,7)\end{array}$ & 6 \\
\hline $\begin{array}{l}\text { 6. O conforto da sala onde fiquei } \\
\text { esperando ser chamado(a) para } \\
\text { doar sangue }\end{array}$ & $\begin{array}{c}13 \\
(1,3)\end{array}$ & $\begin{array}{c}2 \\
(0,2)\end{array}$ & $\begin{array}{c}11 \\
(1,1)\end{array}$ & $\begin{array}{c}310 \\
(30,5)\end{array}$ & $\begin{array}{c}679 \\
(66,9)\end{array}$ & 4 \\
\hline $\begin{array}{l}\text { 7. A limpeza das salas que eu } \\
\text { estive antes de ser chamado para } \\
\text { coletar sangue }\end{array}$ & $\begin{array}{c}13 \\
(1,3)\end{array}$ & $\begin{array}{c}2 \\
(0,2)\end{array}$ & $\begin{array}{c}3 \\
(0,3)\end{array}$ & $\begin{array}{c}202 \\
(20,0)\end{array}$ & $\begin{array}{c}791 \\
(78,2)\end{array}$ & 8 \\
\hline $\begin{array}{l}\text { 8. O tempo que eu tive que } \\
\text { esperar para ser chamado(a) } \\
\text { para entrar na sala de coleta }\end{array}$ & $\begin{array}{c}14 \\
(1,4)\end{array}$ & $\begin{array}{c}10 \\
(1,0)\end{array}$ & $\begin{array}{c}70 \\
(6,9)\end{array}$ & $\begin{array}{c}301 \\
(29,7)\end{array}$ & $\begin{array}{c}617 \\
(61,0)\end{array}$ & 7 \\
\hline $\begin{array}{l}\text { 9. A gentileza do profissional que } \\
\text { coletou o meu sangue }\end{array}$ & $\begin{array}{c}14 \\
(1,4)\end{array}$ & $\begin{array}{c}2 \\
(0,2)\end{array}$ & $\begin{array}{c}2 \\
(0,2)\end{array}$ & $\begin{array}{c}155 \\
(15,3)\end{array}$ & $\begin{array}{c}840 \\
(82,9)\end{array}$ & 6 \\
\hline $\begin{array}{l}\text { 10. A segurança que o } \\
\text { Hemocentro me passa quanto ao } \\
\text { material usado para a coleta }\end{array}$ & $\begin{array}{c}13 \\
(1,3)\end{array}$ & $\begin{array}{c}1 \\
(0,1)\end{array}$ & $\begin{array}{c}2 \\
(0,2)\end{array}$ & $\begin{array}{c}180 \\
(17,8)\end{array}$ & $\begin{array}{c}817 \\
(80,7)\end{array}$ & 6 \\
\hline $\begin{array}{l}\text { 11. O cuidado que eu sinto estar } \\
\text { recebendo, durante a doação de } \\
\text { sangue }\end{array}$ & $\begin{array}{c}13 \\
(1,3)\end{array}$ & $\begin{array}{c}1 \\
(0,1)\end{array}$ & $\begin{array}{c}1 \\
(0,1)\end{array}$ & $\begin{array}{c}167 \\
(16,5)\end{array}$ & $\begin{array}{c}830 \\
(82,0)\end{array}$ & 7 \\
\hline
\end{tabular}


Tabela 16. Frequências de respostas aos itens relativos aos atributos da satisfação, considerando a etapa de validação do instrumento $(n=1.019)$.

\begin{tabular}{|c|c|c|c|c|c|c|}
\hline & 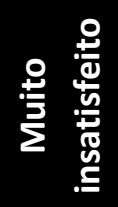 & 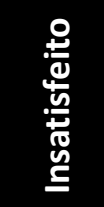 & 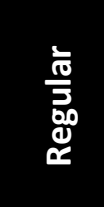 & 赵 & 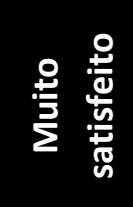 & 일 \\
\hline 12. A higiene da sala de coleta & $\begin{array}{c}13 \\
(1,3)\end{array}$ & $\begin{array}{c}1 \\
(0,1)\end{array}$ & 0 & $\begin{array}{c}147 \\
(14,5)\end{array}$ & $\begin{array}{c}850 \\
(84,1)\end{array}$ & 8 \\
\hline $\begin{array}{l}\text { 13. A atenção que o profissional } \\
\text { que coleta o sangue tem naquilo } \\
\text { que está fazendo }\end{array}$ & $\begin{array}{c}13 \\
(1,3)\end{array}$ & $\begin{array}{c}2 \\
(0,2)\end{array}$ & $\begin{array}{c}2 \\
(0,2)\end{array}$ & $\begin{array}{c}155 \\
(15,3)\end{array}$ & $\begin{array}{c}841 \\
(83,0)\end{array}$ & 6 \\
\hline 14. O conforto da sala de coleta & $\begin{array}{c}13 \\
(1,3)\end{array}$ & $\begin{array}{c}1 \\
(0,1)\end{array}$ & $\begin{array}{c}4 \\
(0,4)\end{array}$ & $\begin{array}{c}213 \\
(21,0)\end{array}$ & $\begin{array}{c}783 \\
(77,2)\end{array}$ & 5 \\
\hline $\begin{array}{l}\text { 15. O tempo gasto durante a } \\
\text { doação de sangue, quando já } \\
\text { estava na sala de coleta }\end{array}$ & $\begin{array}{c}13 \\
(1,3)\end{array}$ & $\begin{array}{c}1 \\
(0,1)\end{array}$ & $\begin{array}{c}3 \\
(0,3)\end{array}$ & $\begin{array}{c}169 \\
(16,7)\end{array}$ & $\begin{array}{c}827 \\
(81,6)\end{array}$ & 6 \\
\hline $\begin{array}{l}\text { 16. A limpeza da copa (onde } \\
\text { servem o lanche) }\end{array}$ & $\begin{array}{c}13 \\
(1,3)\end{array}$ & $\begin{array}{c}1 \\
(0,1)\end{array}$ & $\begin{array}{c}6 \\
(0,6) \\
\end{array}$ & $\begin{array}{c}181 \\
(17,9)\end{array}$ & $\begin{array}{c}812 \\
(80,2)\end{array}$ & 6 \\
\hline $\begin{array}{l}\text { 17. As explicações que os } \\
\text { profissionais me dão em relação } \\
\text { a tudo que eu quero entender }\end{array}$ & $\begin{array}{c}14 \\
(1,4)\end{array}$ & $\begin{array}{c}2 \\
(0,2)\end{array}$ & $\begin{array}{c}11 \\
(1,1)\end{array}$ & $\begin{array}{c}204 \\
(20,1)\end{array}$ & $\begin{array}{c}782 \\
(77,2)\end{array}$ & 6 \\
\hline $\begin{array}{l}\text { 18. O lanche que me ofereceram } \\
\text { depois da doação }\end{array}$ & $\begin{array}{c}14 \\
(1,4)\end{array}$ & $\begin{array}{c}8 \\
(0,8)\end{array}$ & $\begin{array}{c}30 \\
(3,0)\end{array}$ & $\begin{array}{c}271 \\
(26,7)\end{array}$ & $\begin{array}{c}692 \\
(68,2)\end{array}$ & 4 \\
\hline $\begin{array}{l}\text { 19. A quantidade de profissionais } \\
\text { disponíveis para me atender }\end{array}$ & $\begin{array}{c}13 \\
(1,3)\end{array}$ & $\begin{array}{c}1 \\
(0,1)\end{array}$ & $\begin{array}{c}3 \\
(0,3)\end{array}$ & $\begin{array}{c}194 \\
(19,2)\end{array}$ & $\begin{array}{c}801 \\
(79,2)\end{array}$ & 7 \\
\hline $\begin{array}{l}\text { 20. A competência profissional } \\
\text { das pessoas que trabalham no } \\
\text { Hemocentro }\end{array}$ & $\begin{array}{c}13 \\
(1,3)\end{array}$ & $\begin{array}{c}3 \\
(0,3)\end{array}$ & $\begin{array}{c}11 \\
(1,1)\end{array}$ & $\begin{array}{c}184 \\
(18,2)\end{array}$ & $\begin{array}{c}797 \\
(79,1)\end{array}$ & 11 \\
\hline $\begin{array}{l}\text { 21. O atendimento do } \\
\text { funcionário que trabalha na copa }\end{array}$ & $\begin{array}{c}16 \\
(1,6)\end{array}$ & $\begin{array}{c}9 \\
(0,9)\end{array}$ & $\begin{array}{c}43 \\
(4,2)\end{array}$ & $\begin{array}{c}282 \\
(27,8)\end{array}$ & $\begin{array}{c}664 \\
(65,5) \\
\end{array}$ & 5 \\
\hline $\begin{array}{l}\text { 22. A disponibilidade dos } \\
\text { profissionais em me ouvir, em } \\
\text { qualquer momento }\end{array}$ & $\begin{array}{c}13 \\
(1,3)\end{array}$ & $\begin{array}{c}1 \\
(0,1)\end{array}$ & $\begin{array}{c}9 \\
(0,9)\end{array}$ & $\begin{array}{c}239 \\
(23,6)\end{array}$ & $\begin{array}{c}749 \\
(74,1)\end{array}$ & 8 \\
\hline $\begin{array}{l}\text { 23. Os horários de atendimento } \\
\text { do Hemocentro ao doador de } \\
\text { sangue }\end{array}$ & $\begin{array}{c}14 \\
(1,4)\end{array}$ & $\begin{array}{c}7 \\
(0,7)\end{array}$ & $\begin{array}{c}52 \\
(5,1)\end{array}$ & $\begin{array}{c}304 \\
(30,0)\end{array}$ & $\begin{array}{c}637 \\
(62,8)\end{array}$ & 5 \\
\hline $\begin{array}{l}\text { 24. O esforço dos profissionais } \\
\text { para eu me sentir à vontade }\end{array}$ & $\begin{array}{c}13 \\
(1,3)\end{array}$ & $\begin{array}{c}1 \\
(0,1)\end{array}$ & $\begin{array}{c}4 \\
(0,4) \\
\end{array}$ & $\begin{array}{c}213 \\
(21,0)\end{array}$ & $\begin{array}{c}783 \\
(77,2) \\
\end{array}$ & 5 \\
\hline $\begin{array}{l}\text { 25. O respeito com que as } \\
\text { pessoas me tratam no } \\
\text { Hemocentro }\end{array}$ & $\begin{array}{c}13 \\
(1,3)\end{array}$ & $\begin{array}{c}1 \\
(0,1)\end{array}$ & $\begin{array}{c}3 \\
(0,3)\end{array}$ & $\begin{array}{c}180 \\
(17,8)\end{array}$ & $\begin{array}{c}815 \\
(80,5)\end{array}$ & 7 \\
\hline
\end{tabular}


A Figura 8 mostra as correlações policóricas entre a satisfação geral e os 25 itens que compõem o instrumento de satisfação, considerando a amostra de 1.019 doadores de sangue. Os números mostrados na figura referem-se aos números dos itens, como descrito na Tabela 16.

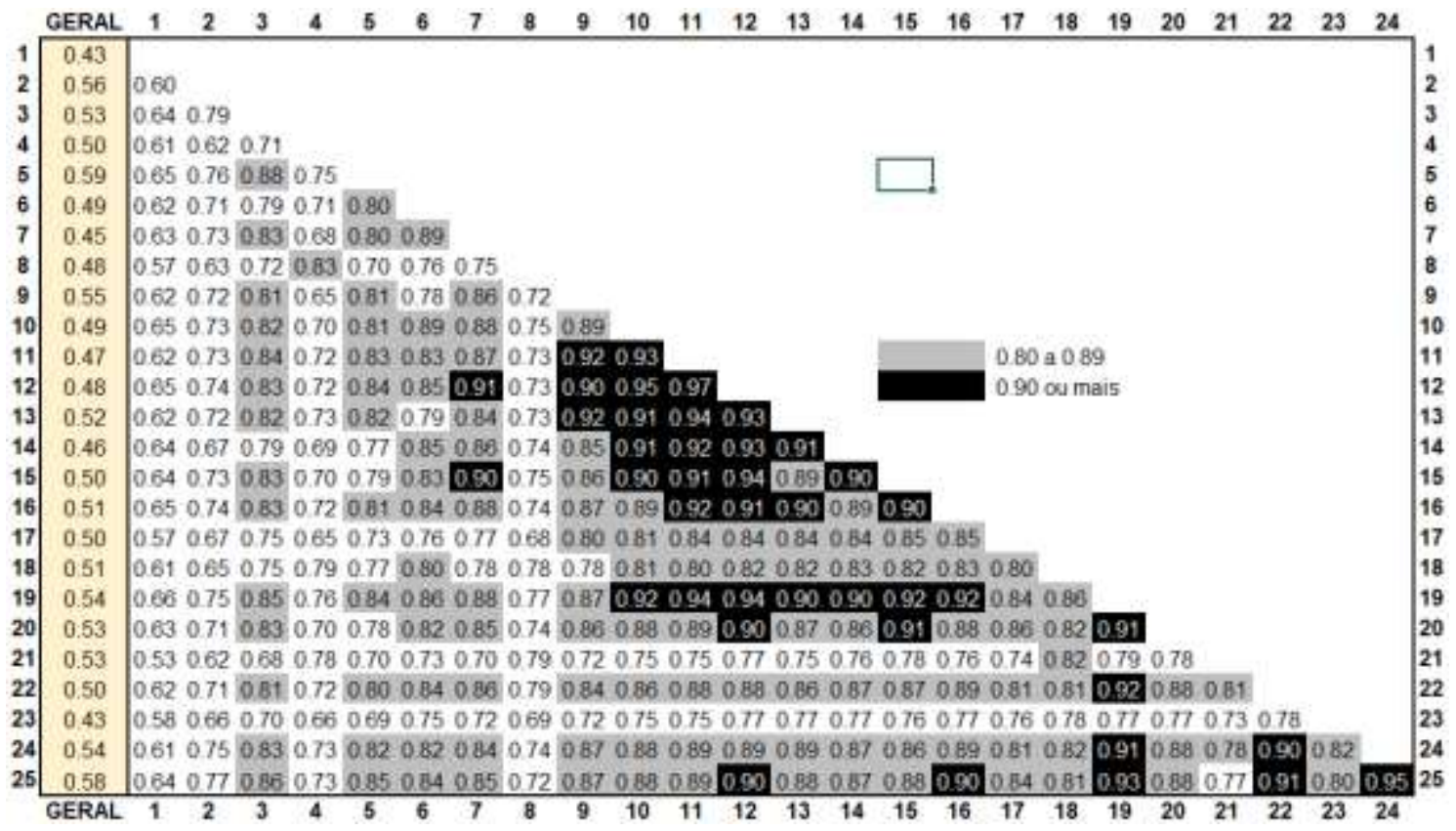

Figura 8. Matriz de correlações policóricas entre os itens do questionário de satisfação do doador de sangue $(n=1.019)$.

O item 1, "facilidade para se chegar ao Hemocentro", apresentou correlações relativamente baixas com os demais itens (menores ou iguais a 0,66). Esta matriz de correções policóricas foi utilizada para a análise de consistência interna do questionário e para a análise fatorial exploratória.

\section{Consistência interna do questionário}

A consistência interna do questionário, quanto aos 25 itens que pretendem avaliar a satisfação do doador foi medida pelo coeficiente alfa de Cronbach (BLAND E 
ALTMAN, 1997). Um coeficiente de 0,985 indicou uma consistência interna muito alta, ou seja, os 25 itens formam um conjunto consistente no sentido de mensurar um mesmo objeto, que pretende ser a satisfação do doador. A Tabela 17 mostra as correlações entre cada item e o total (ou seja, os 25 itens tomados como um "conjunto") e os valores que seriam obtidos para o coeficiente alfa de Cronbach caso cada item fosse desprezado do instrumento.

Tabela 17. Análise de consistência interna do instrumento $(n=1.019)$.

\begin{tabular}{ccc}
\hline Item & $\begin{array}{c}\text { Correlação entre o } \\
\text { item e o total }\end{array}$ & $\begin{array}{c}\text { Coeficiente alfa de Cronbach, } \\
\text { se o item é desprezado }\end{array}$ \\
\hline $\mathbf{1}$ & 0,6386 & 0,9859 \\
$\mathbf{2}$ & 0,7451 & 0,9853 \\
$\mathbf{3}$ & 0,8552 & 0,9847 \\
$\mathbf{4}$ & 0,7291 & 0,9854 \\
$\mathbf{5}$ & 0,8416 & 0,9848 \\
$\mathbf{6}$ & 0,8526 & 0,9847 \\
$\mathbf{7}$ & 0,8858 & 0,9845 \\
$\mathbf{8}$ & 0,7533 & 0,9852 \\
$\mathbf{9}$ & 0,8825 & 0,9845 \\
$\mathbf{1 0}$ & 0,9026 & 0,9844 \\
$\mathbf{1 1}$ & 0,9116 & 0,9844 \\
$\mathbf{1 2}$ & 0,9148 & 0,9844 \\
$\mathbf{1 3}$ & 0,9048 & 0,9844 \\
$\mathbf{1 4}$ & 0,8966 & 0,9845 \\
$\mathbf{1 5}$ & 0,9023 & 0,9844 \\
$\mathbf{1 6}$ & 0,9031 & 0,9844 \\
$\mathbf{1 7}$ & 0,8351 & 0,9848 \\
$\mathbf{1 8}$ & 0,8194 & 0,9849 \\
$\mathbf{1 9}$ & 0,9200 & 0,9843 \\
$\mathbf{2 0}$ & 0,8857 & 0,9845 \\
$\mathbf{2 1}$ & 0,7578 & 0,9852 \\
$\mathbf{2 2}$ & 0,8927 & 0,9845 \\
$\mathbf{2 3}$ & 0,7491 & 0,9853 \\
$\mathbf{2 4}$ & 0,9075 & 0,9844 \\
$\mathbf{2 5}$ & 0,9076 & 0,9844 \\
\hline
\end{tabular}


A última coluna da Tabela 17 sugere que a retirada de qualquer item do instrumento não traz alterações importantes para a consistência interna do questionário. O item 1, "facilidade para se chegar ao Hemocentro", foi o que apresentou menor correlação com o total $(0,6386)$.

\section{Análise fatorial exploratória}

Uma análise fatorial exploratória para os 25 itens que compõem o instrumento de satisfação, considerando a matriz de correlações apresentada na Figura 8, apresenta os autovalores descritos na Figura 9 (scree plot), considerando um a oito fatores (após rotação tipo varimax).

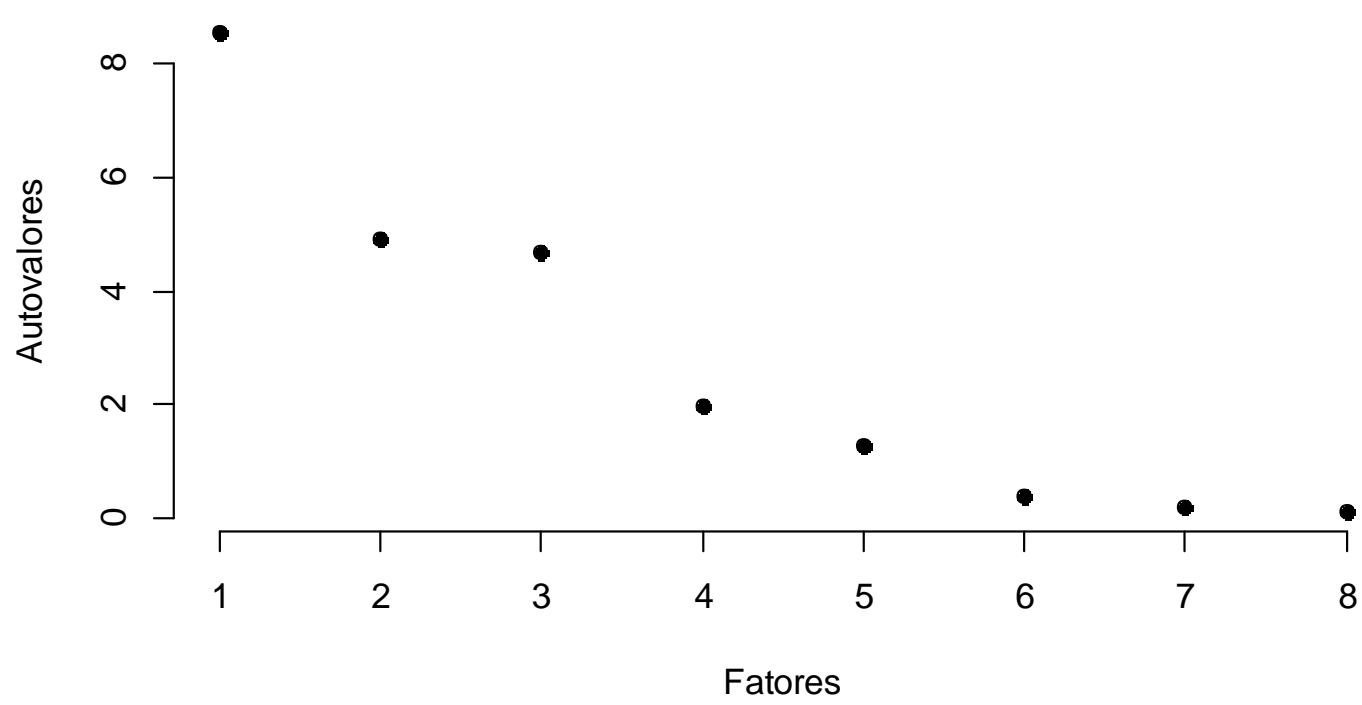

Figura 9. Scree plot, mostrado os autovalores encontrados em uma análise fatorial exploratória para os 25 itens que compõem o instrumento de satisfação.

A Tabela 18 mostra as cargas fatoriais, considerando quatro fatores (aqueles com autovalores maiores que 1). No corpo da tabela, são destacadas as cargas fatoriais que parecem ser mais representativas em cada fator (arbitrariamente, foram destacadas 
aquelas maiores que 0,5$)$. Neste caso, não se observa uma clara estrutura fatorial do instrumento, considerando que a solução encontrada não coincide com a composição dos domínios pretendidos ao instrumento (acessibilidade/conveniência, aspectos técnicos e aspectos interpessoais).

Tabela 18. Cargas fatoriais, após rotação tipo varimax $(n=1.019)$.

\begin{tabular}{ccccc}
\hline Item & Fator1 & Fator2 & Fator3 & Fator4 \\
\hline $\mathbf{1}$ & 0,34477 & 0,33685 & 0,46015 & 0,19837 \\
$\mathbf{2}$ & 0,37683 & 0,28554 & 0,63441 & 0,25131 \\
$\mathbf{3}$ & 0,47122 & 0,35827 & 0,67768 & 0,17328 \\
$\mathbf{4}$ & 0,29439 & 0,79017 & 0,38866 & 0,13168 \\
$\mathbf{5}$ & 0,45825 & 0,41345 & 0,65295 & 0,15084 \\
$\mathbf{6}$ & 0,48626 & 0,40354 & 0,42200 & 0,26398 \\
$\mathbf{7}$ & 0,59577 & 0,34193 & 0,46423 & 0,15891 \\
$\mathbf{8}$ & 0,34871 & 0,72942 & 0,29739 & 0,17044 \\
$\mathbf{9}$ & 0,71959 & 0,32333 & 0,43984 & 0,20354 \\
$\mathbf{1 0}$ & 0,70355 & 0,36538 & 0,40688 & 0,20642 \\
$\mathbf{1 1}$ & 0,78086 & 0,36850 & 0,40622 & 0,16924 \\
$\mathbf{1 2}$ & 0,75404 & 0,36368 & 0,41006 & 0,19945 \\
$\mathbf{1 3}$ & 0,75617 & 0,39340 & 0,39303 & 0,24687 \\
$\mathbf{1 4}$ & 0,72368 & 0,38995 & 0,29266 & 0,28661 \\
$\mathbf{1 5}$ & 0,68842 & 0,38469 & 0,39316 & 0,24343 \\
$\mathbf{1 6}$ & 0,65958 & 0,38294 & 0,42398 & 0,27680 \\
$\mathbf{1 7}$ & 0,62515 & 0,35882 & 0,32777 & 0,39440 \\
$\mathbf{1 8}$ & 0,49511 & 0,58720 & 0,30872 & 0,33516 \\
$\mathbf{1 9}$ & 0,65513 & 0,43051 & 0,42855 & 0,24224 \\
$\mathbf{2 0}$ & 0,64673 & 0,38786 & 0,38961 & 0,30861 \\
$\mathbf{2 1}$ & 0,43705 & 0,65633 & 0,22575 & 0,29984 \\
$\mathbf{2 2}$ & 0,57598 & 0,45142 & 0,36321 & 0,30502 \\
$\mathbf{2 3}$ & 0,42518 & 0,41178 & 0,32233 & 0,56729 \\
$\mathbf{2 4}$ & 0,58937 & 0,38590 & 0,43837 & 0,40585 \\
$\mathbf{2 5}$ & 0,57756 & 0,35621 & 0,49898 & 0,36069 \\
\hline & & & & \\
\hline
\end{tabular}


Floor effect e ceiling effect

Observou-se que 10 participantes $(1,1 \%)$ responderam "muito insatisfeito" a todos os 25 itens do instrumento (floor effect, ou "efeito chão"). Destes, seis responderam "muito satisfeito" à questão de satisfação geral, sugerindo algum mal entendimento do instrumento. Por outro lado, 293 (31,2\%) responderam "muito satisfeito" a todos os itens (ceiling effect, ou "efeito teto"). Dentre estes, $274(93,8 \%)$ também responderam "muito satisfeito" à questão de satisfação geral. 


\subsection{Interpretação do instrumento}

\section{Top box analysis}

Na Tabela 16, observou-se que 81,8\% dos 1.019 participantes que compuseram a Etapa 4 declararam estar "totalmente satisfeitos" quando indagados sobre a satisfação geral. A Tabela 19 apresenta uma top box analysis, ou seja, uma análise da associação entre as variáveis que caracterizam os doadores de sangue e as frequências de participantes que declararam estar, em geral, "totalmente satisfeitos".

Tabela 19. Top box analysis, satisfação geral $(n=1.019)$.

\begin{tabular}{|c|c|c|c|c|c|}
\hline \multirow{2}{*}{ Variável } & & \multirow[b]{2}{*}{ Total } & \multicolumn{2}{|c|}{ Top box } & \multirow{2}{*}{$\begin{array}{r}\text { Razões } \\
(\text { IC 95\%) }\end{array}$} \\
\hline & & & $n$ & $\%$ & \\
\hline \multirow[t]{2}{*}{ Sexo } & Feminino & 443 & 362 & 81,7 & Referência \\
\hline & Masculino & 571 & 468 & 82,0 & $1,0(0,9-1,1)$ \\
\hline \multirow[t]{7}{*}{ Idade } & 18 a 20 anos & 92 & 80 & 87,0 & Referência \\
\hline & 21 a 25 anos & 192 & 159 & 82,8 & $0,9(0,8-1,1)$ \\
\hline & 26 a 30 anos & 182 & 146 & 80,2 & $0,9(0,8-1,0)$ \\
\hline & 31 a 40 anos & 274 & 228 & 83,2 & $0,9(0,8-1,0)$ \\
\hline & 41 a 50 anos & 176 & 146 & 83,0 & $0,9(0,8-1,1)$ \\
\hline & 51 a 60 anos & 75 & 53 & 70,7 & $0,8(0,6-0,9)^{*}$ \\
\hline & Mais de 60 anos & 7 & 5 & 71,4 & $0,8(0,5-1,3)$ \\
\hline \multirow[t]{6}{*}{ Dia da doação } & Sexta-feira & 227 & 177 & 78,0 & Referência \\
\hline & Sábado & 321 & 270 & 84,1 & $1,1(0,9-1,2)$ \\
\hline & Segunda-feira & 104 & 87 & 83,7 & $1,0(0,9-1,2)$ \\
\hline & Terça-feira & 125 & 102 & 81,6 & $1,1(0,9-1,2)$ \\
\hline & Quarta-feira & 80 & 69 & 86,3 & $1,0(0,9-1,1)$ \\
\hline & Quinta-feira & 159 & 126 & 79,3 & $1,1(0,9-1,2)$ \\
\hline \multirow{5}{*}{$\begin{array}{l}\text { Quantas vezes já } \\
\text { doou sangue }\end{array}$} & Primeira vez & 192 & 161 & 83,8 & Referência \\
\hline & Segunda vez & 112 & 87 & 77,7 & $0,9(0,8-1,0)$ \\
\hline & 3 a 5 & 254 & 205 & 80,7 & $0,9(0,8-1,0)$ \\
\hline & 6 a 10 & 159 & 135 & 84,9 & $1,0(0,9-1,1)$ \\
\hline & Mais de 10 & 278 & 226 & 81,3 & $1,0(0,8-1,1)$ \\
\hline Quando doou sangue & Primeira vez & 183 & 151 & 82,5 & Referência \\
\hline \multirow{2}{*}{ Pela última vez } & Há menos de um ano & 545 & 446 & 81,8 & $1,0(0,9-1,1)$ \\
\hline & Há mais de um ano & 248 & 200 & 80,7 & $0,9(0,8-1,1)$ \\
\hline
\end{tabular}


Tabela 19. Top box analysis, satisfação geral ( $n=1.019)$. (continuação).

\begin{tabular}{|c|c|c|c|c|c|}
\hline \multirow{2}{*}{ Variáveis } & & \multirow[b]{2}{*}{ Total } & \multicolumn{2}{|c|}{ Top box } & \multirow{2}{*}{$\begin{array}{r}\text { Razões } \\
(\text { IC 95\%) (a) } \\
\end{array}$} \\
\hline & & & $n$ & $\%$ & \\
\hline \multirow{6}{*}{ Escolaridade } & Sem escolaridade & 2 & 1 & 50,0 & Referência \\
\hline & Fundamental I completo & 38 & 27 & 71,1 & \\
\hline & Fundamental II completo & 90 & 68 & 75,6 & $1,1(0,8-1,4)$ \\
\hline & Ensino médio & 536 & 440 & 82,1 & $1,2(0,9-1,4)$ \\
\hline & Superior & 253 & 209 & 82,6 & $1,2(0,9-1,5)$ \\
\hline & Pós-graduação & 95 & 84 & 88,4 & $1,3(1,0-1,6)$ \\
\hline \multirow[t]{4}{*}{ Motivo da doação } & $\begin{array}{l}\text { Solicitação do } \\
\text { Hemocentro }\end{array}$ & 29 & 25 & 86,2 & Referência \\
\hline & Para um familiar ou amigo & 70 & 49 & 70,0 & $0,8(0,6-1,0)$ \\
\hline & Manter o estoque & 899 & 743 & 82,7 & $0,9(0,8-1,1)$ \\
\hline & Doação autóloga & 12 & 11 & 91,7 & $1,1(0,8-1,3)$ \\
\hline \multirow{6}{*}{$\begin{array}{l}\text { Como chegou ao } \\
\text { Hemocentro }\end{array}$} & Ônibus & 57 & 38 & 66,7 & Referência \\
\hline & De carro próprio & 706 & 585 & 82,9 & $1,2(1,1-1,5)^{*}$ \\
\hline & Táxi/Uber & 7 & 6 & 85,7 & $1,3(0,9-1,8)$ \\
\hline & A pé & 52 & 46 & 88,5 & $1,3(1,1-1,6)^{*}$ \\
\hline & De carona & 79 & 65 & 82,3 & $1,2(1,0-1,5)$ \\
\hline & Outra forma & 107 & 86 & 80,4 & $1,2(0,9-1,5)$ \\
\hline \multirow{3}{*}{$\begin{array}{l}\text { Facilidade para } \\
\text { estacionar }\end{array}$} & Não & 209 & 155 & 74,2 & Referência \\
\hline & Sim & 568 & 489 & 86,1 & $1,2(1,1-1,3)^{*}$ \\
\hline & Não veio de carro & 198 & 153 & 77,3 & $1,0(0,9-1,2)$ \\
\hline
\end{tabular}

(a) Associações significativas, quando o IC95\% não cobre o valor 1, são marcadas por um asterisco $(*)$, similar a $p<0,05$.

Os resultados mostrados na Tabela 19 indicam que as frequências de participantes que declararam estar "totalmente satisfeitos" estão associadas com a idade (pessoas mais idosas, com idades maiores que 50 anos, tendem a estarem menos satisfeitas), o meio de transporte que usou para chegar ao Hemocentro (pessoas que usam ônibus mostram-se menos satisfeitas) e facilidade para estacionar (pessoas que não encontraram lugar para estacionar mostram-se menos satisfeitas). 


\section{Gráfico desempenho-importância (GDI)}

O gráfico desempenho-importância (GDI) apresentado na Figura 10 tem no eixo das ordenadas as correlações policóricas entre as respostas a cada item (mostradas na Figura 8) e no eixo das abscissas os desempenhos dos atributos de satisfação, dados pelas médias das respostas a cada um dos 25 itens do instrumento (1=muito insatisfeito, 2=insatisfeito, $3=$ regular, $4=$ satisfeito e $5=$ muito satisfeito). Os números mostrados no gráfico referem-se aos números dos itens, como descrito na Tabela 16.

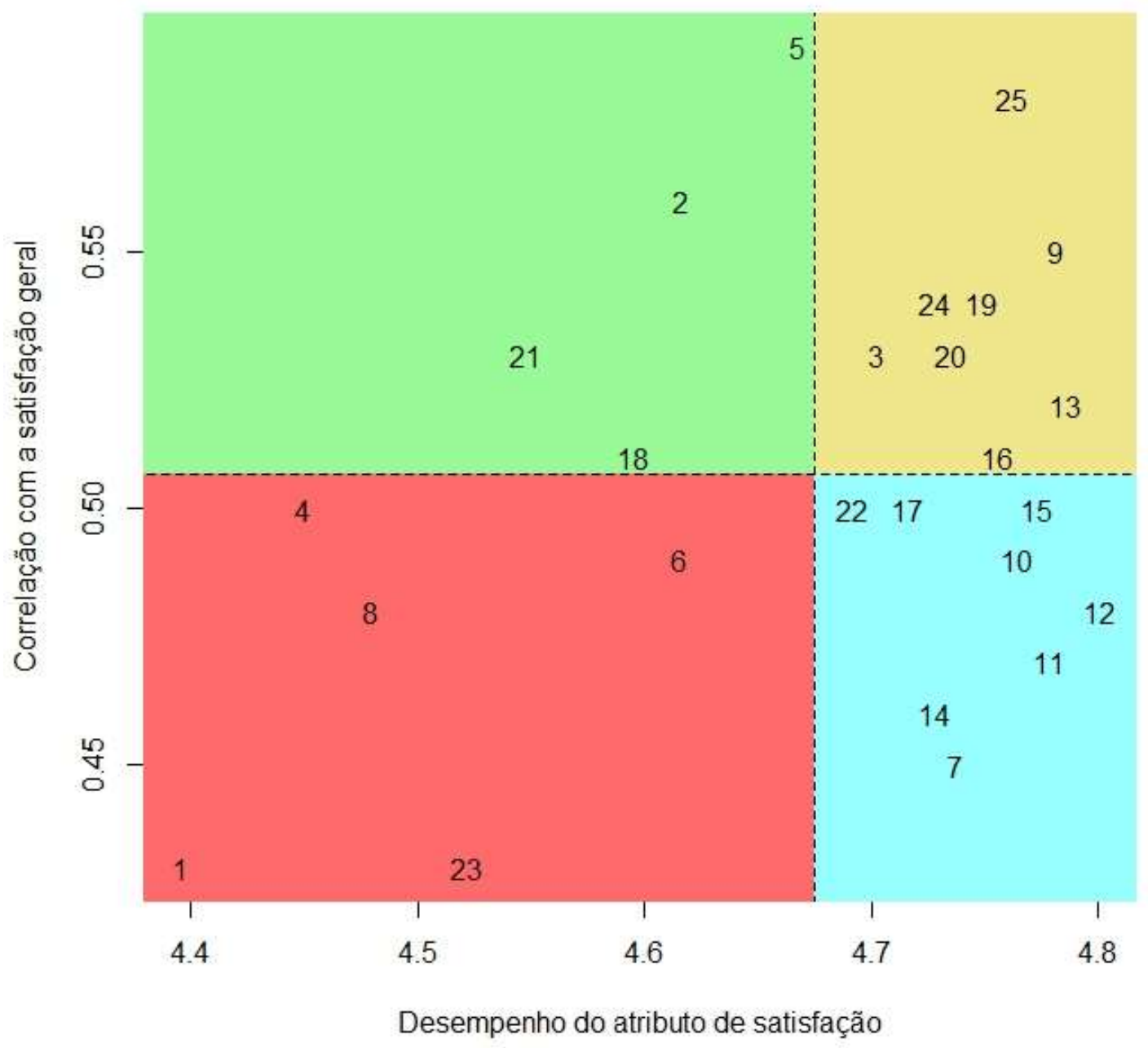

Figura 10. Gráfico desempenho-importância para os 25 itens que compõem o instrumento de satisfação $(n=1.019)$. 
Entende-se que as correlações entre cada item e a satisfação geral reflete a importância que os doadores dão a cada atributo como formadores da sua satisfação quanto ao serviço como um todo. O GDI é então interpretado como sintetizado no Quadro 2.

\begin{tabular}{|c|c|}
\hline $\begin{array}{l}\text { Quadrante verde } \\
\text { Satisfação baixa, importância alta }\end{array}$ & $\begin{array}{l}\text { Quadrante amarelo } \\
\text { Satisfação alta, importância alta }\end{array}$ \\
\hline $\begin{array}{l}\text { Oportunidades de melhora a curto } \\
\text { prazo }\end{array}$ & $\begin{array}{l}\text { Fatores motivacionais: produzem efeitos } \\
\text { positivos quando presentes }\end{array}$ \\
\hline $\begin{array}{l}\text { São atributos que, se melhorados, a } \\
\text { satisfação geral tenderá a aumentar. }\end{array}$ & $\begin{array}{l}\text { São atributos que levam à satisfação geral } \\
\text { quando presentes, e o Hemocentro precisa } \\
\text { de esforços para mantê-los. }\end{array}$ \\
\hline Quadrante vermelho & Quadrante azul \\
\hline Satisfação baixa, importância baixa & Satisfação alta, importância baixa \\
\hline $\begin{array}{l}\text { Oportunidades de melhora a longo } \\
\text { prazo }\end{array}$ & $\begin{array}{l}\text { Fatores higiênicos: podem produzir } \\
\text { efeitos negativos quando ausentes }\end{array}$ \\
\hline $\begin{array}{l}\text { São atributos que, se melhorados, a } \\
\text { satisfação geral poderá não aumentar, mas } \\
\text { devem ser monitorados, e precisam estar } \\
\text { presentes quando propostas novas versões } \\
\text { de questionários de satisfação. }\end{array}$ & $\begin{array}{l}\text { Não são atributos que levam à satisfação } \\
\text { geral quando presentes, mas os doadores } \\
\text { podem ficar insatisfeitos se o Hemocentro } \\
\text { deixar de mantê-los. }\end{array}$ \\
\hline
\end{tabular}

Quadro 2. Interpretação do GDI.

Assim, segue a interpretação para os resultados do instrumento de satisfação:

- Quadrante verde: itens 2, 5 e 21 (principalmente) e 18.

2. O atendimento do pessoal da recepção

5. O atendimento do profissional que mediu a minha pressão antes da entrevista

18. O lanche que me ofereceram depois da doação 
21. O atendimento do funcionário que trabalha na copa

Este quadrante agrupou três itens relativos ao atendimento de funcionários (2, 5 e 21), em três setores e atividades diferentes. Desde os resultados obtidos dos grupos focais, de fato, observa-se à valorização que o doador de sangue atribui ao atendimento que recebe no serviço. São estes os itens prioritários para ações de busca de qualidade. Entende-se que o item 18 é importante, mas por posicionar-se mais próximo à média, não teria a mesma prioridade que os itens $(2,5$ e 21$)$.

- Quadrante amarelo: itens 3, 9, 13, 16, 19, 20, 24 e 25

3. A gentileza do profissional que fez a entrevista antes da doação

9. A gentileza do profissional que coletou o meu sangue

13. A atenção que o profissional que coleta o sangue tem naquilo que está fazendo

16. A limpeza da copa (onde servem o lanche)

19. A quantidade de profissionais disponíveis para me atender

20. A competência profissional das pessoas que trabalham no Hemocentro

24. O esforço dos profissionais para eu me sentir à vontade

25. O respeito com que as pessoas me tratam no Hemocentro

A não ser o item 16, observa-se que este quadrante agrupou essencialmente itens voltados às relações entre o doador e os funcionários do Hemocentro, que não apareceram no quadrante verde. Os doadores estão satisfeitos com estes itens, sendo essenciais as ações que busquem manter a qualidade do atendimento e serviços prestados por estes profissionais. Em adição, observa-se que os doadores valorizam a limpeza da copa, ação que deve ser mantida. Destaca-se que o item 25 é aquele que possui maior correlação com a satisfação geral, dentre os itens deste quadrante, o que 
sugere que ser tratado com respeito é uma expectativa forte dos doadores de sangue quando comparecem ao Hemocentro.

- Quadrante vermelho: itens 1, 4, 6, 8, 18 e 23.

1. A facilidade para se chegar ao Hemocentro

4. O tempo gasto durante a entrevista, antes da doação de sangue

6. O conforto da sala onde fiquei esperando ser chamado(a) para doar sangue

8. O tempo que eu tive que esperar para ser chamado(a) para entrar na sala de coleta

23. Os horários de atendimento do Hemocentro ao doador de sangue

Observa-se que este quadrante agrupou essencialmente itens da dimensão acesso/conveniência do instrumento. A facilidade para se chegar ao Hemocentro (item 1) é o item com menor percepção de satisfação, dentre todos do instrumento. $O$ coeficiente de correlação policórica entre este item e a satisfação geral é 0,43 (Figura 8). Entretanto, este coeficiente é de 0,438 para os doadores que chegaram ao Hemocentro de carro próprio, 0,102 para aqueles que chegaram de ônibus, 0,587 para aqueles que foram a pé, 0,434 para aqueles que foram de carona, e 0,427 para aqueles que chegaram de outra forma.

A Tabela 20 mostra que as frequências de doadores que responderam estar "totalmente satisfeitos" em relação à facilidade para se chegar no Hemocentro (item 1) é altamente associada à forma que chegaram ao Hemocentro (aqueles que vieram de ônibus estão menos satisfeitos quanto a este atributo) e à facilidade de encontrar vagas para estacionar (quem relatou não encontrar vaga para estacionar, está menos satisfeito quanto a este atributo). Estes resultados evidenciam que a posição que o item 1 
encontra-se no GDI é sujeita a um efeito moderador do meio em que o doador utilizou para chegar ao Hemocentro, bem como da disponibilidade de vagas para estacionar.

Tabela 20. Top box analysis, item 1 do instrumento de satisfação (facilidade para se chegar no Hemocentro) $(n=1.019)$.

\begin{tabular}{llrrrrr}
\hline \multirow{2}{*}{ Variáveis } & & \multicolumn{3}{c}{ Top box } & Razões \\
Como chegou ao & & Total & $n$ & $\%$ & \\
Hemocentro & A pé & 53 & 35 & 66,0 & Referência \\
& De carro próprio & 704 & 340 & 48,3 & $0,7(0,5-0,9)^{*}$ \\
& Ônibus & 7 & 2 & 28,6 & $0,4(0,1-1,4)$ \\
& Táxi/Uber & 55 & 25 & 45,4 & $0,7(0,4-0,9)^{*}$ \\
& De carona & 80 & 39 & 48,8 & $0,7(0,5-1,0)$ \\
& Outra forma & 107 & 51 & 47,7 & $0,7(0,5-0,9)^{*}$ \\
Facilidade para & & & & & \\
estacionar & Não & 209 & 65 & 31,3 & Referência \\
& Sim & 568 & 305 & 53,7 & $1,7(1,4-2,1)^{*}$ \\
& Não veio de carro & 198 & 104 & 52,8 & $1,7(1,3-2,1)^{*}$ \\
& & & & & \\
\hline
\end{tabular}

- Quadrante azul: itens 5, 7, 10, 11, 12, 14, 15, 17, 21 e 22.

5. O atendimento do profissional que mediu a minha pressão antes da entrevista

7. A limpeza das salas que eu estive antes de ser chamado para coletar sangue

10. A segurança que o Hemocentro me passa quanto ao material usado para a coleta

11. O cuidado que eu sinto estar recebendo, durante a doação de sangue

12. A higiene da sala de coleta

14. O conforto da sala de coleta

15. O tempo gasto durante a doação de sangue, quando já estava na sala de coleta

17. As explicações que os profissionais me dão em relação a tudo que eu quero entender

21. O atendimento do funcionário que trabalha na copa

22. A disponibilidade dos profissionais em me ouvir, em qualquer momento 
Nota-se que este quadrante envolve itens dos três domínios da satisfação (acesso/conveniência, aspectos técnicos e aspectos interpessoais). Estes itens, como fatores higiênicos, devem receber esforços para serem mantidos, dado que podem ter efeito negativo sobre a satisfação geral caso ausentes. 


\section{Discussão}

O instrumento proposto é uma extensão da proposta de Borges et al. (2005), sendo as principais diferenças:

- O novo instrumento inclui uma pergunta sobre a satisfação geral, que não é contemplada no instrumento de Borges et al. (2005). Esta pergunta permite uma mensuração direta da satisfação do doador. A mensuração da satisfação geral como a resultante de um conjunto de itens pode desconsiderar atributos de não-conformidade não listados no instrumento. Em adição, a medida de satisfação geral permite a geração dos gráficos GDI, úteis para apontar os atributos da qualidade que devem ser alvos de ações voltadas à qualidade do serviço.

- Não são considerados itens não-modificáveis, ou que não pretendem ser modificados pela instituição. Assim, o item "espaço físico do Hemocentro" só tem valor em um instrumento de satisfação se há o interesse em ampliar o espaço caso seja responsável por reduzir a satisfação geral.

- Ampliou-se de 18 para 25 itens.

- As respostas aos itens agora referem-se diretamente à satisfação, dado que as respostas vão de "completamente insatisfeito" a "completamente satisfeito". No instrumento de Borges et al. (2005), os itens são apresentados como afirmativas e as respostas vão de "totalmente errado" a "totalmente certo".

- As respostas aos itens são apresentadas em uma escala de 5 opções, permitindo uma resposta "neutra", enquanto o instrumento de Borges et al. (2005) oferecia aos doadores de sangue 4 opções, sem a resposta "neutra". 
Os grupos focais objetivaram a busca de atributos de satisfação de poderiam ser acrescentados no instrumento. Como resultado, observou-se que os participantes destacaram atributos voltados ao atendimento, acolhimento, comprometimento, profissionalismo e outros aspectos desejáveis à equipe de profissionais do Hemocentro, com pouca valorização à atributos ligados à estrutura física do serviço. Esta seria uma evidência que a expectativa do doador quanto ao serviço reside principalmente quando ao atendimento dos profissionais, sendo a satisfação relacionada ao quanto ele será bem recebido e acolhido pela equipe, com pouca valorização da estrutura material. Assim, tornou-se essencial para a composição do instrumento itens que abrangessem as diferentes formas de atendimento ao doador, por parte da equipe, em todas as etapas do processo de doação de sangue.

Uma vez preparada a primeira versão do novo instrumento (Figuras 2 e 3), o painel de especialistas foi essencial para a revisão do instrumento, resultando na modificação do texto de sete itens da primeira versão. Nesta etapa da pesquisa, os juízes já previam alguma complexidade na definição da estrutura fatorial do instrumento, dado que alguns itens apresentaram valores de factorial validity index (FVI) que sugeriam a inadequação em relação aos domínios a eles previstos (acesso/conveniência, aspectos técnicos, aspectos interpessoais).

A Etapa 3, onde foi feito o pré-teste do instrumento, foi importante principalmente para indicar que os doadores poderiam confundir-se ao preencher as respostas aos itens, por não estar suficientemente explícito que a escala vai de "muito insatisfeito" a "muito satisfeito". Isso motivou a inserção dos emoticons no instrumento, 
de modo que este problema pareceu atenuar-se na fase seguinte da pesquisa, quando um número maior de doadores respondeu ao instrumento.

A Etapa 4 mostrou uma alta consistência interna do instrumento, evidenciada pelo coeficiente alfa de Cronbach $(0,985)$. Por outro lado, a análise fatorial exploratória não mostrou uma clara estrutura fatorial dos 25 itens que compõem o instrumento. As cargas fatoriais, apresentadas na Tabela 18, para uma solução de três fatores, não são compatíveis com os domínios previstos para o instrumento.

Em uma etapa adicional, objetivando uma interpretação do instrumento, uma top box analysis considerando a questão de satisfação geral mostrou que o percentual de doadores que se consideram muito satisfeitos com o serviço é menor, entre os doadores mais idosos, e guarda uma profunda relação com o acesso do doador ao Hemocentro. Doadores que dependem de ônibus demoram, em média, 50 minutos para chegar ao Hemocentro, enquanto o tempo usado por quem tem carro é, em média, apenas de 17,7 minutos (Tabela 15). A Tabela 19 mostra que os doadores que usam ônibus como transporte apresentam menor satisfação geral que os demais, assim como aqueles que tiveram dificuldades para estacionar o carro. Esse resultado pode ser fruto de um "efeito horn", que é a tendência em estender uma avaliação negativa para os outros itens da avaliação, sem fazer uma análise adequada de cada um dos itens individualmente. Em outras palavras, se o deslocamento ao Hemocentro resultou em uma experiência negativa, ela pode se estender para a avaliação dos demais atributos da qualidade expostos no instrumento. 
A facilidade para se chegar ao Hemocentro (item 1) acabou constituindo um item duvidoso para a proposta de um instrumento para a avaliação da satisfação do doador de sangue. Nota-se um content vality ratio (CVR) baixo, como atribuído na Etapa 2 pelos juízes (ver Tabela 4), uma correlação entre o item e o total relativamente baixa, conforme a análise de fidedignidade exibida na Tabela 17, e uma correlação com a satisfação geral também relativamente baixa (0,43, ver Figura 8). Dentre os 25 itens que compõem o instrumento, como atributos da satisfação, nota-se que, com exceção do item 1, todos os demais descrevem atributos uniformemente oferecidos pelo Hemocentro aos doadores. Em outras palavras, como exemplos, o atendimento do pessoal da recepção, a gentileza dos profissionais, a higiene e o conforto das salas, são atributos que são oferecidos a todos que compareceram ao serviço, sem que exista alguma distinção quanto a alguma característica ou especificidade dos doadores. A facilidade para se chegar ao Hemocentro, por outro lado, é um atributo que traz uma profunda relação com os meios de locomoção que são acessíveis aos doadores (Tabela 20), o que constitui um fator extrínseco ao serviço oferecido pela instituição. Isso não tira do Hemocentro a responsabilidade em planejar estratégias para o incremento da satisfação quanto a este atributo, dado que o acesso ao serviço é importante para a captação de doadores e manutenção de estoques. Por outro lado, pode ser adequado estudar o acesso ao Hemocentro como atributo da qualidade de forma específica, sem a inclusão do item 1 no GDI. Neste caso, é adequado rotular o domínio "acesso/conveniência" apenas como "conveniência". No Apêndice V, temos um GDI retirando o item 1, e observamos que não há mudanças importantes em relação ao discutido aqui, na Subseção 5.5 (as coordenadas no gráfico não se alteram, mas há mudanças nas médias, que definem os quadrantes). 
Consideramos que a ausência de uma explícita estrutura fatorial dos 25 itens que compõem o instrumento de satisfação (Tabela 18) não descarta a ideia que o instrumento possui validade, mas informa que não há uma compreensível estrutura de correlação entre os itens que pertencem a cada um dos domínios pretendidos. Assim, entendemos que os itens contidos em cada domínio não se homogeneízam entre si para compor um domínio específico, como ocorre tradicionalmente na avaliação psicométrica dos instrumentos usados para as escalas de mensuração ou classificação de comportamentos, atitudes, conhecimentos, qualidade de vida e outras dimensões de interesse. Por outro lado, o GDI parece classificar, de certa forma, os atributos da satisfação conforme os domínios inicialmente propostos, quando visualizados os seus quadrantes. Os agrupamentos dos itens não se dariam, então, de acordo com as estruturas de correlações entre as suas respostas, mas de acordo com a utilidade das informações contidas para a tomada de decisões estratégicas para o incremento da satisfação do doador. Como exemplo, no domínio de aspectos interpessoais, o doador pode ter percepções distintas quanto ao atendimento dos profissionais que atendem na recepção, que trabalham na copa, que coletam o sangue e que fazem a entrevista, o que não gera uma estrutura de correlação que se torna nítida na análise fatorial, mas isso não significa que há necessariamente um equívoco na conceituação do domínio. Devido a estas considerações, descartamos o uso de algumas possibilidades tradicionais em avaliação psicométrica, com a análise fatorial confirmatória.

Como ferramenta de descrição dos dados obtidos pela aplicação do instrumento proposto, entendemos que o uso do GDI é também vantajoso em relação à facilidade encontrada para sua confecção e interpretação. Para um serviço de hemoterapia, há apenas a necessidade de um programa computacional que organize e tabule os dados, e 
então gere as médias das respostas aos itens e a matriz de correlações policóricas. Apesar de usarmos nas presentes análises o programa SAS, o programa R é de domínio público, gratuito, e capaz de gerar as correlações policóricas. O uso do GDI não requer conhecimentos estatísticos específicos, que tragam obstáculos a um profissional não habituado com técnicas de análises de dados (sendo a geração das correlações policórias obtidas por softwares, sua interpretação é simples, considerando que quanto mais próxima a 1, maior é a correlação entre o item e a satisfação geral).

Além dos questionamentos apresentados para a facilidade para se chegar ao Hemocentro como atributo da satisfação, outra limitação importante do presente estudo é a ausência de estudos publicados que mostrem o desempenho de instrumentos semelhantes, voltados para a avaliação da satisfação do doador de sangue. Isto não nos permite uma comparação dos resultados aqui apresentados com outros da literatura, o que fortaleceria as evidências da utilidade e capacidade do instrumento proposto em avaliar a satisfação. Como outras limitações, é importante questionar se os resultados estão sujeitos a um efeito halo, ou seja, uma percepção positiva de algum aspecto que o doador valoriza, tornaria todos os atributos também satisfatórios, mesmo que exista alguma má conformidade visível. Observa-se que 31,2\% dos doadores que participaram da Etapa 4 da pesquisa avaliaram todos os 25 itens do instrumento como muito satisfatórios. Menos aparente, um efeito horn também pode estar presente, quando um doador sofre algum evento que o desagradou em uma etapa prévia ou inicial do processo de doação (como a dificuldade para encontrar vagas no estacionamento ou alguma má impressão do seu atendimento na recepção) e passa a ter uma visão negativa quanto a outros itens seguintes. 
Apesar destas limitações, o instrumento proposto pode ser adequado à avaliação da satisfação do doador em outros bancos de sangue. É importante enfatizar que os resultados obtidos da interpretação do GDI e apresentados na Subseção 5.5 são válidos somente para o Núcleo de Hemoterapia de Franca, e são apresentados nesta tese somente para ilustrar o desempenho e utilidade do instrumento proposto. Não é possível inferir que os achados da interpretação do GDI sejam aplicáveis a outros bancos de sangue. Isso reforça que, a partir da aplicação do GDI, um banco de sangue que decidiu adotar o instrumento proposto pode (e deve) fazer adaptações constantes dos 25 itens para suas realidades e necessidades locais, conforme as más conformidades quanto aos atributos da qualidade sejam solucionadas pela equipe responsável pela qualidade do serviço.

Assim, para a aplicação do instrumento proposto em um banco de sangue ou serviço de hemoterapia, sugerimos:

1. A aplicação do instrumento, como descrito nas Figuras 6 e 7 , por um período específico. Sugerimos o período de um ano, dada a possibilidade de alguma variação sazonal na ocorrência de eventos que possam ter algum efeito na satisfação dos doadores.

2. Em paralelo ao uso do instrumento, a utilização de uma caixa de sugestões e reclamações, em que o doador possa, ao final do processo de doação de sangue, registrar suas percepções positivas e negativas quanto ao serviço prestado. 
3. Terminado o período específico, tabular os dados e gerar o GDI, onde os atributos de satisfação em não conformidade devem ser alvo de políticas de melhoria da qualidade do serviço prestado.

4. Neste momento, compor grupos focais, com doadores de sangue, em que estes poderão fornecer novas informações sobre atributos da satisfação sob a ótica do usuário.

5. Usar as informações obtidas dos grupos focais e da caixa de sugestões e reclamações para propor novos itens que podem ser agregados ao instrumento, mas com o cuidado de não produzir um questionário demasiadamente extenso.

6. Itens que, ao longo do tempo, sistematicamente aparecem no quadrante amarelo do GDI (satisfação alta, importância alta) podem ser substituídos por novos itens, desde que seja pactuado no serviço que haverá estratégias contínuas para a manutenção da qualidade dos atributos correspondentes. Isto é importante, inclusive, para que o número de itens do instrumento não aumente de forma a comprometer sua parcimônia. Entretanto, é importante lembrar que no GDI, qualquer item pode se mover de qualquer um dos quadrantes para outro, e a exclusão de um item do instrumento do quadrante amarelo não deve ser feita sem a garantia da continuidade da qualidade de sua oferta.

7. Ao final de cada período, uma vez adaptado o instrumento, repetir o processo.

Como afirmado na seção de Métodos, nesse processo, vale sempre lembrar que os itens constantes em um instrumento não devem ser destinados à geração de uma 
"medida" da satisfação do doador através da soma dos valores atribuídos às respostas ou outra equação que utilize as respostas aos atributos correspondentes. Essa prática deve ser evitada, dado que uma medida de satisfação assim calculada é enviesada por:

(a) Um índice "alto" de satisfação assim obtido não indica que os doadores estão satisfeitos quanto ao serviço, mas pode estar apenas indicando que os atributos que levam à insatisfação não são contemplados no instrumento (o questionário só conteria atributos avaliados sistematicamente como de satisfação alta). Assim, é possível a um banco de sangue produzir um instrumento que sempre gere um índice alto de satisfação próximo a 100\% se utilizar apenas atributos de satisfação que rotineiramente apareçam nos quadrantes amarelo (satisfação alta, importância alta) ou azul (satisfação alta, importância baixa) do GDI.

(b) Um aumento deste índice de um período para outro não significa que os doadores estão mais satisfeitos, mas indica somente que os itens que geraram menor satisfação devem ter sido melhorados pelo serviço. Se os doadores passaram a estar mais satisfeitos em relação a estes itens, não significa que em geral estão mais satisfeitos, dado que podem surgir outros itens em não conformidade no período seguinte, não contemplados no instrumento.

Assim, o monitoramento da satisfação ao longo do tempo, em termos de um indicador quantitativo e sintético, não deve se basear nos itens do instrumento, mas na questão de satisfação geral. O questionário pode (e deve) se modificar ao longo do tempo, permitindo aos gestores a encontrar no GDI as informações para a tomada de ações que incrementem este indicador. É então esperado que, ao longo do tempo, diferentes bancos de sangue utilizem diferentes conjuntos de atributos ligados à 
satisfação, mas comparações entre os desempenhos de diferentes serviços podem ser feitas através das respostas à questão de satisfação geral. Como sugestão, pode-se utilizar como indicador sintético de satisfação simplesmente a proporção de doadores que responderam nesta questão que estão "totalmente satisfeitos" com o serviço.

Como um comentário final, observamos que o GDI (Figura 10) mostrou que, independentemente do desempenho dos atributos de satisfação (eixo horizontal), as correlações com a satisfação geral mostraram uma tendência a agrupar nos quadrantes superiores (verde e amarelo) os itens relacionados aos aspectos interpessoais, e nos quadrantes inferiores (vermelho e azul) os itens relacionados aos aspectos técnicos e de conveniência. Embora esse fenômeno não tenha sido considerado como hipótese previamente a cada etapa do estudo, há a sugestão que as expectativas dos doadores de sangue sejam essencialmente relacionadas ao bom atendimento dos funcionários, ao acolhimento, à cortesia, ao amparo, sendo que os aspectos relacionados à estrutura física do serviço não seriam prioritários. Portanto, os investimentos em um banco de sangue para a manutenção da qualidade do serviço nunca devem ser direcionados somente aos materiais, espaços físicos e estruturas materiais, mas esforços significativos precisam ser direcionados ao treinamento e motivação das equipes de trabalhadores. 


\section{Conclusão}

Perante a ausência de um instrumento validado que permita avaliar a satisfação do doador de sangue, a presente Tese de Doutorado descreveu o desenvolvimento de um instrumento que pode ser bastante útil quando adotado por um banco de sangue ou serviço de hemoterapia. O instrumento proposto mostrou-se útil para fornecer aos gestores os itens que devem ser melhorados, monitorados ou mantidos, para que os bancos de sangue possam prover aos doadores um serviço que atenda às suas expectativas sintam-se satisfeitos quando ao atendimento. 


\section{Referências Bibliográficas}

Alexandre NM, Coluci MZ. Content validity in the development and adaptation processes of measurement instruments. Ciênc Saúde Coletiva 2011;16(7):3061-8.

Alshmemri M, Shahwan-Akl L, Maude P. Herzberg's two-factor theory. Life Science Journal 2017; 14(5):12-16.

Araújo FMRD, Feliciano KVDO, Mendes MFDM. Aceitabilidade de doadores de sangue no hemocentro público do Recife, Brasil. Ciênc Saúde Coletiva 2011; 16:482332.

Basch CE. Focus group interview: an underutilized research technique for improving theory and practice in health education. Health Educ $Q$ 1987; 14(4): 411-48.

Bland JM, Altman DG. Statistics notes: Cronbach's alpha. BMJ 1997; 314(7080): 572.

Borges VL, Martinez EZ, Bendini MH, Costa MAGF, Ferreira SCL. Avaliação da fidedignidade de um instrumento voltado à satisfação do doador de sangue. Rev Bras Epidemiol 2005; 8(2): 177-86.

Byrne M. The implications of Herzberg's "motivation-hygiene" theory for management in the Irish health sector. Health Care Manag (Frederick). 2006;25(1):4-11.

Cardoso DE, Amorim MM, Mota S, Condeço J. Avaliação da satisfação dos dadores do Instituto Português do Sangue-Centro Regional de Sangue do Porto. Instituto Politécnico do Porto. Escola Superior de Tecnologia da Saúde do Porto - Politema. 2010. Disponível em: http://recipp.ipp.pt/handle/10400.22/1315

Carlini-Cotrim, B. Potencialidades da técnica qualitativa grupo focal em investigação sobre o abuso de substâncias. Rev Saúde Pública 1996; 30(3): 285-93.

Carneiro AR, Lopes MED. Coletânea de Legislação em Hemoterapia e Hematologia. Rio de Janeiro: Sociedade Brasileira de Hematologia e Hemoterapia (SBHH), 2002. 
Crocker L, Llabre M, Miller MD. The generalizability of content validity ratings. $J$. Educ. Meas. 1988; 25:287-99.

Cronbach LJ. Coefficient alpha and the internal structure of tests. Psychometrika 1951; 16: $297-334$.

Dos Santos NLP, Stipp MAC, Leite JL, Nunes AS. The elderly blood donor and the hemotherapic nurses's care. Rev Eletr Enferm. 2008; 10(3):828-34.

Fitzner K. Reliability and validity: a quick review. The Diabetes Educator 2007; 33: 775-80.

Galdeano LE, Rossi LA. Validação de conteúdo diagnóstico: critérios para seleção de expertos. Ciênc Cuid Saúde 2006; 5(1):60-6.

Giacomini L, Lunardi Filho WD. Estratégias para fidelização de doadores de sangue voluntários e habituais. Acta Paul. Enferm. 2010; 23(1):65-72.

Glynn SA, Schreiber GB, Murphy EL, Kessler D, Higgins M, Wright DJ, et al. Factors influencing the decision to donate: racial and ethnic comparisons. Transfusion 2006; 46(6):980-90.

Gondim SMG. Grupos Focais como técnica de investigação qualitativa: desafios metodológicos. Paidéia 2003; 12(24): 149-61.

Grant JS, Davis LL. Selection and use of content experts for instrument development. Res Nurs Health 1997;20(3):269-74.

Guerra CC. Fim da doação remunerada de sangue no Brasil faz 25 anos. Rev. Bras. Hematol. Hemoter 2005; 27(1), 1-3.

Haynes SN, Richard DCS, Kubany ES. Content validity in psychological assessment: a functional approach to concepts and methods. Psychol Assess 1995; 7(3):238-47.

Holgado-Tello FP, Chacón-Moscoso S, Barbero-García I, Vila-Abad E. Polychoric versus Pearson correlations in exploratory and confirmatory factor analysis of ordinal variables. Quality \& Quantity 2010; 44(1): 153. 
Iervolino AS, Pelicioni MCF. A utilização do grupo focal como metodologia qualitativa na promoção da saúde. Rev Esc Enf USP 2001; 35(2): 115-21.

Kezwer G. Dracula wants your blood. Now!. Can Med Assoc J. 2000; 162(2):246-246.

Krueger RA. Focus Group: a pratical guide for applied research. Newbury Park: Sage Publications, 1988.

Lei Federal nº 1075- Dispõe sobre doação voluntária de sangue.

Lei Federal no 4701- Dispõe sobre o exercício da atividade hemoterápica no Brasil e dá outras providências.

Livitz IE, Fox KR, Himawan LK, France CR. A brief motivational interview promotes internal motivation to donate blood among young adults with and without a prior donation history. Transfusion 2017; 57(6): 1527-35.

Ludwig ST, Rodrigues ACM. Doação de sangue: uma visão de marketing. Cad Saúde Pública 2005; 21(3):932-9.

Marantidou O, Loukopoulou L, Zervou E, Martinis G, Egglezou A, Fountouli P, et al. Factors that motivate and hinder blood donation in Greece. Transfus Med. 2007; 17(6):443-50.

Mathew SM, King MR, Glynn SA, Dietz SK, Caswell SL, Schreiber GB. Opinions about donating blood among those who never gave and those who stopped: a focus group assessment. Transfusion 2007; 47(4):729-35.

Ministério da Saúde. Brasil. Caderno de Informação: sangue e hemoderivados: rede física, produção, gastos públicos com hemoterapia e consumo de hemoderivados. Ministério da Saúde. - Brasília: Editora do Ministério da Saúde, 2007.

Ministério da Saúde. Brasil. Caderno de Informação: sangue e hemoderivados: dados de 2015. Ministério da Saúde. - Brasília: Editora do Ministério da Saúde, 2017.

Moog R, Fourné K. Recruitment of prospective donors: what do they expect from a homepage of a blood transfusion service? Transfus Med 2007; 17(4):279-84. 
Morgan, DL. Focus group as qualitative research. Sage university paper series in: Qualitative research methods. Newbury Park: Sage Publications, 1988.

Nguyen DD, Devita DA, Hirschler NV, Murphy EL. Blood donor satisfaction and intention of future donation. Transfusion 2008; 48(4):742-8.

Pereira JCR. Análise de dados qualitativos: estratégias metodológicas para as ciências da saúde, humanas e sociais. $3^{\mathrm{a}}$ ed. São Paulo: Editora da Universidade de São Paulo; 2001.

Pereira JR, Sousa CV, Matos EBD, Rezende LBO, Bueno NX, Dias ÁM. To donate or not donate, that is the question: an analysis of the critical factors of blood donation. Ciênc Saúde Coletiva 2016; 21(8): 2475-84.

Pett MA, Lackey NR, Sullivan JJ. Making sense of factor analysis: The use of factor analysis for instrument development in health care research. Thousand Oaks: Sage Publications, 2003.

Ramirez, AG, Shepperd, J. The use of focus group in health research. Scand. J Primary Healthy Care, suppl.1, p.81-90, 1988.

Ringwald J, Zimmermann R, Eckstein R. Keys to open the door for blood donors to return. Transfus Med Rev 2010; 24(4):295-304.

Rodrigues RSM, Reibnitz KS. Estratégias de captação de doadores de sangue: uma revisão integrativa da literatura. Texto Contexto - Enferm 2011; 20(2): 384-391.

Rubio DM, Berg-Weger M, Tebb SS, Lee ES, Rauch S. Objectifying content validity: Conducting a content validity study in social work research. Social Work Research $2003 ; 27(2), 94-104$.

Schlumpf KS, Glynn SA, Schreiber GB, Wright DJ, Randolph Steele W, et al. Factors influencing donor return. Transfusion 2008; 48(2):264-72.

Schmidt FL, Hunter JE, Urry VW. Statistical power in criterion-related validation studies. J Appl Psychol 1976; 61(4):473-85.

Skove T, Deddens J, Petersen MR, Endahl L. Prevalence proportion ratios: estimation and hypothesis testing. Int J Epidemiol 1998; 27(1):91-5. 
Sobreira de Moura A, Teixeira Moreira C, Antero Machado C, Vasconcelos JA, Antero Sousa Machado MDF. Doador de sangue habitual e fidelizado: fatores motivacionais de adesão ao programa. Rev Bras Promoç Saúde 2006; 19(2): 61-7.

Suemnig A, Konerding U, Hron G, Lubenow N, Alpen U, Hoffmann W, Kohlmann T, Greinacher A. Motivational factors for blood donation in first-time donors and repeat donors: a cross-sectional study in West Pomerania. Transfus Med 2017; 27(6); 413-20.

Tison GH, Liu C, Ren F, Nelson K, Shan H. Influences of general and traditional Chinese beliefs on the decision to donate blood among employer organized and volunteer donors in Beijing, China. Transfusion 2007; 47(10):1871-9.

Wilson FR., Pan W, Schumsky DA. Recalculation of the critical values for Lawshe's content validity ratio. Meas Eval Couns Dev 2012; 45(3):197-210. 
Apêndice I

Termo de Consentimento Livre e Esclarecido (TCLE) para os participantes dos grupos focais. 


\title{
TERMO DE CONSENTIMENTO LIVRE E ESCLARECIDO
}

\author{
Título da Pesquisa: "Construção e Validação de um instrumento voltado à satisfação do Doador de \\ Sangue - Uso de Grupos Focais"
}

Pesquisadores responsáveis: Ana Carolina Garcia Braz Trovão - Enfermeira do Núcleo de Hemoterapia de Franca (COREn 203551), estudante de Doutorado em Saúde na Comunidade da Faculdade de Medicina de Ribeirão Preto, Universidade de São Paulo (USP). Ribeirão Preto, Av. Bandeirantes, 3900, 14049-900, Ribeirão Preto/SP, Telefones (16) 3402-5000 ou (16) 99118-0288. Edson Zangiacomi Martinez - Professor do Departamento de Medicina Social da Faculdade de Medicina de Ribeirão Preto, Universidade de São Paulo (USP), Ribeirão Preto, Av. Bandeirantes, 3900, 14049-900, Ribeirão Preto/SP, Telefone: (16) 36022569.

Comitê de Ética em Pesquisa do Hospital das Clínicas da Faculdade de Medicina de Ribeirão Preto (USP): (16) $3602-2228$

Esclarecimentos ao participante da pesquisa: $O(A)$ Senhor(a) está sendo convidado(a) a participar desta pesquisa, como participante de um grupo de dez participantes (chamado "grupo focal") na etapa de construção de um instrumento capaz de medir a satisfação do doador de sangue. Como é um convite, ninguém é obrigado a participar. $\mathrm{O}(\mathrm{A})$ senhor(a) pode desistir de participar a qualquer momento.

Objetivos da pesquisa: A pesquisa pretende construir um instrumento capaz de avaliar a satisfação do doador de sangue. A manutenção dos estoques de sangue no Brasil é um desafio constante nos serviços de hemoterapia e estratégias de fidelização dos doadores e que aumentem a conveniência a novas doações são necessárias. Logo, conhecer o que deixa o doador satisfeito no serviço é fundamental.

Procedimentos: Com o objetivo de construir um instrumento capaz de medir a satisfação do doador de sangue durante seu atendimento, serão realizadas reuniões de grupo com alguns doadores para que possa ser discutido o que os tornam satisfeitos e o que os tornam insatisfeitos quando realizam a doação de sangue. Durante essa reunião, a pesquisadora ficará atenta e registrará tudo o que for dito pelos doadores para construir os itens do questionário de satisfação, pois podem surgir situações que ainda não foram contempladas em instrumentos de satisfação já existentes.

Riscos e desconfortos: Considera-se que os riscos ao participar do estudo são mínimos, uma vez que pode haver algum constrangimento durante a reunião do grupo. Lembramos que o(a) senhor(a) não é obrigado a responder a nenhuma pergunta se não quiser. $O$ preenchimento destes questionários não representa qualquer risco de ordem física. Qualquer sujeito de pesquisa tem direito a indenização conforme as leis vigentes no país, caso ocorra dano decorrente de participação na pesquisa.

Benefícios: Sua participação é importante para o desenvolvimento desta pesquisa. Ao participar, o(a) senhor(a) não receberá nenhum benefício direto. Não está prevista nenhuma forma de compensação ou remuneração pela participação no estudo. Entretanto, espera-se que este estudo traga informações importantes para as futuras pesquisas em saúde, dado que ela será bastante importante para entender o que os serviços de hemoterapia podem fazer para melhorar o atendimento ao doador de sangue. 
Confidencialidade da pesquisa: As informações obtidas serão analisadas apenas pelos pesquisadores responsáveis. Futuramente, os resultados serão apresentados em congressos e/ou publicados em revistas científicas, ficando garantido que o(a) senhor(a) não será identificado(a), ou seja, seu nome não será divulgado.

Aceite em participar do estudo: Após estes esclarecimentos, solicito o seu consentimento de forma livre para participar desta pesquisa. Ao assinar este documento, o(a) senhor(a) consente em participar, mas tem a liberdade de sair da pesquisa em qualquer momento. As informações fornecidas pelo(a) senhor(a) são confidenciais e de conhecimento apenas do pesquisador responsável. Os sujeitos da pesquisa não serão identificados em nenhum momento, mesmo quando os resultados desta pesquisa forem divulgados.

A qualquer momento, os pesquisadores responderão a qualquer pergunta ou esclarecimento sobre a pesquisa. Os pesquisadores estarão à sua disposição para isto, no telefone (16) 3402-5000 e celular (16) 99118-0288 (Ana Carolina Garcia Braz Trovão) ou (16)3602.2569 (Prof. Edson Zangiacomi Martinez). Além do contato dos pesquisadores, o Comitê de Ética em Pesquisa (CEP) do Hospital das Clínicas de Ribeirão Preto pode ser contatado pelo telefone (16)3602-2228, em caso de questões éticas relacionadas à pesquisa.

Este documento é elaborado em duas vias, devendo uma ficar o(a) senhor(a) e outra com os pesquisadores responsáveis.

Ribeirão Preto, de de

Pesquisador(a) Responsável

Ribeirão Preto, de de

Participante da Pesquisa

Nome do participante: 


\section{Apêndice II}

Ficha elaborada para os juízes anotarem suas classificações segundo a relevância dos itens, a clareza, a estrutura dos domínios e a abrangência da medida 
Questionário de satisfação do doador de sangue - validade de conteúdo e fatorial

Idade:

Tempo de experiência em serviço de hemoterapia ou banco de sangue: (anos)

Cidade em que trabalha:

Curso de graduação:

Maior titulação: $\square$ Graduação $\quad \square$ Especialização $\quad \square$ Mestrado (completo ou em andamento) $\square$ Doutorado (completo ou em andamento)

Os domínios do questionário de satisfação foram assim definidos:

Acesso/conveniência: Trata a capacidade do Hemocentro em prover os serviços necessários no tempo e lugar adequados aos doadores.

Aspectos técnicos: Relacionam-se à satisfação do doador diante de situações de interação com o ambiente físico e organizacional do Hemocentro.

Aspectos interpessoais: Relacionam-se à satisfação do doador quando em contato com os funcionários do Hemocentro.

\begin{tabular}{|c|c|c|c|}
\hline Item & $\begin{array}{c}\text { Relevância do item para a } \\
\text { medida da satisfação do } \\
\text { doador de sangue }\end{array}$ & Clareza do item em sua escrita & $\begin{array}{c}\text { A qual domínio este item } \\
\text { pertence? }\end{array}$ \\
\hline $\begin{array}{l}1 . \\
\text { A facilidade para se chegar ao } \\
\text { Hemocentro }\end{array}$ & $\begin{array}{l}\text { ( ) essencial } \\
\text { ( ) útil, mas não essencial } \\
\text { ( ) desnecessário }\end{array}$ & $\begin{array}{l}\text { ( ) o item é bastante claro } \\
\text { ( ) é necessária uma pequena revisão } \\
\text { ( ) é necessária uma substancial revisão } \\
\text { Sugestão para deixar o item mais claro: }\end{array}$ & $\begin{array}{l}\text { ( ) acesso/conveniência } \\
(\text { ) aspectos técnicos } \\
(\text { ) aspectos interpessoais } \\
(\quad \text { ) nenhum destes domínios }\end{array}$ \\
\hline $\begin{array}{l}2 . \\
\text { O atendimento do pessoal da } \\
\text { recepção }\end{array}$ & $\begin{array}{l}\text { ( ) essencial } \\
\text { ( ) útil, mas não essencial } \\
\text { ( ) desnecessário }\end{array}$ & $\begin{array}{l}\text { ( ) o item é bastante claro } \\
\text { ( ) é necessária uma pequena revisão } \\
\text { ( ) é necessária uma substancial revisão } \\
\text { Sugestão para deixar o item mais claro: }\end{array}$ & $\begin{array}{l}\text { ( ) acesso/conveniência } \\
\text { ( ) aspectos técnicos } \\
\text { ( ) aspectos interpessoais } \\
\text { ( ) nenhum destes domínios }\end{array}$ \\
\hline
\end{tabular}




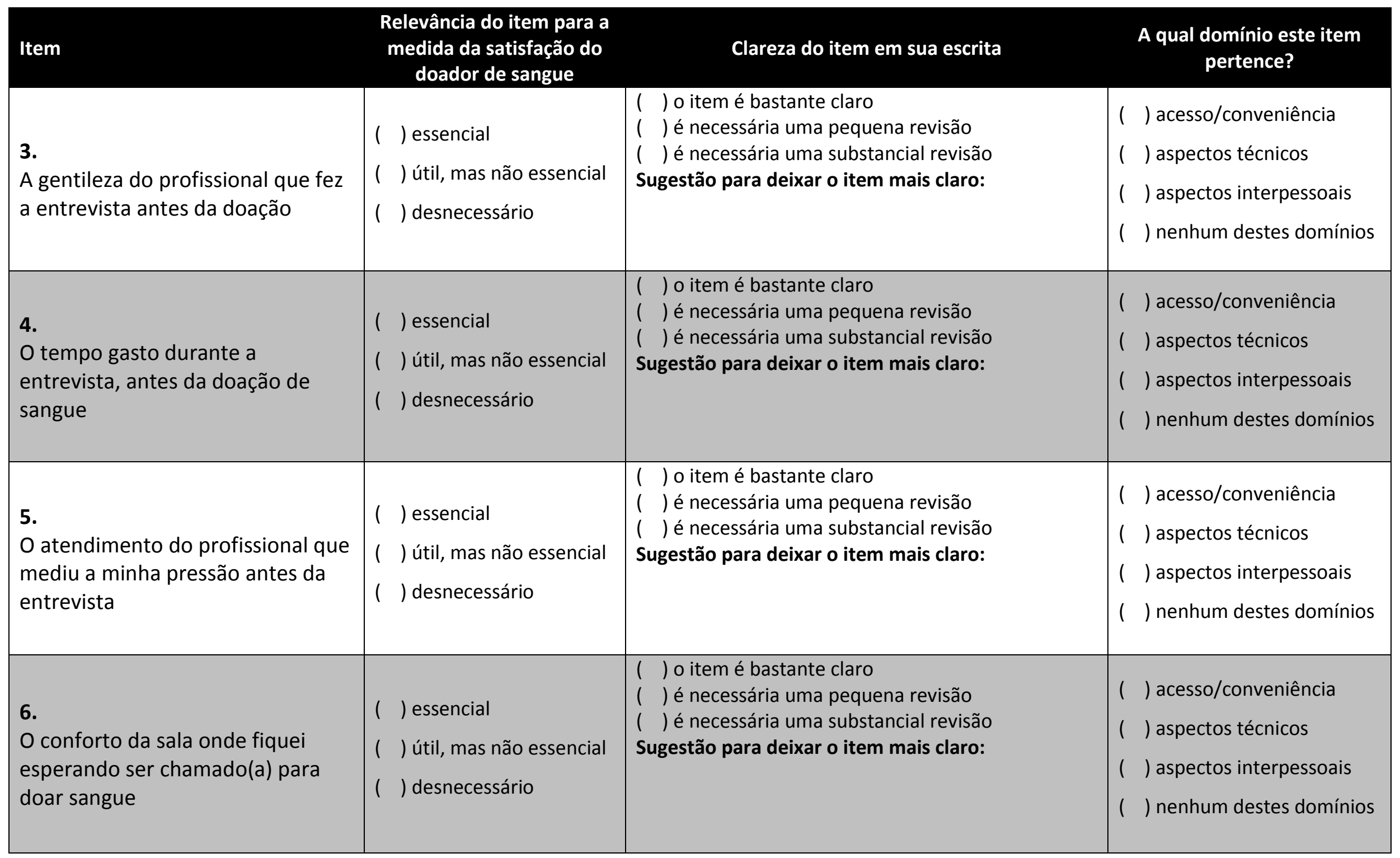




\begin{tabular}{|c|c|c|c|}
\hline Item & $\begin{array}{l}\text { Relevância do item para a } \\
\text { medida da satisfação do } \\
\text { doador de sangue }\end{array}$ & Clareza do item em sua escrita & $\begin{array}{c}\text { A qual domínio este item } \\
\text { pertence? }\end{array}$ \\
\hline $\begin{array}{l}7 . \\
\text { A limpeza das salas que eu estive } \\
\text { antes de ser chamado para coletar } \\
\text { sangue }\end{array}$ & $\begin{array}{l}\text { ( ) essencial } \\
\text { ( ) útil, mas não essencial } \\
\text { ( ) desnecessário }\end{array}$ & $\begin{array}{l}\text { ( ) o item é bastante claro } \\
\text { ( ) é necessária uma pequena revisão } \\
\text { ( ) é necessária uma substancial revisão } \\
\text { Sugestão para deixar o item mais claro: }\end{array}$ & $\begin{array}{l}(\text { ) acesso/conveniência } \\
(\text { ) aspectos técnicos } \\
(\text { ) aspectos interpessoais } \\
(\quad \text { ) nenhum destes domínios }\end{array}$ \\
\hline $\begin{array}{l}8 . \\
\text { O tempo que eu tive que esperar } \\
\text { para ser chamado(a) para entrar } \\
\text { na sala de coleta }\end{array}$ & $\begin{array}{l}\text { ( ) essencial } \\
\text { ( ) útil, mas não essencial } \\
\text { ( ) desnecessário }\end{array}$ & $\begin{array}{l}\text { ( ) o item é bastante claro } \\
\text { ( ) é necessária uma pequena revisão } \\
\text { ( ) é necessária uma substancial revisão } \\
\text { Sugestão para deixar o item mais claro: }\end{array}$ & $\begin{array}{l}\text { ( ) acesso/conveniência } \\
(\text { ) aspectos técnicos } \\
(\text { ) aspectos interpessoais } \\
(\quad \text { ) nenhum destes domínios }\end{array}$ \\
\hline $\begin{array}{l}10 . \\
\text { A segurança que o Hemocentro } \\
\text { me passa quanto ao material } \\
\text { usado para a coleta }\end{array}$ & $\begin{array}{l}\text { ( ) essencial } \\
\text { ( ) útil, mas não essencial } \\
\text { ( ) desnecessário }\end{array}$ & $\begin{array}{l}\text { ( ) o item é bastante claro } \\
\text { ( ) é necessária uma pequena revisão } \\
\text { ( ) é necessária uma substancial revisão } \\
\text { Sugestão para deixar o item mais claro: }\end{array}$ & $\begin{array}{l}\text { ( ) acesso/conveniência } \\
(\text { ) aspectos técnicos } \\
(\text { ) aspectos interpessoais } \\
(\quad) \text { nenhum destes domínios }\end{array}$ \\
\hline
\end{tabular}




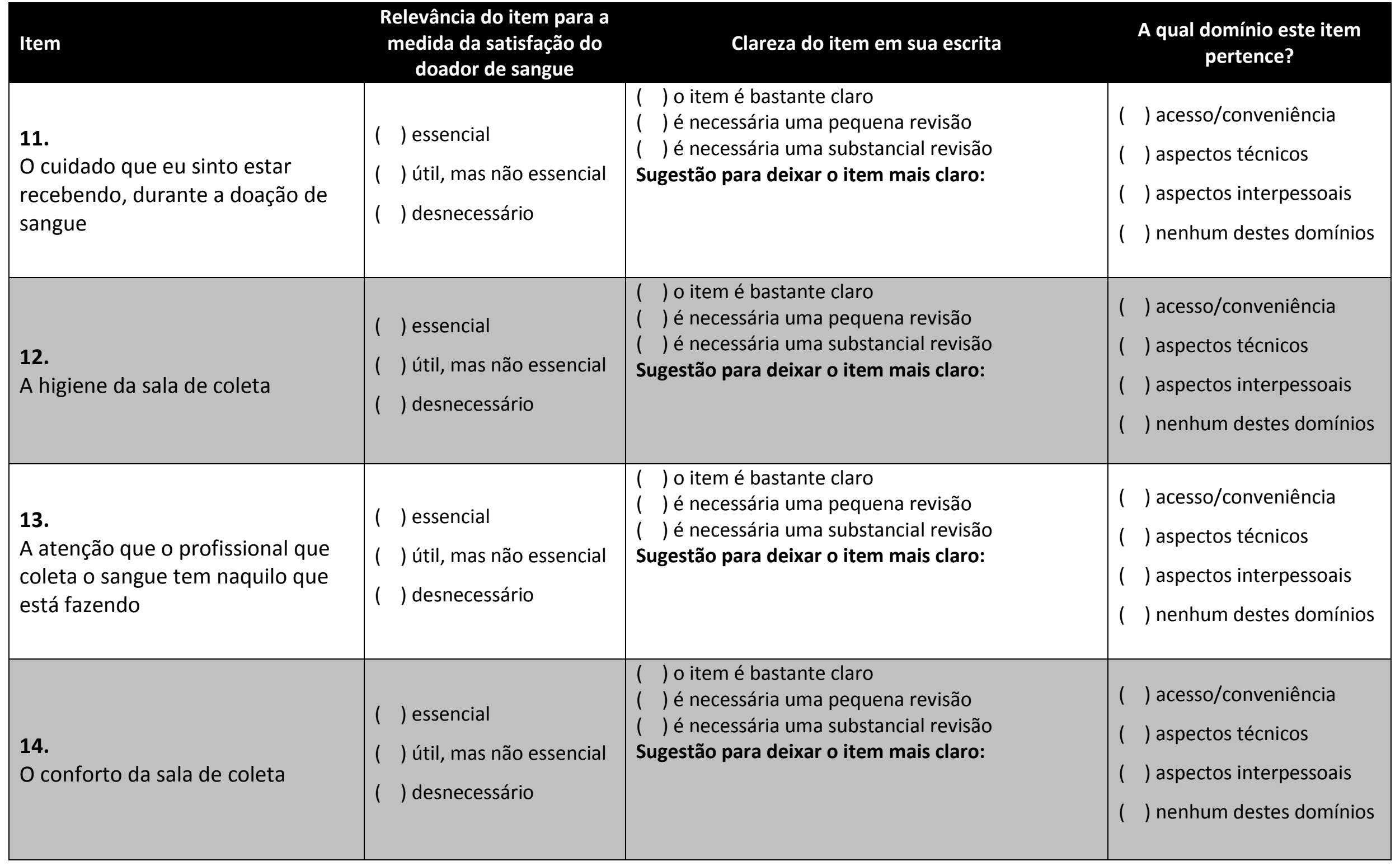




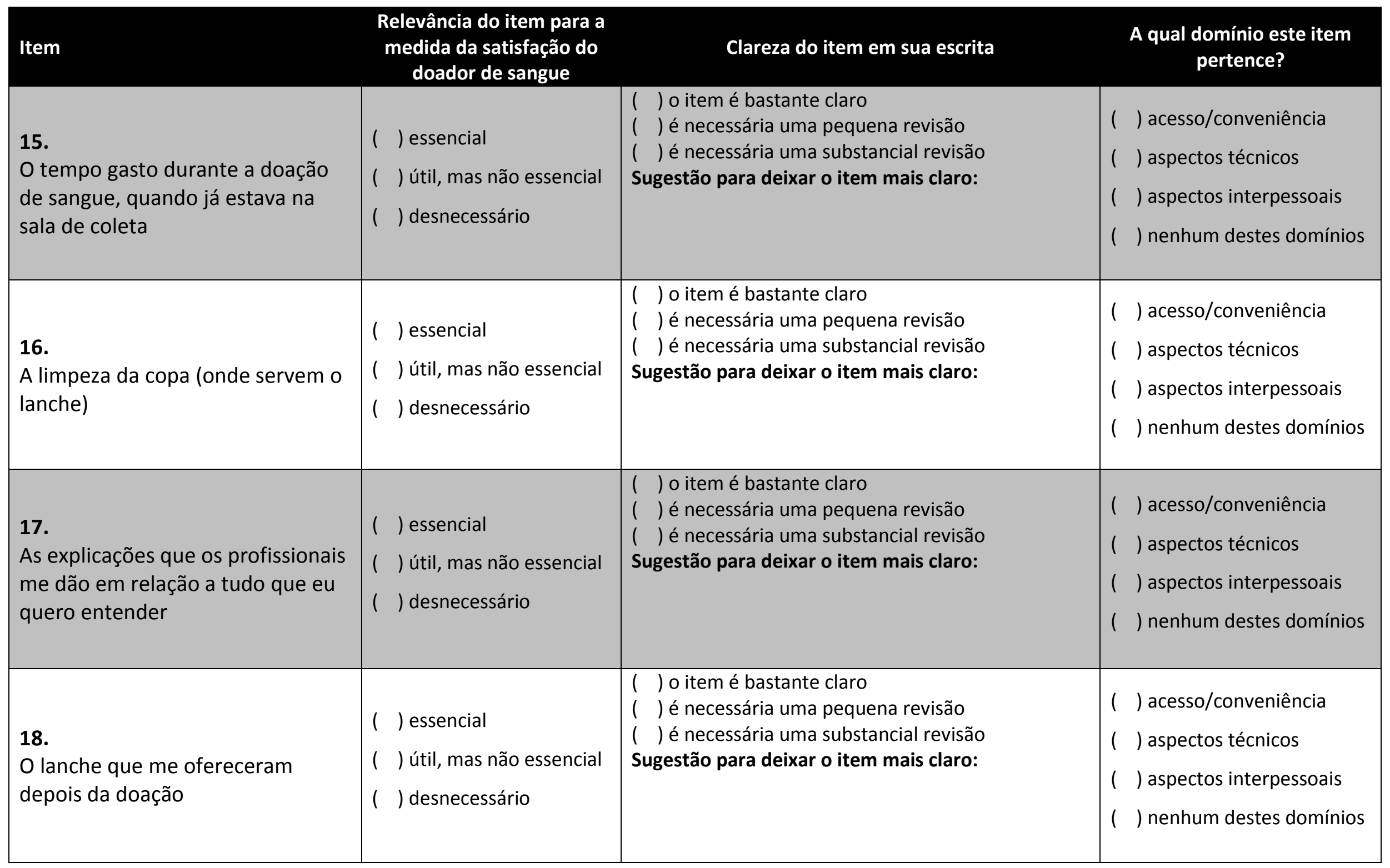




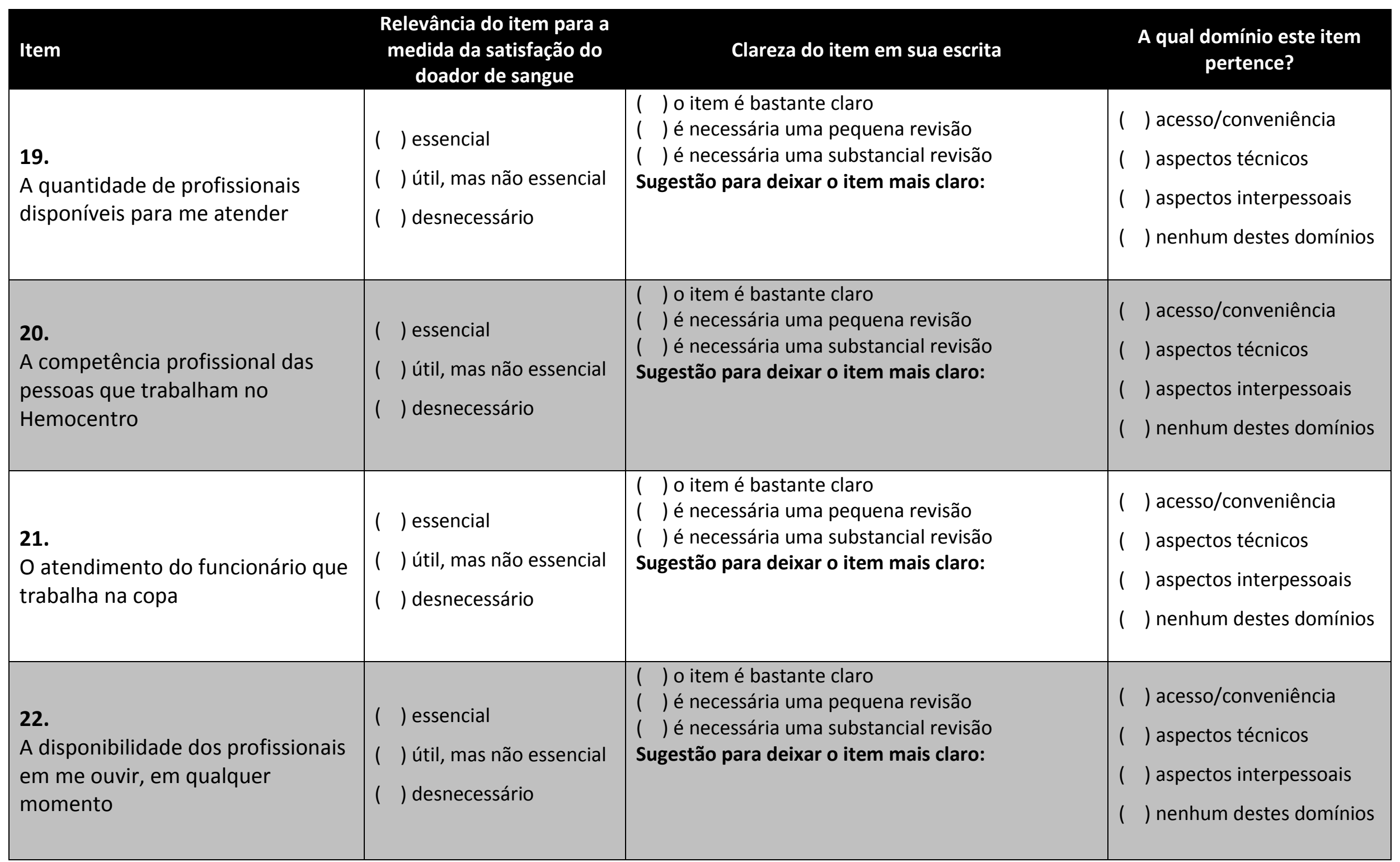




\begin{tabular}{|c|c|c|c|}
\hline Item & $\begin{array}{l}\text { Relevância do item para a } \\
\text { medida da satisfação do } \\
\text { doador de sangue }\end{array}$ & Clareza do item em sua escrita & $\begin{array}{l}\text { A qual domínio este item } \\
\text { pertence? }\end{array}$ \\
\hline $\begin{array}{l}23 . \\
\text { Os horários de atendimento do } \\
\text { Hemocentro ao doador de sangue }\end{array}$ & $\begin{array}{l}\text { ( ) essencial } \\
\text { ( ) útil, mas não essencial } \\
\text { ( ) desnecessário }\end{array}$ & $\begin{array}{l}\text { ( ) o item é bastante claro } \\
\text { ( ) é necessária uma pequena revisão } \\
\text { ( ) é necessária uma substancial revisão } \\
\text { Sugestão para deixar o item mais claro: }\end{array}$ & $\begin{array}{l}(\quad) \text { acesso/conveniência } \\
(\quad) \text { aspectos técnicos } \\
(\quad) \text { aspectos interpessoais } \\
(\quad \text { ) nenhum destes domínios }\end{array}$ \\
\hline $\begin{array}{l}24 . \\
\text { O esforço dos profissionais para eu } \\
\text { me sentir à vontade }\end{array}$ & $\begin{array}{l}\text { ( ) essencial } \\
\text { ( ) útil, mas não essencial } \\
\text { ( ) desnecessário }\end{array}$ & $\begin{array}{l}\text { ( ) o item é bastante claro } \\
\text { ( ) é necessária uma pequena revisão } \\
\text { ( ) é necessária uma substancial revisão } \\
\text { Sugestão para deixar o item mais claro: }\end{array}$ & $\begin{array}{l}\text { ( ) acesso/conveniência } \\
\text { ( ) aspectos técnicos } \\
\text { ( ) aspectos interpessoais } \\
\text { ( ) nenhum destes domínios }\end{array}$ \\
\hline
\end{tabular}

Quais itens você recomenda excluir do instrumento de satisfação do doador de sangue? (identifique os itens que devem ser excluídos por seus respectivos números, ou deixe esta questão em branco se não há itens a serem excluídos). 
Quais outros itens você sugere incluir no instrumento para se obter uma medida da satisfação do doador de sangue? 


\section{Apêndice III}

Termo de Consentimento Livre e Esclarecido (TCLE) para os participantes da Etapa 4 do estudo. 


\section{TERMO DE CONSENTIMENTO LIVRE E ESCLARECIDO}

Título da Pesquisa: "Construção e Validação de um instrumento voltado à satisfação do Doador de Sangue - Uso de Grupos Focais"

Pesquisadores responsáveis: Ana Carolina Garcia Braz Trovão - Enfermeira do Núcleo de Hemoterapia de Franca (COREn 203551), estudante de Doutorado em Saúde na Comunidade da Faculdade de Medicina de Ribeirão Preto, Universidade de São Paulo (USP). Ribeirão Preto, Av. Bandeirantes, 3900, 14049-900, Ribeirão Preto/SP, Telefones (16) 3402-5000 ou (16) 99118-0288. Edson Zangiacomi Martinez - Professor do Departamento de Medicina Social da Faculdade de Medicina de Ribeirão Preto, Universidade de São Paulo (USP), Ribeirão Preto, Av. Bandeirantes, 3900, 14049-900, Ribeirão Preto/SP, Telefone: (16) 3602-2569.

Comitê de Ética em Pesquisa do Hospital das Clínicas da Faculdade de Medicina de Ribeirão Preto (USP): (16) $3602-2228$

Esclarecimentos ao participante da pesquisa: $O(A)$ Senhor(a) está sendo convidado(a) a participar desta pesquisa, através de um questionário, por ter realizado uma doação de sangue. Como é um convite, o(a) senhor(a) não é obrigado(a) a responder a qualquer questão com a qual não se sinta confortável. Sua participação é totalmente voluntária e o(a) senhor(a) pode desistir de participar a qualquer momento, sem qualquer prejuízo para o seu atendimento ou para sua doação de sangue.

Objetivos da pesquisa: A pesquisa pretende construir um instrumento capaz de avaliar a satisfação do doador de sangue. A manutenção dos estoques de sangue no Brasil é um desafio constante nos serviços de hemoterapia e estratégias de fidelização dos doadores e que aumentem a conveniência a novas doações são necessárias. Logo, conhecer o que deixa o doador satisfeito no serviço é fundamental.

Procedimentos: será solicitado ao participante responder a um questionário com perguntas sobre seu atendimento no serviço, além de perguntas sobre sua escolaridade, idade, sexo e quantas vezes já doou sangue. Não haverá procedimentos especiais nesta pesquisa, apenas a aplicação do questionário. 0 tempo estimado para responder a todos os questionários é de aproximadamente 20 minutos. Qualquer dúvida que o(a) senhor(a) tiver será esclarecida a qualquer momento, antes ou depois de aceitar o convite para participar da pesquisa.

Riscos e desconfortos: Considera-se que os riscos ao participar do estudo são mínimos, uma vez que pode haver algum constrangimento durante o preenchimento dos questionários. Lembramos que o(a) senhor(a) não é obrigado a responder a nenhuma pergunta se não quiser. $O$ preenchimento destes questionários não representa qualquer risco de ordem física. Qualquer sujeito de pesquisa tem direito a indenização conforme as leis vigentes no país, caso ocorra dano decorrente de participação na pesquisa.

Benefícios: Suas respostas são muito importantes para o desenvolvimento desta pesquisa. Ao participar o(a) senhor(a) não receberá nenhum benefício direto. Não está prevista nenhuma forma de compensação ou remuneração pela participação no estudo. Entretanto, espera-se que este estudo traga informações importantes para as futuras pesquisas em saúde, dado que ela será bastante importante para entender o que os serviços de hemoterapia podem fazer para melhorar o atendimento ao doador de sangue. 
Confidencialidade da pesquisa: As informações obtidas serão analisadas apenas pelos pesquisadores responsáveis. Futuramente, os resultados serão apresentados em congressos e/ou publicados em revistas científicas, ficando garantido que o(a) senhor(a) não será identificado(a), ou seja, seu nome não será divulgado.

Aceite em participar do estudo: Após estes esclarecimentos, solicito o seu consentimento de forma livre para participar desta pesquisa. Ao assinar este documento, o(a) senhor(a) consente em participar, mas tem a liberdade de sair da pesquisa em qualquer momento. As informações fornecidas pelo(a) senhor(a) são confidenciais e de conhecimento apenas do pesquisador responsável. Os sujeitos da pesquisa não serão identificados em nenhum momento, mesmo quando os resultados desta pesquisa forem divulgados.

A qualquer momento, os pesquisadores responderão a qualquer pergunta ou esclarecimento sobre a pesquisa. Os pesquisadores estarão à sua disposição para isto, no telefone (16) 3402-5000 e celular (16) 99118-0288 (Ana Carolina Garcia Braz Trovão) ou (16)3602.2569 (Prof. Edson Zangiacomi Martinez). Além do contato dos pesquisadores, o Comitê de Ética em Pesquisa (CEP) do Hospital das Clínicas de Ribeirão Preto pode ser contatado pelo telefone (16)3602-2228, em caso de questões éticas relacionadas à pesquisa.

Este documento é elaborado em duas vias, devendo uma ficar o(a) senhor(a) e outra com os pesquisadores responsáveis.

Ribeirão Preto, de de

Pesquisador(a) Responsável

Ribeirão Preto de de

Participante da Pesquisa

Nome do participante: 


\section{Apêndice IV}

As imagens a seguir descrevem como foi feita a coleta dos dados relacionados à Etapa 4 do presente projeto de pesquisa. As fotografias são de autoria da pesquisadora.

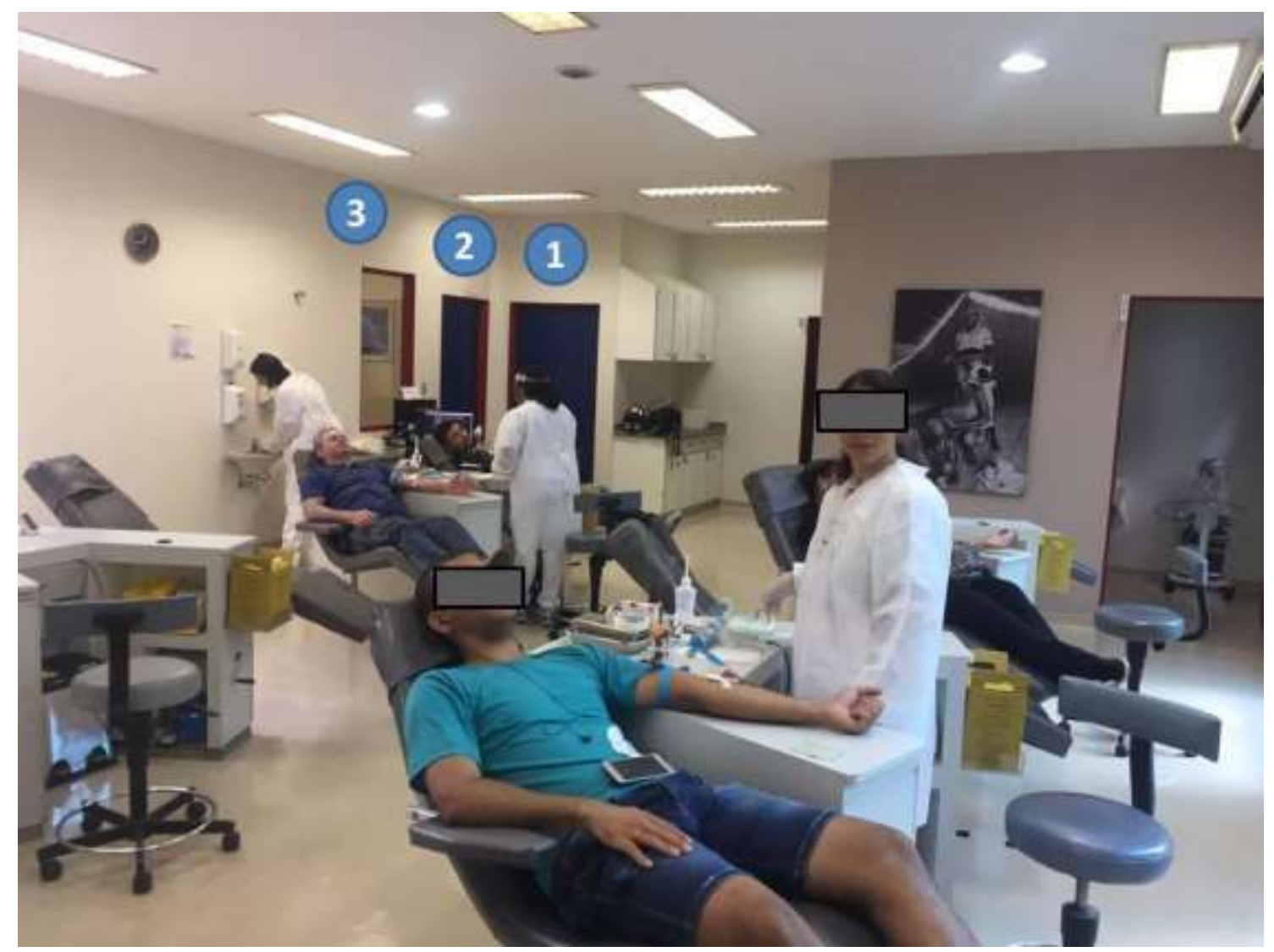

Figura A1. Sala de coleta de sangue.

A Figura A1 mostra a sala de coleta de sangue do Núcleo de Hemoterapia de Franca. Há quatro módulos (cadeiras) e cada flebotomista pode colher sangue simultaneamente de dois doadores. No fundo, há duas portas azuis, identificadas com os números 1 e 2. A porta identificada com o número 1 permite o acesso dos doadores à sala, desde a sala de espera. Logo em frente, há uma mesa com um computador, em que uma funcionária faz o vínculo do crachá do doador com a bolsa de sangue. A porta identificada 
com o número 2 dá acesso à lanchonete. Há uma janela, identificada com o número 3 na imagem da Figura A1, mostrada com mais detalhes na Figura A2.

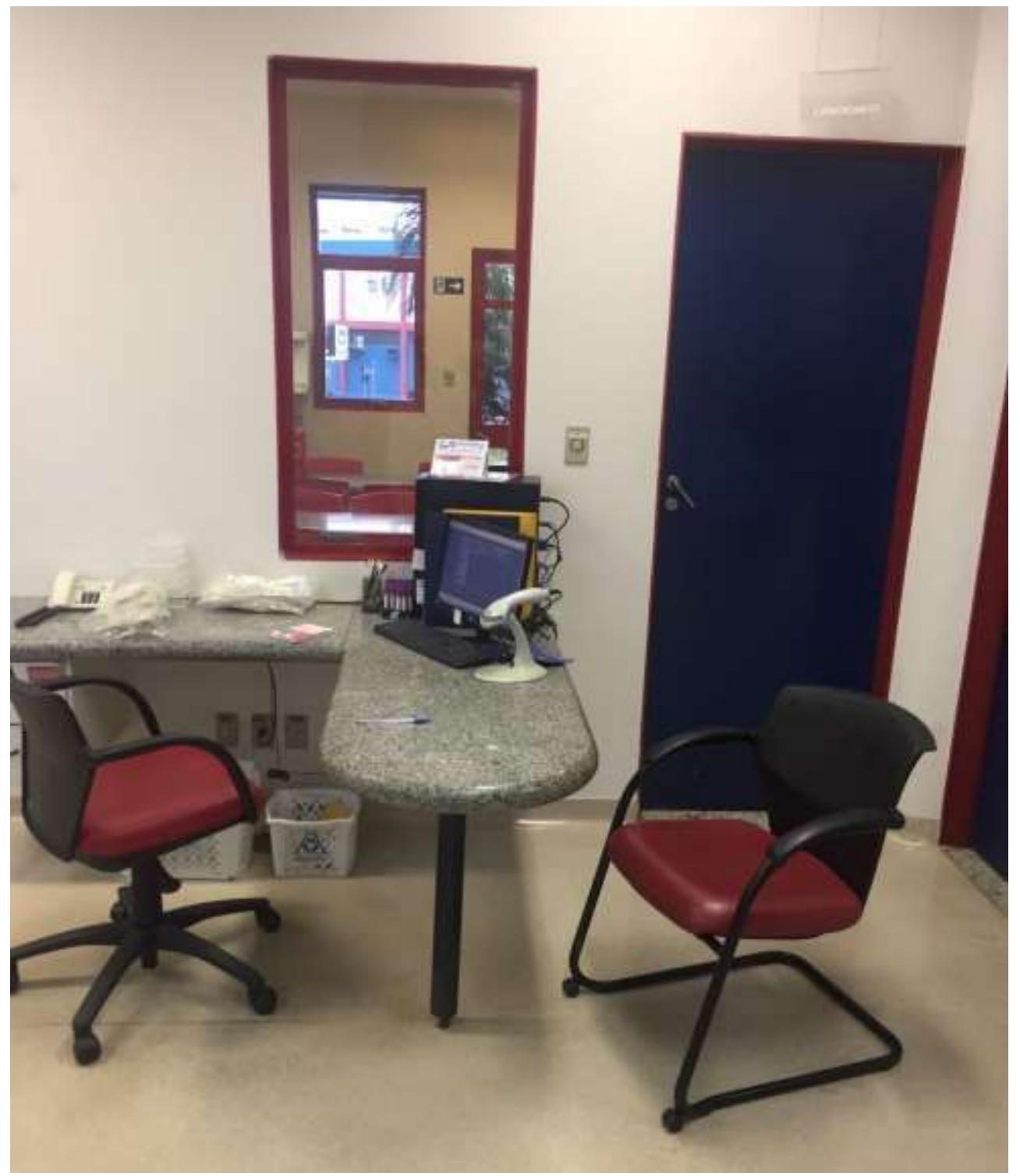

Figura A2. Mesa onde o doador é vinculado com a bolsa de sangue e a janela de permite a visão da lanchonete.

Logo após a doação de sangue, o doador dirige-se à lanchonete, pela porta identificada com o número 2 na Figura A1. A janela de vidro transparente (Figura A2) permite que as flebotomistas presentes na sala de doação observem se o doador, enquanto faz o lanche a ele oferecido, está passando bem, podendo socorrê-lo caso necessário. 
Além disso, na lanchonete, os doadores são orientados da presença de campainhas, que podem acionar se estiverem se sentindo mal ou desejarem algum cuidado. A Figura A3 mostra a lanchonete, sendo que as campainhas estão localizadas na parede logo atrás dos porta-guardanapos vermelhos que estão sobre as mesas.

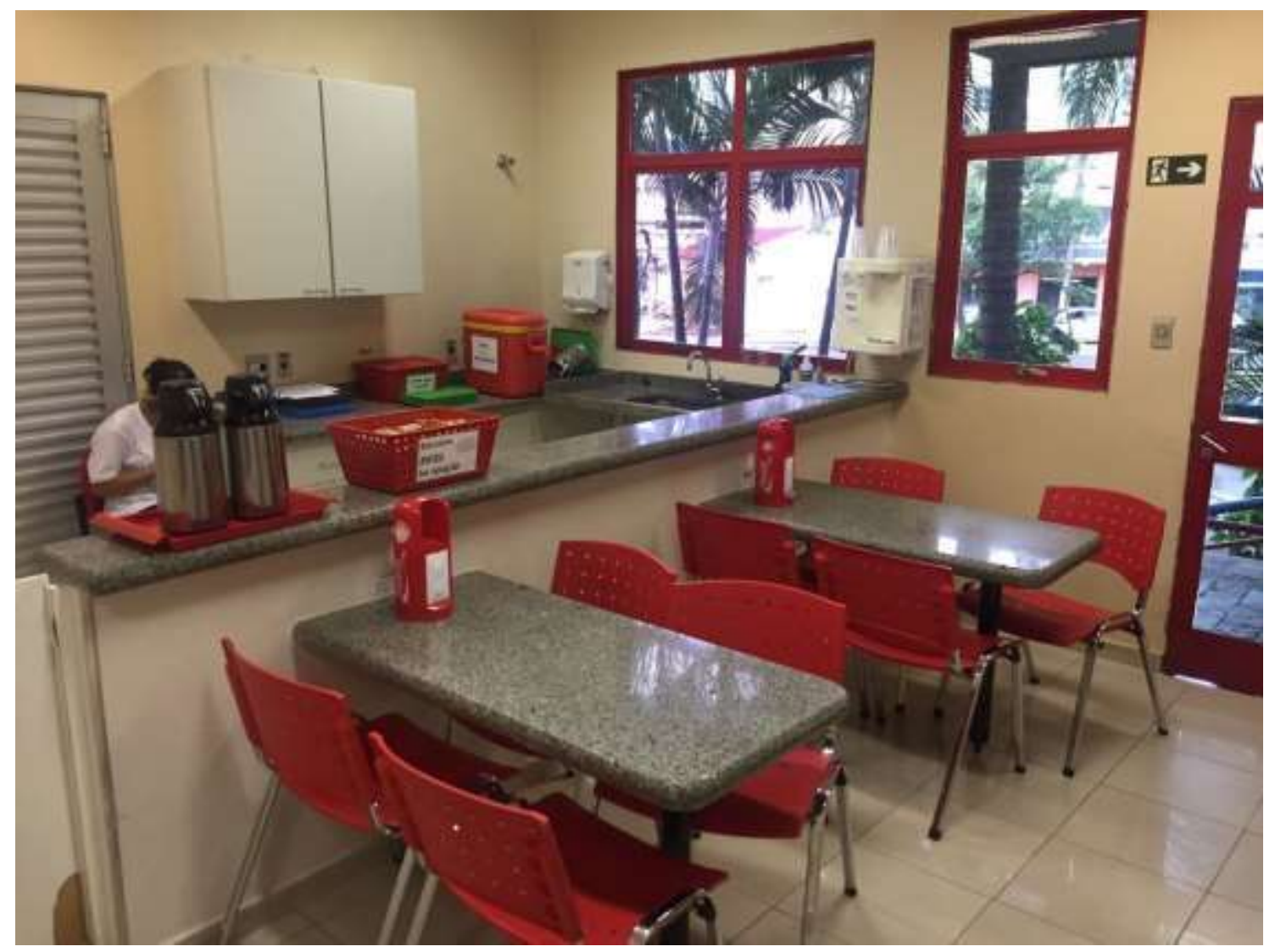

Figura A3. A lanchonete.

Na lanchonete, há também um aviso informando ao doador que ele pode se sentir à vontade de acionar a campainha, caso deseje. Além disso, há uma copeira que fica o tempo todo na lanchonete, orientada a auxiliar o doador a pedir auxílio às flebotomistas. A porta de vidro que aparece no lado direito da Figura A3, indica a saída do doador de sangue. 


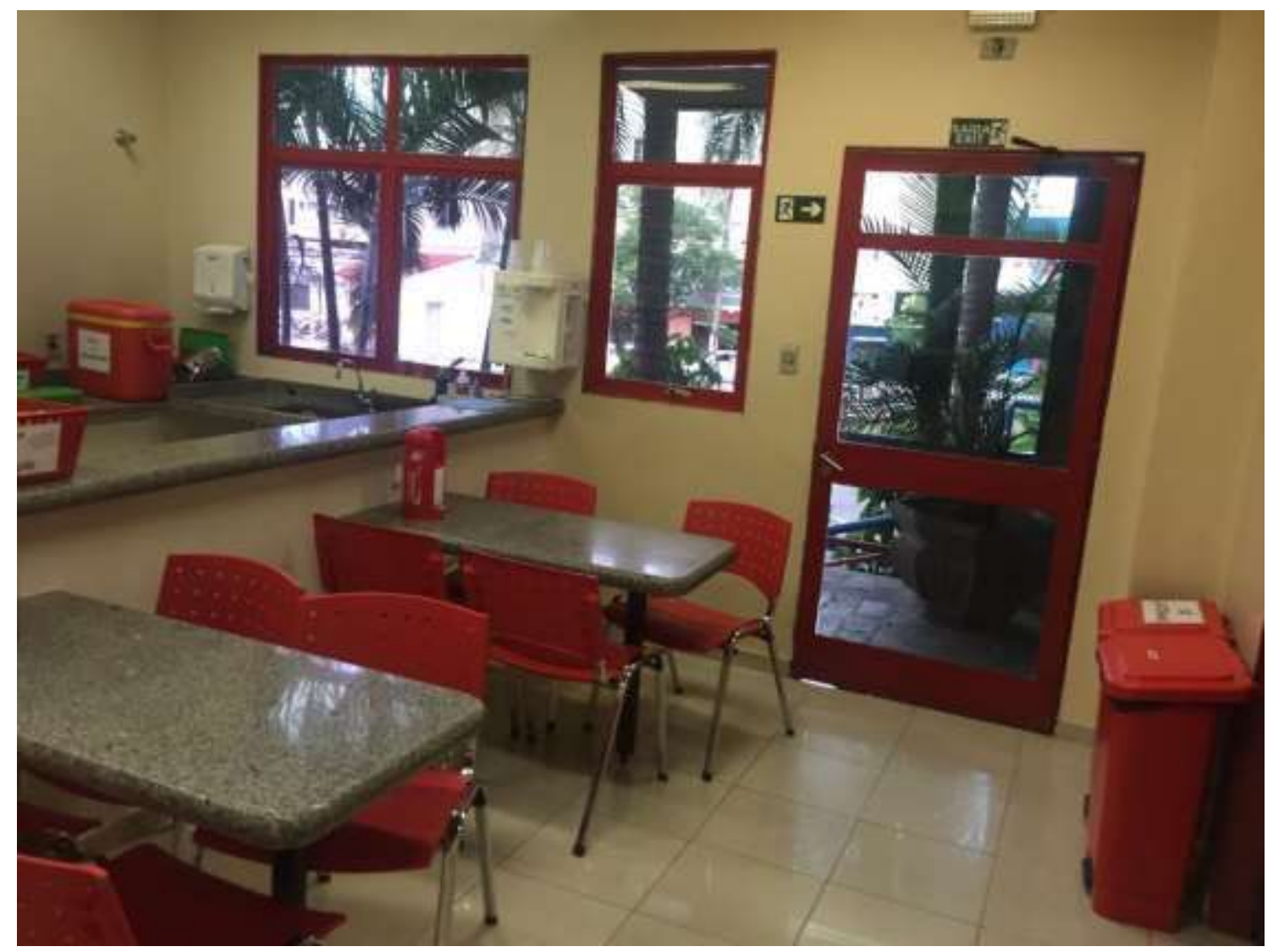

Figura A4. Outra visão da lanchonete.

A Figura A4 mostra outra visão da lanchonete, onde o doador tem à sua disposição o lanche e água. Na rotina de doação de sangue, é nesse ambiente que o doador preenche o questionário de satisfação. Considera-se este ambiente adequado para a coleta dos dados da Etapa 4, dado que é um ambiente tranquilo, reservado, em que o doador pode se sentir confortável e à vontade para preencher o instrumento. 


\section{Apêndice V}

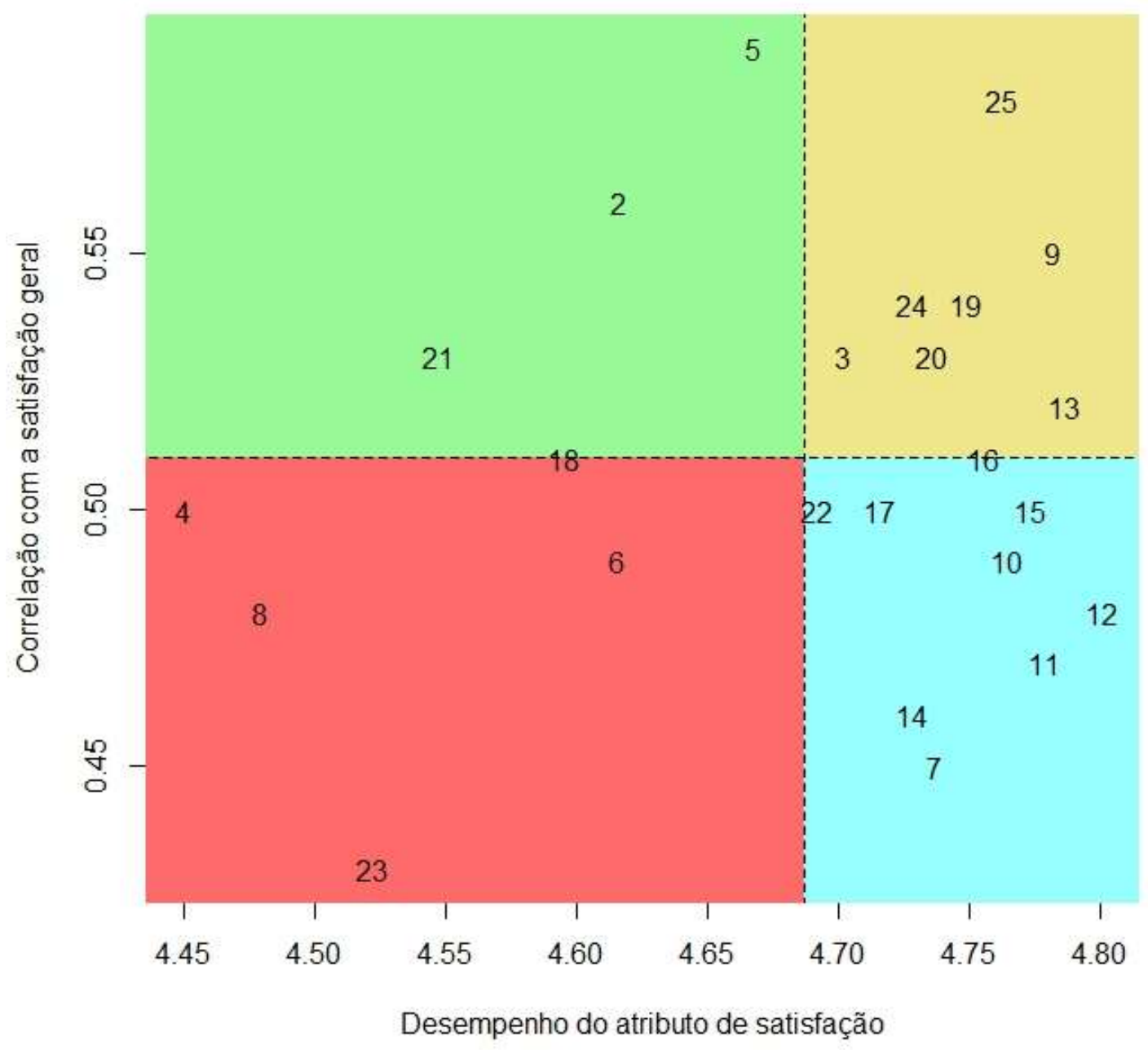

Gráfico desempenho-importância sem considerar o item 1. 


\section{Anexo}

Aprovação do Projeto de Pesquisa e TCLEs pelo Comitê de Ética em Pesquisa do Hospital das Clínicas e Faculdade de Medicina de Ribeirão Preto da Universidade de São Paulo. 


\begin{tabular}{|c|c|}
\hline USP - & $\begin{array}{l}\text { HOSPITAL DAS CLÍNICAS DA } \\
\text { FACULDADE DE MEDICINA DE } \\
\text { RIBEIRÃO PRETO DA USP - }\end{array}$ \\
\hline
\end{tabular}

\section{PARECER CONSUBSTANCIADO DO CEP}

\section{DADOS DO PROJETO DE PESQUISA}

Título da Pesquisa: Construção e Validação de um instrumento voltado à satisfação do Doador de Sangue $¿$ Uso de Grupos Focais

Pesquisador: ANA CAROLINA GARCIA BRAZ TROVÃO

Área Temática:

Versão: 1

CAAE: 61472616.7 .0000 .5440

Instituição Proponente: UNIVERSIDADE DE SAO PAULO

Patrocinador Principal: Financiamento Próprio

\section{DADOS DO PARECER}

Número do Parecer: 1.812 .914

\section{Apresentação do Projeto:}

O presente projeto de pesquisa insere-se na Linha de Pesquisa "Métodos Quantitativos em Saúde" do Programa de Pós-Graduação em Saúde na Comunidade, dentro do Projeto principal "Métodos quantitativos aplicados ao estudo do comportamento de doadores de sangue". A manutenção dos estoques de sangue no país é um desafio constante nos serviços de hemoterapia e estratégias de fidelização dos doadores e que aumentem a conveniência a novas doações são necessárias. Logo, conhecer as expectativas do doador em relação ao atendimento durante a doação, ou seja, o que o deixa satisfeito no serviço, torna-se essencial. Os questionários de satisfação cliente/paciente não são diretamente aplicáveis a doadores, uma vez que não são diretamente aplicáveis a doadores de sangue por uma questão conceitual. O objetivo do presente estudo é construir um instrumento capaz de avaliar a satisfação do doador de sangue, bem como estudar a validade de construto, consistência interna e testar a sensibilidade do instrumento.

\section{Objetivo da Pesquisa:}

Objetivo Primário: O objetivo do presente estudo é construir um instrumento capaz de avaliar a satisfação do doador de sangue no Núcleo de Hemoterapia de FrancaSP.

Além disso, pretende-se estudar a consistência interna, validade de constructo, bem como testar a sensibilidade do instrumento.

Endereço: CAMPUS UNIVERSITÁRIO

Bairro: MONTE ALEGRE CEP: $14.048-900$

UF: SP Município: RIBEIRAO PRETO

Telefone: (16)3602-2228 Fax: (16)3633-1144 E-mail: cep@hcrp.usp.br 


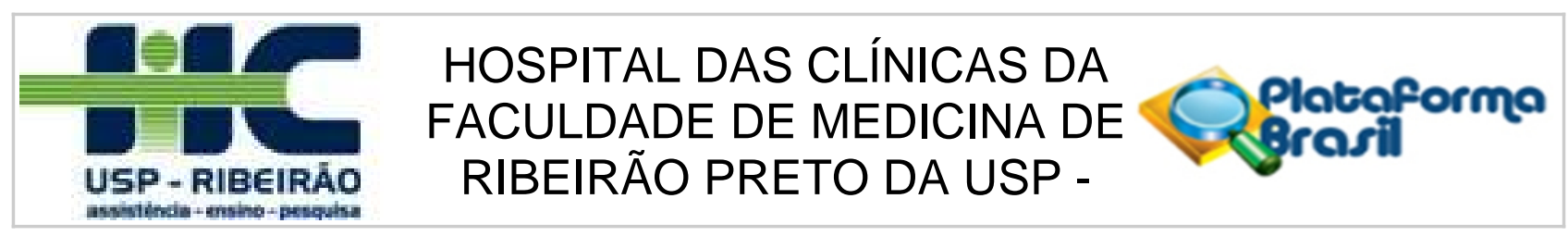

Continuação do Parecer: 1.812 .914

\section{Objetivo Secundário:}

Como objetivos específicos, serão comparados os resultados obtidos no questionário com a idade do doador, sexo, escolaridade, status de doação e sentimentos experimentados durante a doação de sangue.

\section{Avaliação dos Riscos e Benefícios:}

Riscos: Esta pesquisa não submete o doador de sangue a nenhum tipo de risco seja ele físico, moral ou psíquico.

Benefícios: Validar um instrumento de satisfação do doador de sangue que seja próprio a este tipo de clientela dos serviços de saúde, os quais não apenas consomem um serviço prestado, mas também participam do processo por doarem um produto, no caso, biológico.

\section{Comentários e Considerações sobre a Pesquisa:}

Os dados desta pesquisa, os de natureza qualitativa bem como os de natureza quantitativa, serão coletados no Núcleo de Hemoterapia de Franca, pertencente à Fundação Hemocentro de Ribeirão Preto.

O uso do grupo focal neste estudo se aplica pelo fato de que a construção do instrumento de satisfação embasada na perspectiva do doador poderá trazer à tona itens no questionário que até então não foram abordados nos instrumentos de satisfação do doador utilizados no serviço.

Inicialmente, para a construção do questionário de satisfação do doador, serão realizados grupos focais compostos por doadores de sangue

escolhidos aleatoriamente por convite através de contato telefônico. Desse modo, poderão pertencer ao grupo pessoas que doaram apenas uma vez

bem como doadores de repetição. Serão realizados quatro grupos com dez participantes cada um, a fim de não haver perda na qualidade das

informações por ausências inesperadas (MORGAN, 1988). Cada participante receberá as orientações acerca do funcionamento do grupo e assinará

o Termo de Consentimento Livre e Esclarecido. As reuniões serão gravadas e contarão com a presença de dois colaboradores: um relator para

anotações de maior relevância e um observador para compreender os sentimentos, postura e gestos dos participantes com relação aos tópicos

discutidos (KRUEGER, 1988). Ambos os colaboradores são familiarizados com pesquisa qualitativa. As reuniões dos grupos serão realizadas no

Núcleo de Hemoterapia de Franca e terá início as $19 \mathrm{~h}$ e previsão de término para as 20h. Os dados dos grupos focais obtidos através das

Endereço: CAMPUS UNIVERSITÁRIO

$\begin{array}{ll}\text { Bairro: } & \text { MONTE ALEGRE } \\ \text { UF: SP } & \text { Município: }\end{array}$

Telefone: (16)3602-2228 Fax: (16)3633-1144 E-mail: cep@hcrp.usp.br 


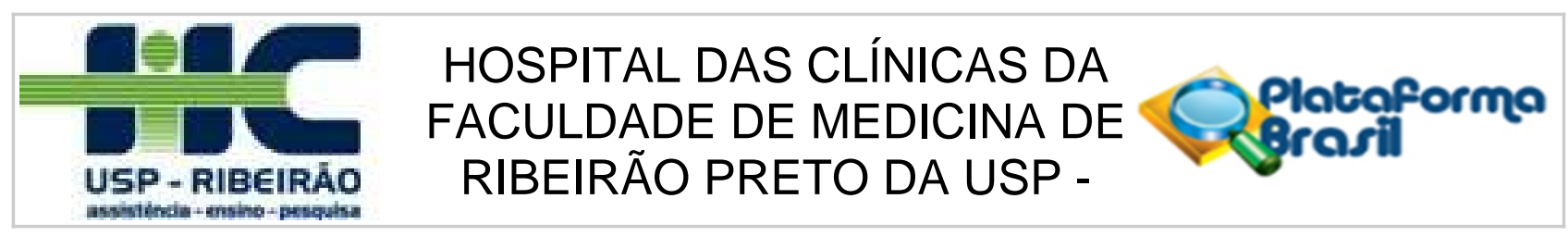

Continuação do Parecer: 1.812 .914

gravações e das anotações de observação são de natureza qualitativa e, portanto, serão transcritos e submetidos à análise de conteúdo (MORGAN,

1988). A partir das transcrições serão criadas as categorias de análise, que neste estudo, serão os itens que irão compor o questionário. Em posse

destes itens, será confeccionado o questionário de satisfação do doador de sangue, o qual será aplicado à amostra de 1000 doadores. $\mathrm{O}$

questionário conterá os itens obtidos a partir dos grupos focais bem como as variáveis do estudo (sexo, idade, escolaridade, status de doação e

pretensão de retorno a novas doações). Após a aplicação dos questionários serão realizadas as análises estatísticas.4.3. População

Estudolndivíduos que doarem sangue na ocasião da coleta de dados, por qualquer motivo, inclusive $p$

\section{Considerações sobre os Termos de apresentação obrigatória:}

Ver Conclusões ou Pendências e Lista de Inadequações

\section{Recomendações:}

Ver Conclusões ou Pendências e Lista de Inadequações

\section{Conclusões ou Pendências e Lista de Inadequações:}

No Projeto de Pesquisa e Plataforma Brasil:

- "As reuniões serão gravadas e contarão com a presença de dois colaboradores: um relator para anotações de maior relevância e um observador para compreender os sentimentos, postura e gestos dos participantes com relação aos tópicos discutido". Incluir quem são os dois colaborados que participarão do estudo;

- "Desse modo, são critérios de inclusão neste estudo as regras que estabelecem a permissão para um indivíduo tornar-se doador de sangue: ter entre 16 (acompanhado pelo responsável legal) e 69 anos..." Solicita-se a elaboração do Termo de Consentimento Livre e Esclarecido para os responsáveis legais dos menores de 18 anos e do Termo de Assentimento para o menor de 18 anos. Segundo a Resolução CNS 466/12, TERMO DE ASSENTIMENTO - documento elaborado em linguagem acessível para os menores ou para os legalmente incapazes, por meio do qual, após os participantes da pesquisa serem devidamente esclarecidos, explicitarão sua anuência em participar da pesquisa, sem prejuízo do consentimento de seus responsáveis legais. Assim, o TCLE deve ser elaborado para os pais/responsáveis e, ao final, deve constar um Termo de Assentimento, onde o estudo é apresentado de forma resumida e acessível à criança ou adolescente. Deve conter os

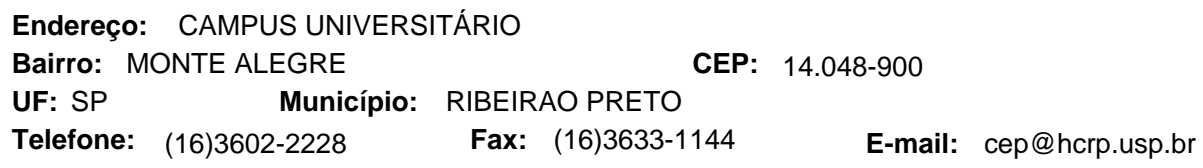




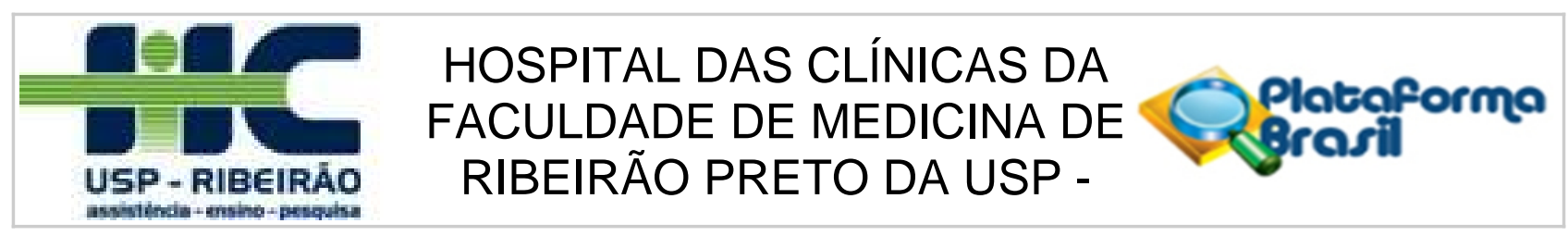

Continuação do Parecer: 1.812 .914

campos para nome, assinatura e data para preenchimento do responsável pela criança, da própria criança, quando possível, e do pesquisador;

- "A coleta de dados será realizada logo após a doação de sangue, na lanchonete, por meio da assinatura do Termo de Consentimento Livre e Esclarecido (TCLE)...". Segundo a resolução vigente, "IV.1 - A etapa inicial do Processo de Consentimento Livre e Esclarecido é a do esclarecimento ao convidado a participar da pesquisa, ocasião em que o pesquisador, ou pessoa por ele delegada e sob sua responsabilidade, deverá: a) buscar o momento, condição e local mais adequados para que o esclarecimento seja efetuado, considerando, para isso, as peculiaridades do convidado a participar da pesquisa e sua PRIVACIDADE;"

- "O TCLE (Anexo II) bem como o instrumento de satisfação serão entregues pelo profissional que recepciona o doador na lanchonete...," Segundo a Resolução CNS 466/12, IV.2 - Superada a etapa inicial de esclarecimento, o pesquisador responsável, ou pessoa por ele delegada, deverá apresentar, ao convidado para participar da pesquisa, ou a seu representante legal, o Termo de Consentimento Livre e Esclarecido para que seja lido e compreendido, antes da concessão do seu consentimento livre e esclarecido." Desse modo, solicita-se esclarecimento quanto ao recrutamento e aplicação do TCLE, de que forma ocorrerá o recrutamento e aplicação dos TCLEs e quem as realizará. Ressaltamos que a pesquisa é de responsabilidade do pesquisador responsável mesmo que ele delegue a outra pessoa devidamente treinada e participante como integrante da pesquisa;

- Incluir a lista da equipe de pesquisa com nome de cada envolvido e sua respectiva função na pesquisa. Os mesmos devem ser incluídos no projeto de pesquisa e na Plataforma Brasil;

- Segundo a Resolução 466/12 toda pesquisa que envolve seres humanos apresenta riscos, mesmo que mínimos. Incluir os riscos ou desconfortos para o participante da pesquisa em responder aos questionários e incluir a possível quebra de sigilo ou confidencialidade dos dados;

Nos TCLES:

- Rever os desconfortos e riscos possíveis, e apresentação das providências e cautelas a serem empregadas para evitar e/ou reduzir efeitos e condições adversas que possam causar dano, considerando características e contexto do participante da pesquisa;

- Informar o tempo da participação dos sujeitos na pesquisa;

- -Se há ou não formas de ressarcimento das despesas decorrentes da participação na pesquisa (exemplo: transporte e alimentação);

-Formas de indenização diante de eventuais danos decorrentes da pesquisa. Deve-se garantir aos

Endereço: CAMPUS UNIVERSITÁRIO

Bairro: MONTE ALEGRE CEP: $14.048-900$

UF: SP Município: RIBEIRAO PRETO

Telefone: (16)3602-2228 Fax: (16)3633-1144 E-mail: cep@hcrp.usp.br 


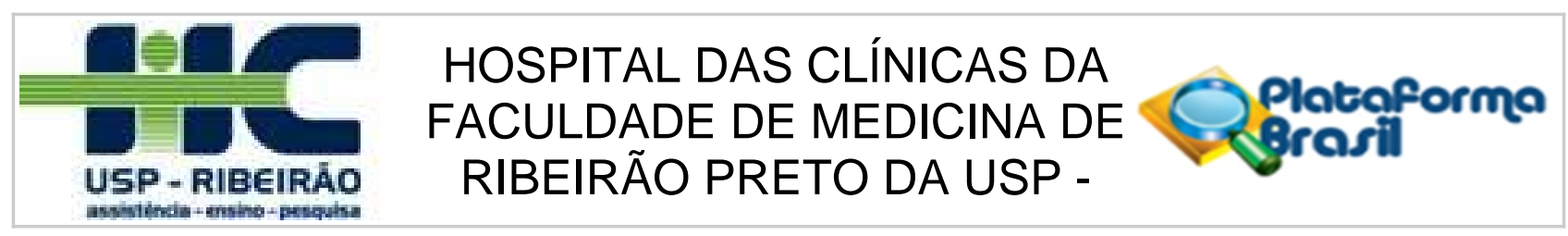

Continuação do Parecer: 1.812 .914

participantes da pesquisa o direito a indenização. Dessa forma, recomenda-se que seja explicitado o direito de indenização do participante de pesquisa por agravo imediato ou posterior, direto ou indireto, ao indivíduo decorrente da pesquisa. Caso o estudo seja contemplado por apólice de seguro, anexar cópia da mesma; caso não se disponha de seguro, no texto do TCLE deve estar claro que o sujeito de pesquisa tem direito a indenização conforme as leis vigentes no país, caso ocorra dano decorrente de participação na pesquisa;

- Retirar o trcho "Eu, ᄀר por meio deste Termo de Consentimento Livre e Esclarecido, manifesto ser de minha vontade participar desta pesquisa. Tenho conhecimento da justificativa, objetivos, procedimentos a serem realizados, bem como da possibilidade de receber esclarecimentos sobre o que eu tiver dúvida sobre a pesquisa. Será mantido sigilo (segredo) quanto da minha identificação para respeitar minha privacidade."

-Inserir página;

-Ao final do documento devem constar apenas campos distintos, para preenchimento do nome, assinatura e data do pesquisador, e campos distintos para preenchimento do nome, assinatura e data do participante da pesquisa ou responsável legal. Exemplo:

Nome do participante: assinatura: data:

Nome do pesquisador: assinatura: data:

- Se necessário, configurar o TCLE de forma que os locais destinados as assinaturas do sujeito e do pesquisador não fiquem em folhas separadas (desmembradas) do corpo do texto. Diante do exposto e à luz da Resolução CNS 466/2012, o projeto de pesquisa encontra-se em pendência.

Solicita-se que as respostas sejam enviadas através de uma carta constando, de forma ordenada, as respostas dos itens de consideração deste parecer, destacando as alterações realizadas e as possíveis localizações no Projeto e no Termo de Consentimento Livre e Esclarecido (TCLE).

O Projeto e TCLE contendo as modificações solicitadas devem ser apresentados na forma de novos documentos contendo nos rodapés de cada página a identificação (número) da nova versão, com a respectiva data de modificação dos referidos documentos.

Ao adicionar as novas versões, favor não excluir os documentos já anexados.

\section{Considerações Finais a critério do CEP:}

Favor verificar as considerações constantes no Parecer Consubstanciado do CEP.

De acordo com a Resolução CNS no 466 de 2012 e a Norma Operacional no 001 de 2013 do CNS, as Pendências devem ser respondidas pelo pesquisador responsável no prazo de 60 dias, a partir

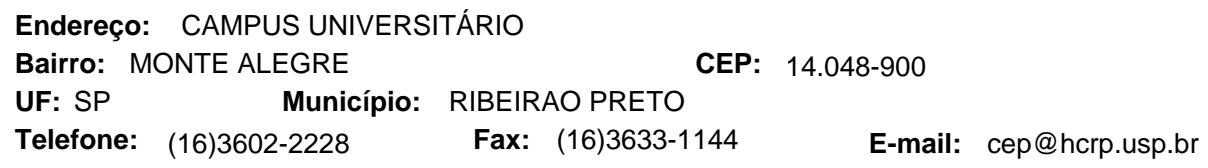




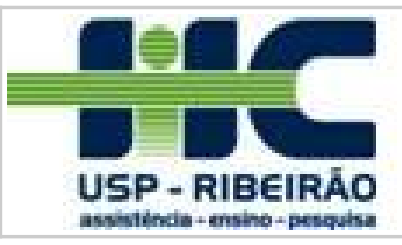

\section{HOSPITAL DAS CLÍNICAS DA FACULDADE DE MEDICINA DE RIBEIRÃO PRETO DA USP -}

Continuação do Parecer: 1.812.914

da data de emissão desse Parecer pelo CEP. Após esse prazo o projeto será arquivado.

Este parecer foi elaborado baseado nos documentos abaixo relacionados:

\begin{tabular}{|c|c|c|c|c|}
\hline Tipo Documento & Arquivo & Postagem & Autor & Situação \\
\hline $\begin{array}{l}\text { Informações Básicas } \\
\text { do Projeto }\end{array}$ & $\begin{array}{l}\text { PB_INFORMAÇÖES_BÁSICAS_DO_P } \\
\text { ROJETO 774847.pdf }\end{array}$ & $\begin{array}{c}28 / 10 / 2016 \\
16: 52: 35\end{array}$ & & Aceito \\
\hline Cronograma & CRONOGRAMA.doc & $\begin{array}{c}28 / 10 / 2016 \\
16: 51: 16\end{array}$ & $\begin{array}{l}\text { ANA CAROLINA } \\
\text { GARCIA BRAZ } \\
\text { TROVÃO }\end{array}$ & Aceito \\
\hline Outros & HEMO.pdf & $\begin{array}{c}28 / 10 / 2016 \\
16: 45: 26\end{array}$ & $\begin{array}{l}\text { ANA CAROLINA } \\
\text { GARCIA BRAZ } \\
\text { TROVÃO }\end{array}$ & Aceito \\
\hline $\begin{array}{l}\text { Declaração de } \\
\text { Instituição e } \\
\text { Infraestrutura }\end{array}$ & UCP.pdf & $\begin{array}{c}06 / 10 / 2016 \\
07: 32: 56\end{array}$ & $\begin{array}{l}\text { ANA CAROLINA } \\
\text { GARCIA BRAZ } \\
\text { TROVÃO }\end{array}$ & Aceito \\
\hline Folha de Rosto & Folha_de_rosto.doc & $\begin{array}{c}02 / 09 / 2016 \\
17: 32: 03\end{array}$ & $\begin{array}{l}\text { ANA CAROLINA } \\
\text { GARCIA BRAZ } \\
\text { TROVÃO }\end{array}$ & Aceito \\
\hline $\begin{array}{l}\text { Projeto Detalhado / } \\
\text { Brochura } \\
\text { Investigador }\end{array}$ & Projeto_de_Doutorado.doc & $\begin{array}{l}02 / 09 / 2016 \\
17: 21: 45\end{array}$ & $\begin{array}{l}\text { ANA CAROLINA } \\
\text { GARCIA BRAZ } \\
\text { TROVÃO }\end{array}$ & Aceito \\
\hline $\begin{array}{l}\text { TCLE / Termos de } \\
\text { Assentimento / } \\
\text { Justificativa de } \\
\text { Ausência }\end{array}$ & TCLE2.doc & $\begin{array}{l}02 / 09 / 2016 \\
17: 17: 42\end{array}$ & $\begin{array}{l}\text { ANA CAROLINA } \\
\text { GARCIA BRAZ } \\
\text { TROVÃO }\end{array}$ & Aceito \\
\hline $\begin{array}{l}\text { TCLE / Termos de } \\
\text { Assentimento / } \\
\text { Justificativa de } \\
\text { Ausência }\end{array}$ & TCLE1.doc & $\begin{array}{c}02 / 09 / 2016 \\
17: 17: 11\end{array}$ & $\begin{array}{l}\text { ANA CAROLINA } \\
\text { GARCIA BRAZ } \\
\text { TROVÃO }\end{array}$ & Aceito \\
\hline
\end{tabular}

\section{Situação do Parecer:}

Pendente

\section{Necessita Apreciação da CONEP:}

Não

RIBEIRAO PRETO, 09 de Novembro de 2016

Assinado por:
MARCIA GUIMARÃES VILLANOVA
(Coordenador)

Endereço: CAMPUS UNIVERSITÁRIO

Bairro: MONTE ALEGRE

UF: SP Município: RIBEIRAO PRETO

Telefone: (16)3602-2228 Fax: (16)3633-1144 E-mail: cep@hcrp.usp.br 